\title{
Somatisation in general practice : clinical assessment and the effectiveness of disclosing emotionally important events
}

Citation for published version (APA):

Schilte, B. (2001). Somatisation in general practice : clinical assessment and the effectiveness of disclosing emotionally important events. [Doctoral Thesis, Maastricht University]. Datawyse / Universitaire Pers Maastricht. https://doi.org/10.26481/dis.20010706bs

Document status and date:

Published: 01/01/2001

DOI:

10.26481/dis.20010706bs

Document Version:

Publisher's PDF, also known as Version of record

Please check the document version of this publication:

- A submitted manuscript is the version of the article upon submission and before peer-review. There can be important differences between the submitted version and the official published version of record.

People interested in the research are advised to contact the author for the final version of the publication, or visit the DOI to the publisher's website.

- The final author version and the galley proof are versions of the publication after peer review.

- The final published version features the final layout of the paper including the volume, issue and page numbers.

Link to publication

\footnotetext{
General rights rights.

- You may freely distribute the URL identifying the publication in the public portal. please follow below link for the End User Agreement:

www.umlib.nl/taverne-license

Take down policy

If you believe that this document breaches copyright please contact us at:

repository@maastrichtuniversity.nl

providing details and we will investigate your claim.
}

Copyright and moral rights for the publications made accessible in the public portal are retained by the authors and/or other copyright owners and it is a condition of accessing publications that users recognise and abide by the legal requirements associated with these

- Users may download and print one copy of any publication from the public portal for the purpose of private study or research.

- You may not further distribute the material or use it for any profit-making activity or commercial gain

If the publication is distributed under the terms of Article $25 \mathrm{fa}$ of the Dutch Copyright Act, indicated by the "Taverne" license above, 
Somatisation in general practice 
The study presented in this thesis was conducted at the Research Institute for Extramural and Transmural Health Care (ExTra), which participates in the Netherlands School of Primary Care Research (CaRe), acknowledged in 1995 by the Royal Dutch Academy of Science (KNAW).

ISBN 9090148868

(C) Steinkopff Verlag, Darmstadt, Germany: chapter three

(C) Taylor \& Francis, Oxfordshire, England: chapter four

(C) BMJ, London, England: chapter six

(C) A.F. Schilte: other chapters

All rights reserved. No part of this book may be reproduced or transmitted in any form or by any means, electronic or mechanical, including photocopying, recording, or by any information storage and retrieval system without written permission from the publisher, except for the inclusion of brief quotations in a review.

Book preparation, cover design and printing: Datawyse / Universitare Pers Maastricht 


\section{Somatisation in general practice}

Clinical assessment and the effectiveness of disclosing emotionally important events

\section{Proefschrift}

ter verkrijging van de graad van doctor aan de Universiteit Maastricht, op gezag van de Rector Magnificus, Prof. dr. A.C. Nieuwenhuijzen Kruseman, volgens het besluit van het College van Decanen, in het openbaar te verdedigen op vrijdag 6 juli om 16.00 uur

door

\section{Bert Schilte}


Promotor

Prof. dr. J.A. Knottnerus

Co-promotores

Dr. P.J.M. Portegijs

Dr. H.E. van der Horst (Vrije Universiteit Amsterdam)

Beoordelingscommissie

Prof. dr. P.G. Knipschild (voorzitter)

Prof. mr. dr. R.P.T.M. Grol

Prof. dr. M. de Haan (Vrije Universiteit Amsterdam)

Prof. dr. V.J. Pop (Katholieke Universiteit Brabant)

Prof. dr. M.W. de Vries

The study presented in this thesis was supported by grant no. 940-33-016 from the Netherlands Organisation for Scientific Research, council for medical and health research (NWO). 
Paranimfen

Pascal Meijer

Rien Heijnen 


\section{Contents}

1. Introduction 9

2. Workload determinants for general practitioners 13

3. Somatisation in primary care: clinical judgement and standardised measurement compared 27

4. Indicators of childhood adversity in somatisation in general practice 41

5. A disclosure intervention for general practice patients with somatisation: an illustration with three case histories 53

6. Is disclosure of emotionally important events effective in somatisation in primary care? A randomised controlled trial 63

7 Predictors of prognosis in long-term somatisation in primary care, the role of stress 79

8. General discussion 91

9. Summary 99

10. Samenvatting 103

Appendix A: General Practitioners participating in the project 109

Appendix B: Patient questionnaire on main outcome measures 110

Appendix C: Study profile: patient population per chapter 114

Dankwoord 115

Curriculum vitae 119 

Chapter 1

Introduction 


\section{BACKGROUND}

Typical traits of general practice are the keeping of detailed medical record of patients and their families, somatic and psychosocial problems without pre-selection, a personal and longitudinal relationship between doctor and patient, and easy accessibility of care. The combination of these aspects puts general practitioners (GPs) in a unique position to help patients with physical symptoms unexplained by somatic disease. ${ }^{1}$ For specific unexplained symptoms and certain common psychiatric disorders, consensus among GPs has been reached and training packages have been developed. ${ }^{2,3}$ However, for somatisation as a more general problem not limited to one functional syndrome, little expertise exists. Meanwhile, GPs consider somatisers as difficult or even frustrating patients and often get caught up in somatisation circles. ${ }^{4-6}$ Important issues, such as the identification and diagnosis, the effectiveness of treatment, and the natural course of somatisation, remain to be studied. ${ }^{7,8}$ In this thesis we will address several of these topics.

Portegijs' exploratory study on somatisation in frequent attenders of general practice ${ }^{5}$ has brought forward Lipowski's definition of somatisation ${ }^{9}$ and Escobar's Somatic Symptom Index (SSI) ${ }^{10}$ as relevant, measurable, and valid concepts of somatisation in general practice. Escobar's SSI is derived from the DSM-III-R (Diagnostic Statistical Manual of Psychiatric Disorders, $3^{\text {rd }}$ revised edition) list of somatisation symptoms, instead of the more recent DSM-IV. Portegijs also found somatisation to be related to unfavourable youth experiences, especially to deprivation of parental care. In his study somatisation traits of patients became evident especially under stressful circumstances, resulting in increased risk of depression.

A number of patients in Portegijs' descriptive study reported that the interviews on youth problems, life events, health problems, depression and anxiety had helped them a lot. The next step was a study in which this disclosure aspect was tested as intervention in somatising patients in general practice. A number of studies with promising results have been published recently on so-called disclosure interventions. ${ }^{11}$ These disclosure interventions consisted of assignments to write or talk about traumatic and emotionally upsetting events. The disclosure released stress, improved the function of the immune and autonomic nervous systems, improved subjective health, and diminished the use of health care services, mostly in healthy subjects. ${ }^{11,12}$ No reports have been published on the effect of disclosure on somatising patients, although somatisers seem to have greater room for improvement than healthy individuals. Most patients are familiar with disclosure of emotions in normal social interaction, sometimes through their religion (confession) or as an aspect of the relationship with their GP or other health care providers. Disclosure is therefore a promising 
and acceptable therapeutic method for somatisation in primary care. Therefore the present disclosure intervention study was initiated.

Another research group (EMGO, Amsterdam) prepared an intervention study on the effectiveness of reattribution in somatising patients. Cooperation between the research groups in Maastricht and Amsterdam resulted in a double study on two different interventions for patients with somatisation in general practice.$^{13}$ Both projects used identical definitions, operationalisations, selection criteria, research instruments, had a synchronic time-scheme, and made use of each others' data. The collaboration between the two research groups is also reflected in combined authorship for the publication of articles.

\section{OUTLINE OF THIS THESIS}

An important criterion to identify somatising patients is frequency of attendance. For this reason we studied the distribution and determinants of attendance rates of patients in general practice (second chapter). For this chapter, data from a study on multimorbidity in general practice were used. ${ }^{14}$ In daily practice, GPs rely on their clinical judgement instead of using standardised questionnaires to determine somatisation. We compared the clinical judgement and standardised measurement of somatisation in chapter three, against the background of other important variables. As a next step we analysed the history of somatising patients, with a special focus on patients who had a problematic childhood in chapter four. In chapter five a disclosure intervention for somatisation in general practice is introduced and illustrated. The effectiveness of this disclosure intervention is tested in a randomised controlled trial in 161 general practice somatisers in chapter six. The natural course of somatisation and predictors of prognosis are analysed in chapter seven. Finally, chapter eight provides a general discussion of the methods, results and conclusions of the earlier chapters and chapters nine and ten summarise the contents of this thesis in English and Dutch. Appendix A lists the participating general practitioners, appendix $\mathrm{B}$ the questions about the main outcome measures, and appendix $\mathrm{C}$ the profile of patients in all chapters. 


\section{REFERENCES}

1. Gallo JJ, Coyne JC. The challenge of depression in late life. JAMA 2000;284: $1570-1572$.

2. van der Horst $\mathrm{H}$, Meijer J, Muris J, et al. NHG-standaard prikkelbare darm syndroom (irritable bowel syndrome). Huisarts en Wetenschap 2001;44:58-65.

3. JennerJA, van der Meer K, van Os TWDP, van den Brink RHS, Tiemens BG, Ormel $\mathrm{J}$. Psychosociale klachten in de huisartspraktijk, een trainingsprogramma voor huisartsen (INSTEL). Groningen: Van Gorcum, Assen, 1995.

4. Mayou R, Sharpe M. Patients whom doctors find difficult to help. An important and neglected problem. Psychosomatics 1995;36:323-325.

5. Portegijs PJM. Somatization in frequent attenders of general practice. Ph.D. thesis: University of Maastricht, 1996.

6. Grol R. Huisarts en somatische fixatie. Utrecht: Bohn, Scheltema \& Holkema, 1983.

7. Fink P. Somatization-beyond symptom count. J Psychosom Res 1996;40:7-10.

8. Rief W, Hiller W. Somatization-future perspectives on a common phenomenon. $J$ Psychosom Res 1998;44:529-536.

9. Lipowski ZJ. Somatization: The concept and its clinical application. Am J Psychiatry 1988;145:1358-1368.

10. Escobar JI, Rubio-Stipec M, Canino G, Karno M. Somatic symptom index (SSI): a new and abridged somatization construct. Prevalence and epidemiological correlates in two large community samples. J Nerv Ment Dis 1989;177:140-146.

11. Smyth JM. Written emotional expression: effect sizes, outcome types, and moderating variables. J Cons Clin Psychol 1998;66:174-184.

12. Pennebaker JW, Susman JR. Disclosure of traumas and psychosomatic processes. Soc Sci Med 1988;26:327-332.

13. NWO. Effectiveness of two interventions for somatization in general practice: A randomized controlled trial. Den Haag: Research program chronic diseases: neurological and psychiatric disorders; grant number 940-33-016, 1996.

14. van den Akker M. Multimorbidity in a general practice population, prevalence, incidence and determinants of multiple pathology. Ph.D. thesis: University of Maastricht, 1999. 
Chapter 2

Workload determinants for general practitioners

AF Schilte, M van den Akker, and H. Vlek

Submitted for publication 


\section{ABSTRACT}

Background The present study was undertaken to assess the distribution of workload in general practice in the Netherlands, and to assess the contribution of health problems and patient visiting patterns in previous years, to the workload of GPs.

Methods Data on consultation rates, relevant health problems, and sociodemographic variables were collected in a sample of 2957 subjects aged 20 and older, in nine general practices.

Results One-fifth of the patients accounted for 50\% of the GP's time, and half consumed $80 \%$. This distribution is similar to reports from other countries. In a regression model, sociodemographic variables explained $9 \%$ of the variance in consultation rates, health problems another $11 \%$, and attendance in earlier years an additional 11\%. Differences between practices were of marginal importance.

Conclusion Two-thirds of the variance in patient attendance remained unexplained by the variables under study. Further research on the role of psychosocial factors on patient attendance is recommended. 


\section{INTRODUCTION}

Patient consultation rates are directly related to general practitioners' workload, as well as to the use of health care services in general. ${ }^{1,2}$ General practitioners (GPs) generally have overfull agendas, and implementation of new quality-of-care programmes will put further demands on their time. ${ }^{3}$ Understanding the factors that contribute to the daily workload is a first step, when GPs want to manage and control their agendas more effectively. ${ }^{1,4,5}$

First, the socioeconomic and demographic setting of the practice colours the workload of GPs. Distribution of age, sex, education, work-status, and urban or rural setting have to be taken into account. ${ }^{1,2,4-9}$ Secondly, chronic disease (somatic or psychiatric) is a main long-term determinant of high attendance rates. ${ }^{2,7,10}$ Non-chronic disease will probably increase attendance for a shorter period of time. In the third place, patient-related psychosocial factors are associated with consultation rates. Examples are elevated levels of stress, recent life events or crisis, long-lasting social difficulties, and traumatic experiences in childhood. ${ }^{7,10-13}$ A good social support network may protect against frequent doctor visits. ${ }^{14,15}$ Additionally, patient charactertraits have a more lasting influence on consultation rates: personality, style of coping, locus of control, illness behaviour, and somatisation. 6,7,15-22 Last but not least, doctor-specific factors play a role, such as GP consultation styles, training, involvement in preventive tasks, and the quality of communication between physicians and patients. ${ }^{23-28}$

These factors often interrelate and overlap in their contribution to workload of GPs, and the weight of individual factors on workload can only be assessed by means of a regression model. So far a few studies have been carried out, using multivariate regression, in the fourth national morbidity survey of UK (United Kingdom) general practices, in which sociodemographic variables and permanent disease were found to explain between $2 \%$ and $8 \%$ of the variance in consultation rates. ${ }^{1,5,29}$ The present study was undertaken to assess how much disease and patient visiting patterns in previous years contribute to workload of GPs in the Netherlands, taking into account sociodemographic variables and differences between practices.

\section{METHODS}

\section{DATABASE}

Subjects were sampled from the Family Practice Registration Network (RegistratieNet Huisartspraktijken, RNH). The RNH is a continuous and computerised database in which 55 general practitioners, working in 22 different practices in the south of the Netherlands, are participating. ${ }^{30}$ In the RNH all rele- 
vant health problems are registered; these are problems which are permanent, chronic, recurrent, or with lasting consequences in terms of functional status or prognosis. Problems are coded according to the International Classification of Primary Care (ICPC), using the criteria for diagnosis of the International Classification of Health Problems in Primary Care (ICHPPC-2). ${ }^{31,32}$ In addition, the database contains background information on sociodemographic characteristics. The quality of the data in the RNH is maintained by instruction and training sessions, regional consensus groups, quality control experiments, and an automated thesaurus with automated checking for erroneous or missing entries. Reliability and completeness have been shown by comparisons between RNH's cancer data and the data of the regional cancer registry, and between RNH's epilepsy data and the Maastricht epilepsy case register. ${ }^{33}$

For this study only registered diagnostic ICPC codes (70-99) were used. A selection of 35 ICPC codes of prevalent chronic disease conditions, such as diabetes mellitus, emphysema, multiple sclerosis, or cardio-vascular disease, was analysed separately.

\section{POPULATION}

We used data on 2957 subjects, aged 20 years and older, from nine general practices in the registration network, who had participated in an earlier large register-based study on psychological, sociological, and demographic determinants of multimorbidity. ${ }^{34}$ The 9 practices were comparable with the total group of 22 (and with other practices in the region) on the variables: single/group practice and urban/non-urban practice. The subjects were randomly sampled from three strata: subjects with no new morbidity on their problem list during the last three years (1992-1994), subjects with one new health problem on their problem list, and subjects with two or more new health problems in that period.

Our sample consisted of $49.2 \%$ males and $50.8 \%$ females, with a mean age of 54.7 years (standard deviation, SD 17 years). More than half of the population (51.5\%) had a low educational level (primary school, lower technical and vocational training), $35.7 \%$ had intermediate training, and $12.8 \%$ had a high level of education (university and higher vocational training). The majority (80.5\%) lived as a couple or in a family, 17.5\% lived alone, and 1.9\% had another type of living arrangement (e.g., home for the elderly).

\section{CONSULTATION RATE}

New data were collected to determine consultation rates using the patients' electronic medical records (EMR). Regular consultations, telephone consultations, and home visits were counted for each patient over a period of four years (1994-1997), using specially developed software. The validity of the computerised count of consultations was assessed in comparison with the finan- 
Table 1 Automated count of consultations in electronic medical records (EMR), versus bills in privately insured patients (45\%), from 1994 through 1997

\begin{tabular}{lrlll}
\hline Practice & & $\begin{array}{l}\text { EMR } \\
\text { mean } \\
\text { (4 years) }\end{array}$ & $\begin{array}{l}\text { Bills } \\
\text { mean } \\
\text { (4 years) }\end{array}$ & $\begin{array}{l}\text { Bills/EMR } \\
\times 100 \%\end{array}$ \\
\hline A & $N$ & 18.7 & 12.8 & $68 \%$ \\
B & 192 & 23.2 & 14.3 & $62 \%$ \\
C & 56 & 15.1 & 13.3 & $88 \%$ \\
D & 169 & 18.8 & 11.7 & $62 \%$ \\
E & 330 & 16.4 & 14.5 & $88 \%$ \\
F & 210 & 16.1 & 13.9 & $86 \%$ \\
G & 57 & 19.5 & 14.4 & $74 \%$ \\
H & 178 & 12.9 & 10.6 & $82 \%$ \\
I & 54 & 16.8 & 14.4 & $86 \%$ \\
Total & 75 & 17.8 & 13.2 & $74 \%$ \\
\hline
\end{tabular}

cial administration of privately insured patients, who pay per visit in the Netherlands ( $45 \%$ of the patients in the population under study).

\section{VALIDATION OF THE AUTOMATED CONSULTATION COUNT}

On average the number of contacts with the GP in the EMR per privately insured patient was 17.8 (SD 16.1) over the last 4 years, and the average number of bills per patient over the same period was 13.2 (SD 12.6). When analysed at practice level, two practices $(B$ and $D)$ had a relatively large discrepancy between the automated count of consultations and bills (see table 1 ). However, differences in numbers of consultations were a lot less pronounced when billing records of practices were compared with the computerised count of consultations. By checking the consultations of 30 randomly drawn patients per practice we found the following reasons for overestimation: GPs used the EMR to register different kinds of information other than consultations and home visits. For example, when they received important information from a family member of the patient, GPs sometimes made notes in the EMR without seeing the patient. Some GPs also used the EMR to register summaries of specialists' reports without using a specific code by which our program was able to identify the information as correspondence. Furthermore, results of lab assessments (in the practice or hospital lab), cervical smears, and X-rays were sometimes erroneously identified as consultations. Practices differed regarding the use of the EMR, the kind of information registered in the EMR, and (rarely) omissions in billing patients for consultations. Overall, the automated count seemed to yield an overestimation of consultation rates of about $25 \%$. In this study, the automated consultation 
count in the EMR was used to estimate the number of consultations per year for both publicly and privately insured patients.

\section{ANALYSIS}

The general outcome measure in this study is the number of consultations in 1997. Workload was calculated, for the sample of patients in the study, counting similar amounts of time for consultations, home visits, and telephone consultations. A comparison was made with three studies from other countries from which we were able to calculate a workload curve. ${ }^{1,8,26}$ In our study we used chi-square tests to analyse bivariate relations with sociodemographic variables, the number of chronic disease conditions and new health problems, consultation rates in previous years, and differences between practices. A least squares linear regression model was made, with a log-transformation of the number of consultations in 1997 as the dependent variable, and different sets of variables in the model. Variables of the basic model (sex, age, level of education, health insurance, and living arrangement) were included in all models. Subsequent models included the number of chronic disease conditions in 1994, the number of new health problems registered on the problem list in the previous four years (1994-1997; none, one, two or more per year), and consultation rates in the previous four years (1994-1997; $<5, \geq 5$ consultations per year). Differences between practices were assessed at different stages in the analyses. Practices were modelled as eight dummy variables against the first practice (A). All analyses were performed using BioMedical Data Package (BMDP), programmes 2D, 4F and $1 R .35$

\section{RESULTS}

The average number of consultations in 1997 was 5.5 (SD 5.7) and 5.3, $5.1,5.1$ in 1996,1995 , and 1994 respectively. In $199714.4 \%$ of the patients consulted not at all, $47.9 \% 1$ through 5 times, 32.3\% 6 through 15 times, and a minority of $5.5 \%$ consulted more than 15 times. The GP's workload was non-linearly related to the percentage of patients: one-fifth of the patients accounted for roughly $50 \%$ of the GP's time, and half consumed $80 \%$; similar figures were extracted from studies of other countries (figure 1). When tested bivariately, all sociodemographic characteristics were significantly related to the attendance rate in 1997. Frequent attendance was more common among females, among subjects with a lower educational level, among subjects on national health care insurance, and among the elderly. Subjects living alone and those with two or more chronic diseases also visited their GP more frequently. The consultation rate in 1997 was strongly related to the consultation rates in 


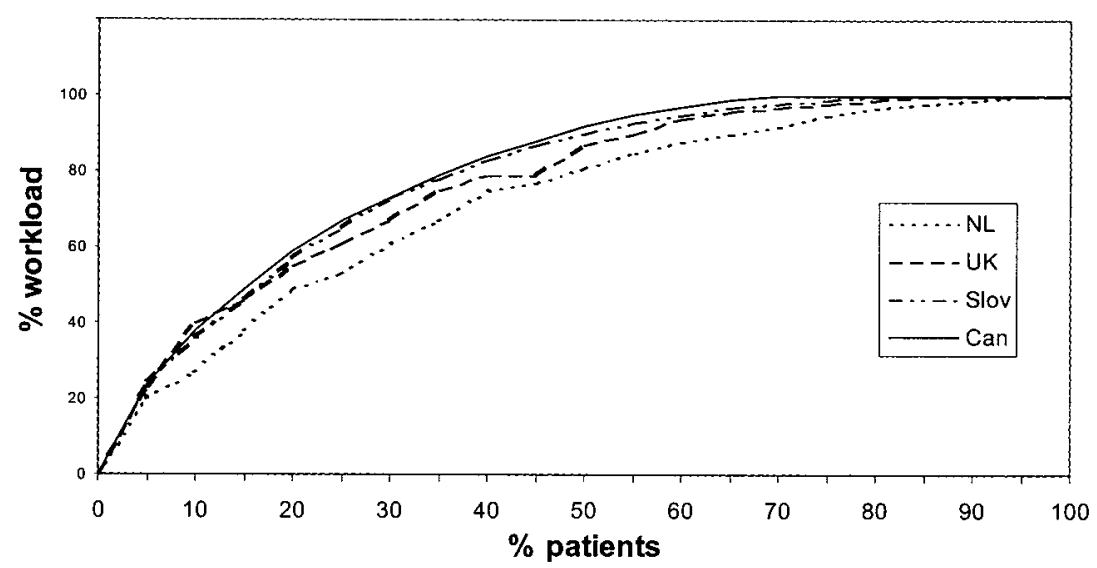

Figure 1 Workload related to patients.

previous years. Of the frequent attenders in the years 1996, 1995, and 1994, respectively $68 \%, 65 \%$, and $64 \%$ had a high consultation rate in 1997 as well. Newly registered health problems in the years 1994-1997 were strongly related to frequency of attendance in 1997 as well. Two practices had a significantly higher average consultation rate; however, when comparing urban to non-urban practices, and single working GPs to group practices, no differences were found in consultation rates.

Multivariate analysis (table 2) showed that sociodemographic variables (model 1) explained $9.0 \%$ of the variance in consultation rate in 1997. When chronic diseases were added a total of $16.6 \%$ of the variance was explained (model 2). As the next step, the number of new health problems during the last four years were added to the regression analysis (model 3 ), providing a total explained proportion of $20.2 \%$. Finally, the attendance rates in the previous three years were added (model 4 ), resulting in $31.6 \%$ of the variance being explained. Differences between practices revealed hardly any additional explanation of variance at different stages in the analysis (models $0,1^{\dagger}, 3^{\dagger}, 4^{\dagger}$ ). 
Table 2 Multiple linear regression analysis: level of significance of independent variables

\begin{tabular}{|c|c|c|c|c|c|c|c|c|}
\hline & $\begin{array}{l}\text { Model } \\
\text { of }^{\dagger}\end{array}$ & $\begin{array}{l}\text { Model } \\
1\end{array}$ & $\begin{array}{l}\text { Model } \\
1^{\dagger}\end{array}$ & $\begin{array}{l}\text { Model } \\
2\end{array}$ & $\begin{array}{l}\text { Model } \\
3\end{array}$ & $\begin{array}{l}\text { Model } \\
3^{t}\end{array}$ & $\begin{array}{l}\text { Model } \\
4\end{array}$ & $\begin{array}{l}\text { Model } \\
4^{\dagger}\end{array}$ \\
\hline \multicolumn{9}{|l|}{ Sociodemographic } \\
\hline Gender & & $\star \star$ & $\star$ & $\star \star$ & $\star \star$ & $\star \star$ & * & * \\
\hline Age (per 10 years) & & $\star \star$ & $\star \star$ & $\star \star$ & $\star \star$ & $\star \star$ & $\star$ & $* *$ \\
\hline Health insurance & & $\star \star$ & $\star \star$ & $\star$ & $\star$ & $\star$ & * & * \\
\hline Educational level & & ns & ns & ns & ns & ns & ns & ns \\
\hline \multicolumn{9}{|l|}{ Occupational status } \\
\hline low blue vs high blue & & ns & ns & ns & ns & ns & ns & ns \\
\hline vs low white & & ns & ns & ns & ns & ns & ns & ns \\
\hline vs high white & & ns & ns & ns & ns & ns & ns & ns \\
\hline vs other & & ns & ns & ns & ns & ns & ns & ns \\
\hline $\begin{array}{l}\text { Living arrangement } \\
\text { (alone versus other) }\end{array}$ & & ns & ns & ns & ns & ns & ns & ns \\
\hline \multicolumn{9}{|l|}{ Health status } \\
\hline$N$ of chronic diseases ${ }^{b}$ & & & & $\star \star$ & $\star \star$ & $\star \star$ & * * & $* *$ \\
\hline $\mathrm{N}$ of new diseases in 1997 & & & & & $\star \star$ & $\star \star$ & $\star \star$ & $\star \star$ \\
\hline $\mathrm{N}$ of new diseases in 1996 & & & & & $\star \star$ & $\star \star$ & * & $\star \star$ \\
\hline $\mathrm{N}$ of new diseases in 1995 & & & & & ns & ns & ns & ns \\
\hline$N$ of new diseases in 1994 & & & & & $\star \star$ & $\star \star \star$ & ns & ns \\
\hline \multicolumn{9}{|l|}{ Consultations } \\
\hline Consultation rate in 1996 & & & & & & & ** & $\star \star$ \\
\hline Consultation rate in 1995 & & & & & & & $* *$ & ** \\
\hline Consultation rate in 1994 & & & & & & & ** & ** \\
\hline Explained variance & $1.4 \%$ & $9.0 \%$ & $10.2 \%$ & $16.6 \%$ & $20.2 \%$ & $21.3 \%$ & $31.6 \%$ & $32.5 \%$ \\
\hline
\end{tabular}

$\dagger$ Adjusted for general practice

$\star * p<0.05$

$\star *=p<0.01$

ns Stands for no statistical significance

a. Registered ICPC codes, level 70-99, in the registration network (see methods)

b. 35 Prevalent chronic disease conditions, such as diabetes mellitus, cardio-vascular diseases, etc.

\section{DISCUSSION}

The distribution of workload per percentage of patients in our sample is very similar to that reported in other countries ${ }^{1,8,26}$, a phenomenon mentioned earlier by Neal et al. ${ }^{1}$ The consistency of this finding is remarkable, since the health care systems of these countries are different with regard to financial reward of GPs, whether GPs operate personal lists, whether GPs are gate keepers for 
hospital care, and the amount of preventive work done by GPs. Sex, age, and type of insurance explain $9 \%$ of the variance of attendance rates, chronic and new health problems another $11 \%$, and visiting patterns in previous years an additional $11 \%$.

The main methodological limitation of this study is the sampling procedure, in which subjects with one or more new health problems in the previous three years are over-represented. ${ }^{34} \mathrm{We}$ found a relatively high average attendance rate of 5.5 consultations in 1997 . Even when the rates are corrected for the $25 \%$ overestimation, they are still high when compared with other studies in the Netherlands, reporting average consultation rates between 2.8 and 3.0 in 1997. ${ }^{36,37}$ Another limitation of our study is the overestimation of consultations generated by the computer count. Since the financial administration showed similar number of bills between practices, this seems to be due to differences in registration habits between GPs. The GP's experience with the EMR programme, user friendliness of the programme, and fluidity of typing will influence the GP's accuracy. Illustrative of this is another study comparing simultaneously registered hand-written and computer consultation notes, which found systematically higher attendance rates in computer notes. ${ }^{23}$ Although checking chart notes by hand may be more precise, interpretation bias can only be prevented when the results of at least two independent raters are compared. In studies on large numbers of patients over longer periods of time, checking notes by hand does not seem a realistic option. In addition, patients generally have more contacts with their GP than the number of contacts registered. Telephone consultations and contacts while accompanying a family member are quite often not registered.

A striking finding is that differences between practices did not influence attendance rates in our study. Even when 'practice' was entered as a variable in the multivariate model first, it hardly explained any variance in consultation rates. Since the number of bills sent out to privately insured patients was quite similar in all practices, differences between practices in consultation rates seemed largely due to differences in registration habits. Another explanation may be that all nine practices participated in a research network and were therefore not fully representative of practice variability in the Netherlands. In studies from the UK and the US differences between practices and provider-related variables were reported to play a more important role. ${ }^{1,4}$ However, also in the UK study, differences in registration habits between practices may have resulted in the small and systematic difference in the number of frequent attenders. ${ }^{1}$

Disease, reassuringly, still is a main contributor to patients' attendance; on the other hand, visiting patterns of patients (independent from disease) are responsible for a similar amount of consultations. High attendance without identifiable organic disease is not necessarily a reason for concern. Patients with a 
somatisation tendency or patients under chronic stressful circumstances, for example, may visit their GP more often with unexplained symptoms. When these are adequately dealt with, GPs may be able to prevent unnecessary or even harmful investigations, referrals, and treatments. Of importance is how patients and doctors value the usefulness of contacts. ${ }^{38}$ Elevated attendance rates are reasons for concern only when doctors or patients are getting frustrated, or when the quality of care is insufficient; often these two go hand in hand. ${ }^{24,28}$ The extreme of very frequent attendance easily leads to communication problems, which may be hard to influence. ${ }^{39}$ Further research on the role of patient-related psychosocial factors, reasons for encounter, patients' agendas for consultations, and the communication process in consultations is recommended. $38,40,41$

We conclude that one-third of the variance in attendance is explained by disease and consultation patterns in previous years, and that differences between practices were only of marginal importance. We recommend further research on the role of patient-related psychosocial factors on attendance rate, and qualitative research on the contents of consultations and patterns of communication between patients and their GPs. 


\section{REFERENCES}

1. Neal RD, Heywood PL, Morley S, Clayden AD, Dowell AC. Frequency of patients' consulting in general practice and workload generated by frequent attenders: comparisons between practices. BrJ Gen Pract 1998;48:895-898.

2. Heywood PL, Blackie GC, Cameron IH, Dowell AC. An assessment of the attributes of frequent attenders to general practice. Fam Pract 1998;15:198-204.

3. Grol R, Grimshaw J. Evidence-based implementation of evidence-based medicine. $J t$ Comm J Qual Improv 1999;25:503-513.

4. Phillips KA, Morrison KR, Andersen R, Aday LA. Understanding the context of healthcare utilization: assessing environmental and provider-related variables in the behavioral model of utilization. Health Serv Res 1998;33:571-596.

5. Carr-Hill RA, Rice N, Roland M. Socioeconomic determinants of rates of consultation in general practice based on fourth national morbidity survey of general practices. BMJ 1996;312:1008-1013.

6. Corney RH. Sex differences in general practice attendance and help seeking for minor illness. J Psychosom Res 1990;34:525-534.

7. Karlsson H, Lehtinen V, Joukamaa M. Frequent attenders of Finnish public primary health care: sociodemographic characteristics and physical morbidity. Fam Pract 1994;1:424-430.

8. Browne G, Humphrey R, Pallister R, Browne J, Shetzer L. Prevalence and characteristics of frequent attenders in a prepaid Canadian practice.J Fam Pract 1982;14:63-71.

9. Yuen P, Balarajan R. Unemployment and patterns of consultation with their general practitioner. BMJ 1989;298:1212-1214.

10. Katon W, Von Korff M, Lin E, et al. Distressed high utilizers of medical care. DSM-III-R diagnoses and treatment needs. Gen Hosp Psychiatry 1990;12:355-362.

11. Karlsson $H$, Lehtinen V, Joukamaa $M$. Are frequent attenders of primary health care distressed? Scand J Prim Health Care 1995;13:32-38.

12. Andersson SO, Mattsson B, Lynoe N. Patients frequently consulting general practitioners at a primary health care centre in Sweden-a comparative study. Scand J Soc Med 1995;23:251-257.

13. Portegijs PJM, Jeuken FM, van der Horst FG, Kraan HF, Knottnerus JA. A troubled youth: relations with somatization, depression and anxiety in adulthood. Fam Pract 1996;13:1-11.

14. Ellaway A, Wood S, Macintyre S. Someone to talk to? The role of loneliness as a factor in the frequency of GP consultations. Br J Gen Pract 1999;49:363-367.

15. Robinson JO, Granfield AJ. The frequent consulter in primary medical care. $J$ Psychosom Res 1986;30:589-600.

16. Westhead JN. Frequent attenders in general practice: medical, psychological and social characteristics. J R Coll Gen Pract 1985;35:337-340.

17. Tessler R, Mechanic D, Dimond M. The effect of psychological distress on physician utilization: a prospective study. J Health Soc Behav 1976;17:353-364. 
18. Murray J, Corney R. Locus of control in health: the effects of psychological well-being and contact with the doctor. Int J Soc Psychiatry 1989;35:361-369.

19. Mechanic D. Health and illness behaviour and patient-practitioner relationships. Soc Sci Med 1992;34:1345-1350.

20. Lipowski ZJ. Somatization: The concept and its clinical application. Am J Psychiatry 1988;145:1358-1368.

21. Mumford DB, Devereux TA, Maddy PJ, JohnstonJV. Factors leading to the reporting of 'functional' somatic symptoms by general practice attenders. $\mathrm{Br} J$ Gen Pract 1991;41:454-458.

22. Bridges K, Goldberg D, Evans B, Sharpe T. Determinants of somatization in primary care. Psychol Med 1991;21:473-483.

23. Neal R, Heywood P, Morley S. Real world data-retrieval and validation of consultation data from four general practices. Fam Pract 1996;13:455-461.

24. Mathers N, Jones N, Hannay D. Heartsink patients: a study of their general practitioners. Br J Gen Pract 1995;45:293-296.

25. Olesen $F$. The pattern of attendance at general practice in the years before the diagnosis of cervical cancer. A case control study. Scand J Prim Health Care 1988;6:199-203.

26. Svab I, Zaletel Kragelj L. Frequent attenders in general practice: a study from Slovenia. Scand J Prim Health Care 1993;11:38-43.

27. Martin E, Russell D, Goodwin S, Chapman R, North M, Sheridan P. Why patients consult and what happens when they do. BMJ 1991;303:289-292.

28. Mayou R, Sharpe M. Patients whom doctors find difficult to help. An important and neglected problem. Psychosomatics 1995;36:323-325.

29. Scaife B, Gill P, Heywood P, Neal R. Socio-economic characteristics of adult frequent attenders in general practice: secondary analysis of data. Fam Pract 2000;17: 298-304.

30. Metsemakers JFM, Höppener P, Knottnerus JA, Kocken RJJ, Limonard CBG. Computerized health information in the Netherlands: a registration network of family practices. BrJ Gen Pract 1992;42:102-106.

31. Lamberts $\mathrm{H}$, Wood M. International Classification of Primary Care. Oxford: Oxford University Press, 1987.

32. WONCA CCo. ICHPPC-2 defined International Classification of Health Problems in Primary Care. Oxford: Oxford University Press, 1983.

33. Metsemakers J. Unlocking patients' records in general practice for research, medical education and quality assurance: Registration Network Family Practices. Ph.D. thesis: University of Maastricht, 1994.

34. van den Akker M, Buntinx F, Metsemakers J, Knottnerus J. Marginal impact of psycho-social factors on multimorbidity: results of an explorative nested case-control study. Soc Sci Med 2000;50:1679-1693.

35. Dixon W, Brown M, Engelman L, RI J. BMDP. Statistical Software Manual. Berkeley, CA: University of California Press, 1990. 
36. de Bakker D, Kulu-Glasgow I, Abrahamse H, et al. Annual report LINH 1997 (in Dutch). Utrecht: NIVEL, 1998.

37. van de Werf GTh, Smith RJA, Stewart RE, Meyboom-de Jong B. Spiegel op de huisarts, over registratie van ziekte, medicatie en verwijzingen in de geautomatiseerde huisartspraktijk Registratie Netwerk Groningen. Groningen: Huisartsgeneeskunde Universiteit Groningen, 1998.

38. Salmon P, Peters S, Stanley I. Patients' perception of medical explanations for somatisation disorders: qualitative analysis. BMJ 1999;318:372-376.

39. Jiwa $M$. Frequent attenders in general practice: an attempt to reduce attendance. Fam Pract 2000;17:248-251.

40. van de Kar A, Knottnerus JA, Meertens R, Dubois V, Kok G. Why do patients consult the general practitioner? Determinants of their decision. Br J Gen Pract 1992;42:313-316.

41. Barry CA, Bradley CP, Britten N, Stevenson A, Barber N. Patients' unvoiced agendas in general practice consultations: a qualitative study. BMJ 2000;320:1246-1250. 


\section{Chapter 3}

Somatisation in primary care: clinical judgement and standardised measurement compared 


\begin{abstract}
Background In daily practice, general practitioners (GPs) generally rely on their clinical judgement in assessing whether patients somatise distress. Nevertheless, conclusions derived from research on somatisation in primary care are largely based on standardised measurements of somatisation. We investigated the relation between the GPs' clinical judgement of somatisation and a somatisation research instrument (DSM-III-R), and examined how both operationalisations of somatisation related to other important variables.
\end{abstract}

Methods In 14 general practices, 407 frequently attending patients answered a questionnaire on somatisation symptoms, while the GPs gave their judgement on somatisation, and communication for each patient. Other variables were extracted from the registered health status of the patients.

Results We found a weak association (correlation: 0.27) between the GPs' judgement and the research instrument; however, relations with other variables showed that both operationalisations were very similar constructs. The research instrument incorporated more psychological problems (depression and anxiety), while the GPs' judgement of somatisation was influenced by the attendance rate and by aspects of communication with the patient.

Conclusion For research addressing somatisation in primary care as a practical clinical problem, the operationalisation of somatisation should include the clinical judgement of the practitioner, thereby widening the focus from co-morbid mental disturbances to communication aspects. 


\section{INTRODUCTION}

In primary care, mainly mild forms of somatisation need to be addressed. Patients with psychological disturbances may present with distress-related physical symptoms. When not diagnosed adequately, such requests for help easily end in misuse of medical resources, and in communication problems between patient and general practitioner (GP) ${ }^{1-3}$ Definitions of somatisation have been proposed for research in primary care, such as abridged DSM-III-R somatisation (Diagnostic Statistical Manual of Psychiatric Disorders $3^{\text {rd }}$ revised edition ${ }^{4}$ ), making use of a standardised list of 37 symptoms. ${ }^{1,2,5-7}$ Abridged somatisation has a prevalence in the open population of about $5 \%$, and from $10 \%$ to $35 \%$ in GP surgeries. ${ }^{5-8}$ GPs in daily practice, however, do not generally assess somatisation with a time-consuming standardised interview or questionnaire. They mostly rely on their clinical experience formed in the (numerous) previous contacts with the patient, in assessing whether patients somatise distress. In order to interpret the results of scientific research in daily practice, it is important to evaluate to what extent clinical judgement of somatisation overlaps with standardised interviews on somatisation. We have observed that both definitions of somatisation do not always overlap, and that clinical judgement seems to be related more to actual behaviour of patients (for example: number of and reasons for consultations). An evaluation is needed of the construct validity of both standardised measurement and clinical judgement, with other variables expected to be associated with somatisation. In our hypothesis, such variables are attendance rate, psychosocial problems, somatisation symptoms in the patient's chart, communication problems between patient and GP, and sociodemographic characteristics. ${ }^{1-5,7}$ In this context, the following question is addressed in the present study: what is the relation between the GPs' clinical judgement of somatisation and a standardised patient questionnaire on somatisation (abridged DSM-III-R), and what is the construct validity of both operationalisations of somatisation in relation to other important variables?

\section{SUBJECTS AND METHODS}

\section{SETTING}

The study was performed in 15 general practices (with 26 GPs), all participating in the Family Practice Registration Network (RegistratieNet Huisartspraktijken, $\mathrm{RNH}$ ) in the south of the Netherlands, providing data on the patients' health status. ${ }^{9}$ The patient records contain sociodemographic characteristics, and all relevant health problems in the 'health problem list', and are used and revised daily by the GPs in the network. The health problem list contains 
permanent, chronic (more than six months), or recurrent problems, also including risk factors, and psychosocial problems. Health problems are coded according to the diagnostic criteria of ICPC (International Classification of Primary Care ${ }^{10}$ ). The quality of the data in the problem lists is ensured by instruction and training sessions, regional consensus groups, quality control experiments, and an automated thesaurus and automated checking for erroneous or missing entries. Reliability and completeness have been shown by comparisons between the Registration Network's cancer data and the data of the regional cancer registry, and between the Registration Network's epilepsy data and the Maastricht epilepsy case register. ${ }^{11}$

\section{SUBJECTS}

The selected subjects were frequent attenders with 15 or more consultations with their GP over the previous three years on initiative of the patient. Consultations were counted with a computer programme. Routine examinations on the initiative of the GP, such as cervical smears or blood pressure measurements, were not included in the consultation count. GPs differed in their registration habits of consultations and the computerised count of consultations was not $100 \%$ reliable. Because of the large number of patients followed over three years time, we were not able to double-check by hand the data on consultations, and decided to use the computer count of consultations in this study. To diminish the influence of serious disease as a cause of symptoms, we selected younger patients between 20 and 45 years of age, without serious somatic or mental diseases. Patients with the following diseases on their health problem list were excluded: cancer, AIDS, rheumatoid arthritis, multiple sclerosis, dementia, schizophrenia, mental retardation, and psychosis. We did not adjust our data for other groups of patients who might be expected to attend frequently, such as women of childbearing age with questions about pregnancy. In our population (20- to 45-year-olds, general practice in the Netherlands), we aimed to select the

Table $1 \mathrm{GPs}^{\prime}$ judgement of somatisation ( 1 is no somatisation, 5 severe somatisation) versus count of DSM-III-R somatisation symptoms

\begin{tabular}{|c|c|c|c|c|c|c|c|}
\hline \multicolumn{7}{|c|}{ GP } & \multirow[t]{2}{*}{ Total } \\
\hline & & 1 & 2 & 3 & 4 & 5 & \\
\hline \multirow[t]{4}{*}{ DSM } & $0-4$ & 22 & 26 & 21 & 49 & 15 & 133 \\
\hline & $5-12$ & 25 & 34 & 40 & 86 & 65 & 250 \\
\hline & $13+$ & 1 & 1 & 4 & 8 & 10 & 24 \\
\hline & Total & 48 & 61 & 65 & 143 & 90 & 407 \\
\hline
\end{tabular}




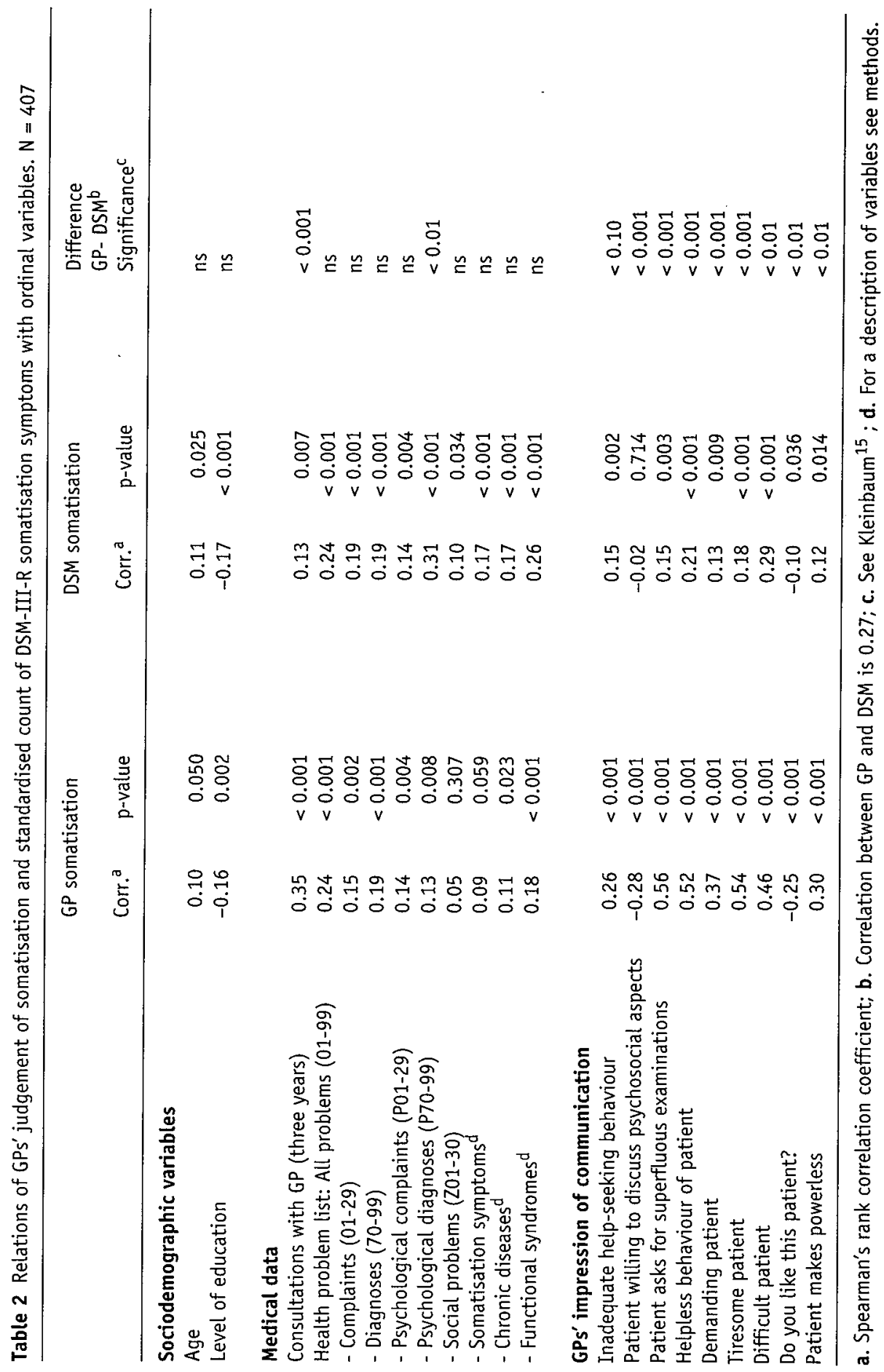


$10 \%$ most frequently visiting patients. ${ }^{12}$ To limit the workload for the GPs, a maximum of 50 patients per practice were included in the study.

\section{INSTRUMENTS}

The selected subjects received a questionnaire plus reminder by mail, inquiring after somatisation symptoms during their life. The questionnaire was developed by the authors (and validated in a pilot study), and contained the 37 somatisation symptoms listed in DSM-III-R, as well as the format of in- and exclusion of symptoms used in DSM-III-R. ${ }^{4}$ In DSM-III-R, symptoms count if they are rated by the patient as important (patient saw a physician, took medicine, or altered lifestyle), and if they are not explained adequately by somatic disorder or physical injury, and if they are not the side effects of medicine, drugs, or alcohol. ${ }^{4}$ In our study, symptoms did not count when explained by organic disease, based on the examination of the GP or specialist, as reported by the patients in our questionnaire. The GPs filled in a short questionnaire (developed by the authors) for every patient about the degree of somatisation (five-point Likert scale; 1 is no somatisation and 5 severe somatisation). The GP questionnaire also contained questions on communication problems with the patient, used and validated in an earlier study ${ }^{13}$ (these questions are listed in table 2 under 'impression of GP communication'). Other variables extracted from the network were: sociodemographic characteristics, the number of consultations with the GP in the previous three years, and the health problem lists. In the health problem lists, the psychological and social chapters were analysed in two different ways: as separate ICPC codes, and as count of psychological symptoms, psychological diagnoses and social problems. Other ICPC chapters were analysed in clusters relevant to somatisation: a count of chronic disease conditions (81 diseases such as osteoarthritis, asthma, diabetes ${ }^{14}$ ), a count of somatisation symptoms (58 ICPC codes referring to DSM-III-R somatisation ${ }^{4,7}$ ), and a count of five functional syndromes explicitly coded in ICPC (irritable bowel syndrome, fibromyalgia, migraine, hyperventilation, and pre-menstrual syndrome).

\section{ANALYSIS}

Non-parametric tests are used throughout: Spearman rank correlation and Mann-Whitney $U$ tests. The two operationalisations of somatisation are compared with each other using a linear regression analysis. To compare associations of variables with both the GPs' judgement and the questionnaire, we used a single sample test for the equality of two correlations (table 2), as described by Kleinbaum, ${ }^{15}$ and a Mann-Whitney U test (table 3 ) on the Z-score (of the GPs' judgement) minus the $Z$-score (of the questionnaire). Predictors of DSM-III-R somatisation and clinical judgement were analysed with logistic regression (backward elimination, median split). 
Table 3 Relations of GPs' judgement of somatisation and standardised count of DSM-III-R somatisation symptoms with nominal variables. $\mathrm{N}=407$

\begin{tabular}{|c|c|c|c|c|c|c|c|}
\hline & & & $G P$ & & DSM & & \\
\hline & & $N$ & mean $^{a}$ & sign. ${ }^{b}$ & median & sign. ${ }^{b}$ & diff. $^{c}$ \\
\hline \multicolumn{8}{|l|}{ Sociodemographic } \\
\hline \multirow[t]{2}{*}{ Gender } & female: & 335 & 3.5 & ns & 6 & $p=0.02$ & ns \\
\hline & male: & 72 & 3.2 & & 5 & & \\
\hline \multirow[t]{2}{*}{ Marital status } & unmarr: & 104 & 3.5 & ns & 6 & ns & ns \\
\hline & married: & 303 & 3.4 & & 6 & & \\
\hline \multirow[t]{2}{*}{ Living situation } & single: & 74 & 3.7 & $\mathrm{p}=0.007$ & 6 & ns & ns \\
\hline & family: & 332 & 3.3 & & 6 & & \\
\hline \multirow[t]{2}{*}{ Health insurance } & public: & 347 & 3.4 & ns & 6 & ns & ns \\
\hline & private: & 61 & 3.4 & & 6 & & \\
\hline \multicolumn{8}{|l|}{ Psychosocial problems $^{d}$} \\
\hline \multirow[t]{2}{*}{ Depressive disorder (P76) } & present: & 25 & 3.8 & $\mathrm{p}=0.08$ & 9 & $p=0.002$ & ns \\
\hline & absent: & 382 & 3.4 & & 6 & & \\
\hline \multirow[t]{2}{*}{ Depressive complaints (P03) } & present: & 17 & 4.0 & $p=0.04$ & 8 & $p=0.04$ & ns \\
\hline & absent: & 390 & 3.4 & & 6 & & \\
\hline \multirow[t]{2}{*}{ Suicide attempt (P77) } & present: & 5 & 4.2 & ns & 8 & ns & ns \\
\hline & absent: & 402 & 3.4 & & 6 & & \\
\hline \multirow[t]{2}{*}{ Depressive symptoms ${ }^{\mathrm{e}}$} & present: & 48 & 3.8 & $p=0.01$ & 8 & $p<0.001$ & $p=0.09$ \\
\hline & absent: & 359 & 3.4 & & 6 & & \\
\hline \multirow[t]{2}{*}{ Anxiety disorder (P74) } & present: & 18 & 3.5 & ns & 7 & $p=0.007$ & $p=0.04$ \\
\hline & absent: & 389 & 3.4 & & 6 & & \\
\hline \multirow[t]{2}{*}{ Anxiety complaints (P01) } & present: & 27 & 3.7 & ns & 8 & $p=0.01$ & ns \\
\hline & absent: & 380 & 3.4 & & 6 & & \\
\hline \multirow[t]{2}{*}{ Personality disorder (P80) } & present: & 14 & 3.9 & $\mathrm{p}=0.10$ & 9 & $p=0.002$ & ns \\
\hline & absent: & 393 & 3.4 & & 6 & & \\
\hline \multirow[t]{2}{*}{ Separation/death spouse (Z15) } & present: & 9 & 3.8 & ns & 11 & $p=0.03$ & $p=0.06$ \\
\hline & absent: & 398 & 3.4 & & 6 & & \\
\hline
\end{tabular}

a. The mean was given instead of the median, because the median was 4 for all variables

b. Mann-Whitney U

c. Mann-Whitney $\mathrm{U}$ on the Z-score of the $\mathrm{Gps}^{\prime}$ judgement minus the Z-score of the questionnaire

d. Only psychosocial problems with significant results are listed

e. One or more of the following ICPC coded symptoms: depressive feelings, sleep problems, tiredness, fear of death, loosing/gaining weight, and difficult concentration 


\section{RESULTS}

\section{DESCRIPTION OF PATIENTS}

The 15 practices had 16,367 patients between 20 and 45 years of age, of which 1,476 visited their GP frequently, without serious disease. The somatisation questionnaire was returned by 986 frequent attenders (response rate $67 \%$ ). Non-respondents were relatively often unmarried men, living alone, relatively often with psychological problems, especially addiction to alcohol and hard drugs. No information was available why patients did not respond; one reason may have been that the questionnaire was rather long and complicated to answer. One GP dropped out, and in the other 14 practices we asked GPs to answer the somatisation questionnaire on a maximum of 50 randomly chosen patients (depending on the size of the practice). Complete data were obtained on 407 patients, $334(82 \%)$ of which were female, with a median age of 36 years. Most patients had a low (57\%), or intermediate (39\%) level of education, $82 \%$ shared a household, and $85 \%$ had public health insurance. According to their GP, $51 \%$ of the patients were strong or very strong somatisers. Of the selected patients, $33 \%$ had between 0 and 4 somatisation symptoms in their life, $61 \%$ had between 5 and 12 symptoms, and only $6 \%$ had 13 or more symptoms (table 1 ).

\section{GENERAL PRACTITIONERS' JUDGEMENT VERSUS QUESTIONNAIRES}

The clinical judgement and the questionnaire had a correlation coefficient of 0.27 (linear regression coefficient of 0.77 ). Only $7 \%$ of the variance of the patient questionnaire on somatisation was explained by the GPs' judgement of somatisation. When the results of the questionnaire were dichotomised at the cut-off point of five symptoms, the odds ratio was 1.35 (CI: 1.15-1.58) per unit of the GP Likert scale. Higher or lower cut-off values of the questionnaire did not yield better odds ratios.

\section{GENERAL PRACTITIONERS' JUDGEMENT}

Based on the GPs' responses, older patients, patients with low education, and patients living alone presented more often somatisation symptoms than younger, higher educated patients, living in a family (table 2 and 3). The frequency of attendance was strongly related to the GPs' judgement of somatisation. Psychological diagnoses were associated with GP somatisation; a relation with social problems was not found. Analysis of specific psychological and social ICPC codes yielded a relation with depressive disorder, while no relations were found with anxiety or personality disorders. We found a strong relation with all items on the GPs' impression of communication problems. Closest to the GPs' judgement of somatisation were: 'patient is asking for superfluous medical examinations', 'helpless behaviour of patient', 'tiresome patient', and 'difficult patient'. 
Independent predictors of GP somatisation were (in order of importance): 'patient is asking for superfluous medical examinations', patients living alone, 'tiresome patient', 'helpless behaviour of patient', chronic diseases in the problem list, social problems in the problem list, and the length of the problem list.

\section{THE STANDARDISED PATIENT QUESTIONNAIRE ON SOMATISATION}

Somatisation as measured by the questionnaire was associated with older age, lower level of education, and female gender. It was weakly associated with the number of consultations, and moderately associated with the number of health problems; both symptoms and diagnoses contributed to the relation. Chronic diseases and somatisation symptoms related moderately to the questionnaire, and functional syndromes did so strongly. Psychological diagnoses related strongly to the questionnaire, social problems only weakly. Depressive disorder, anxiety disorders, personality disorders, and separation or death of spouse were all related to the questionnaire. The questionnaire correlated strongly with the label 'difficult patient', 'helpless behaviour of patient', and 'tiresome patient'. Independent predictors of DSM somatisation were (in order of importance): functional syndromes in problem list, 'difficult patient', the number of psychological diagnoses, 'inadequate help-seeking behaviour', and depressive symptoms in the problem list.

\section{COMPARISON OF RELATIONS}

The right-hand columns of table 2 and 3 show that most relations of the clinical judgement with the other data were not significantly different from the relations of the patient questionnaire with the other data. No differences were found in relation to sociodemographic variables, the total number of health problems, social problems, or selections of chronic problems, and functional syndromes. The GPs' judgement of somatisation was related more strongly to attendance rate and aspects of communication, whereas the questionnaire related stronger to anxiety disorders, and probably also to depressive disorder and separation or death of spouse.

\section{DISCUSSION}

For two variables aiming to measure the same concept, the GPs' judgement and the standardised measurement of somatisation were only weakly related. However, relations with other variables showed that both operationalisations of somatisation are very similar constructs. In other words, the clinical judgement and the standardised measurement of somatisation identified different 
individuals, but with very similar features, which indicates there is some validity in the diagnosis made either way. Even though we asked the GPs to use their own judgement, instead of using a standardised criterion list, ${ }^{8}$ the weakness of the correlation is surprising. The standardised measurement of somatisation included more patients with psychosocial disturbances, whereas the GPs' judgement was influenced strongly by attendance rate and communication aspects with the patient. The question arises, whether this weak link has implications for clinical management. Results of studies on somatisation based on standardised counts of symptoms may be hard to interpret in daily practice. A number of studies have included elements of clinical opinion in their definition of somatisation in general practice. ${ }^{16,17}$

Chronic somatic disease and somatisation are not mutually exclusive. Chronic disease may increase the risk of somatisation; reciprocally, somatisation with more frequent examinations may increase the chance for chronic diseases to be discovered.

\section{METHODOLOGICAL CONSIDERATIONS}

By selecting frequent attenders for our study, the relation between attendance rate and somatisation will have been weakened. In the unselected population of consultation hours, this relation must be even stronger. As a result of the selection procedure, the prevalence of somatisation, mental disorders and communication problems will have been enhanced. For the purpose of this study, high attendance seems an appropriate selection criterion, as it ensured the presence of a high percentage of patients in the study, with a tendency to somatise distress. $1,3,7,18,19$ Non-respondents were more often men, living alone, with addiction problems. Another study reported a similar non-respondents selection. ${ }^{20}$

\section{MENTAL DISORDERS AND SOMATISATION}

A striking finding is that somatisation according to the questionnaire was relatively often associated with mental problems, while somatisation according to the GP only showed a weak relationship with mental problems. Similar results were reported by Peveler and co-workers, who asked GPs to estimate somatisation according to the criteria of abridged somatisation. ${ }^{8}$ Peveler found that mood disorders were present in $61 \%$ of the somatisers according to DSM-III-R, and only in $25 \%$ of patients who somatised according to their GP. It has been suggested that GPs do not detect depression and anxiety disorders well when patients present distress-related somatic complaints. ${ }^{16,21,22}$ However, this does not seem a satisfactory explanation in our study, since we adopted psychosocial problems from the GPs' patient charts (and they, therefore, must have been known to the GPs). More likely, our GPs were aiming for a high speci- 
ficity, and accepted a lower sensitivity, in judging somatisation. ${ }^{23}$ Although some patients initially presented with somatic complaints, GPs avoided labelling these patients as somatisers when more acceptable, empowering, and temporary psychosocial explanations of symptoms were at hand (such as bereavement, difficulties at work, and depression). ${ }^{24}$ This mechanism has been described earlier as a style typical for GPs. ${ }^{8,25}$ One of the major tasks of GPs is to select patients with treatable conditions, and to prevent unnecessary treatment, referral, or medical labelling. ${ }^{25,26}$ Effectiveness of treatment of somatisation has hardly been studied, ${ }^{27}$ although management strategies of somatisation for GPs have been described. ${ }^{17,28,29}$ Connecting with the patient's beliefs, and offering tangible non-blaming symptom explanations are perceived as most helpful by patients with a tendency to somatise distress, but only a minority of GPs succeeded in doing so, according to patients. ${ }^{24}$ As is also reflected in the problems with communication reported by the GPs in our study, this suggests the need for training of GPs in attitude and communication skills, with a focus on the presentation of unexplained symptoms.

\section{GENERAL PRACTITIONERS' IMPRESSION OF COMMUNICATION}

According to the GPs, patients with a tendency to somatise distress were difficult, tiresome patients, asking for superfluous medical examinations, and clearly not willing to discuss psychosocial aspects. Mayou and Sharpe ${ }^{3}$ summarised the results of four studies on difficult patients, both in general practice and in secondary care clinics. According to the doctors in these studies, difficult patients were distressed frequent attenders, more likely to have abnormal personalities, and there was more often a discrepancy in expectations of care between doctor and patient. They stressed the importance of the quality of communication between doctor and patient. ${ }^{3}$ Differences in expectations of care between doctor and patient will lead to persistent symptom presentation, and to the experience of difficulty and frustration at both sides. The labels 'difficult', 'tiresome', or even 'frustrating', 'heartsink', or 'hateful' patient indicate frustrated and insufficient communication patterns between doctor and patient that need to be addressed. ${ }^{3,30,31}$ Illustrative is a study reporting that $60 \%$ of the variance in the number of 'heartsink' patients was explained by the variables perceived workload, job satisfaction, training in counselling, and postgraduate training. ${ }^{32}$

\section{CONCLUSION}

We conclude that somatisation according to clinical judgement and standardised measurement are weakly related to each other, and that both definitions of somatisation show acceptable construct validity. The GPs' judgement of 
somatisation seems valuable in daily practice, with a high specificity in excluding known psychological problems, and strongly influenced by the attendance rate of the patient, and by the GPs' impression of communication problems. The standardised measurement of somatisation is valid as a research instrument, selecting patients with high numbers of unexplained physical symptoms, including symptoms related to depression, anxiety, and personality disorders. For research addressing somatisation as a practical clinical problem, the operationalisation of somatisation should include the clinical judgement of the practitioner as well, thereby widening the focus from co-morbid mental disturbances to communication aspects. Further predictive validation of clinical judgement and standardised measurement of somatisation is possible through longitudinal follow-up of somatising patients in primary care. 


\section{REFERENCES}

1. Katon WJ, Lin E, Von Korff M, Russo J, Lipscomb P, Bush T. Somatization: a spectrum of severity. Am J Psychiatry 1991;148:34-40.

2. Escobar JI, Rubio-Stipec M, Canino G, Karno M. Somatic symptom index (SSI): a new and abridged somatization construct. Prevalence and epidemiological correlates in two large community samples. J Nerv Ment Dis 1989;177:140-146.

3. Mayou R, Sharpe M. Patients whom doctors find difficult to help. An important and neglected problem. Psychosomatics 1995;36:323-325.

4. American Psychiatric Association. Diagnostic and statistical manual of mental disorders, $3^{\text {rd }}$ ed. revised. Washington DC: American Psychiatric Association, 1987: 261-264.

5. Gureje O, Simon GE, Ustun TB, Goldberg DP. Somatization in cross-cultural perspective: a World Health Organization study in primary care. Am J Psychiatry 1997;154:989-995.

6. Kirmayer LJ, Robbins JM. Three forms of somatization in primary care: prevalence, co-occurrence, and sociodemographic characteristics. J Nerv Ment Dis 1991;179: 647-655.

7. Portegijs PJM, van der Horst FG, Proot IM, Kraan HF, Gunther NC, Knottnerus JA. Somatization in frequent attenders of general practice. Soc Psychiatry Psychiatr Epidemiol 1996;31:29-37.

8. Peveler R, Kilkenny L, Kinmonth AL. Medically unexplained physical symptoms in primary care: a comparison of self-report screening questionnaires and clinical opinion. J Psychosom Res 1997;42:245-252.

9. Metsemakers JFM, Knottnerus JA, van Schendel GJ, Kocken RJJ, Limonard CBG. Unlocking patients' records in general practice for research, medical education and quality assurance: the Registration Network Family Practices. Int J Biomed Comput 1996;42:43-50.

10. Lamberts $\mathrm{H}$, Wood M. International Classification of Primary Care. Oxford: Oxford University Press, 1987.

11. Metsemakers J. Unlocking patients' records in general practice for research, medical education and quality assurance: Registration Network Family Practices. Ph.D. thesis: University of Maastricht, 1994.

12. de Bakker D, Kulu-Glasgow I, Abrahamse H, et al. Annual report LINH 1997 (in Dutch). Utrecht: NIVEL, 1998.

13. Portegijs PJM. Somatization in frequent attenders of general practice. Ph.D. thesis: University of Maastricht, 1996.

14. Knottnerus JA, Metsemakers J, Höppener P, Limonard C. Chronic illness in the community and the concept of 'social prevalence'. Fam Pract 1992;9:15-21.

15. Kleinbaum DG, Kupper LL, Muller KE. Testing for the equality of two correlations, single sample test. Applied regression analysis and other multivariable methods. $2^{\text {nd }} \mathrm{ed}$. Boston: Kent Publishing Company, 1987: 92-93. 
16. Kirmayer LJ, Robbins JM, Dworkind M, Yaffe MJ. Somatization and the recognition of depression and anxiety in primary care. Am J Psychiatry 1993;150:734-741.

17. Morriss RK, Gask L, Ronalds C, Downes Grainger E, Thompson H, Goldberg D. Clinical and patient satisfaction outcomes of a new treatment for somatized mental disorder taught to general practitioners. Br J Gen Pract 1999;49:263-267.

18. Heywood PL, Blackie GC, Cameron IH, Dowell AC. An assessment of the attributes of frequent attenders to general practice. Fam Pract 1998;15:198-204.

19. Karlsson H, Joukamaa M, Lahti I, Lehtinen V, Kokki Saarinen T. Frequent attender profiles: different clinical subgroups among frequent attender patients in primary care. J Psychosom Res 1997;42:157-166.

20. van den Akker M, Buntinx F, Metsemakers JFM, Knottnerus JA. Morbidity in responders and non-responders in a register-based population survey. Fam Pract 1998;15:261-263.

21. Ormel J, van den Brink W, Koeter MW, et al. Recognition, management and outcome of psychological disorders in primary care: a naturalistic follow-up study. Psychol Med 1990;20:909-923.

22. Hansson L, Nettelbladt P, Borgquist L, Nordstrom G. Screening for psychiatric illness in primary care. A cross-sectional study in a Swedish health district. Soc Psychiatry Psychiatr Epidemiol 1994;29:83-87.

23. Goldberg D, Bridges K. Screening for psychiatric illness in general practice: the general practitioner versus the screening questionnaire. $J$ Royal Coll Gen Pract 1987;37:15-18.

24. Salmon P, Peters S, Stanley I. Patients' perception of medical explanations for somatisation disorders: qualitative analysis. BMJ 1999;318:372-376.

25. Knottnerus JA. Medical decision making by general practitioners and specialists. Fam Pract 1991;8:305-307.

26. Crisp A. The stigmatization of sufferers with mental disorders. BrJ Gen Pract 1999;49: 3-4.

27. Lidbeck J. Group therapy for somatization disorders in general practice: effectiveness of a short cognitive-behavioural treatment model. Acta Psychiatr Scand 1997;96:14-24.

28. Speckens AE, van Hemert AM, Spinhoven P, Hawton KE, Bolk JH, Rooijmans HG. Cognitive behavioural therapy for medically unexplained physical symptoms: a randomised controlled trial. BMJ 1995;311:1328-1332.

29. Kaaya S, Goldberg D, Gask L. Management of somatic presentations of psychiatric illness in general medical settings: evaluation of a new training course for general practitioners. Med Educ 1992;26:138-144.

30. Lin EHB, Katon W, Von Korff M, et al. Frustrating patients: physician and patient perspectives among distressed high users of medical services. J Gen Int Med 1991;6: 241-246.

31. Butler C, Evans M. The 'heartsink' patient revisited. BrJ Gen Pract 1999;49:230-233.

32. Mathers $\mathrm{N}$, Jones $\mathrm{N}$, Hannay D. Heartsink patients: a study of their general practitioners. Br J Gen Pract 1995;45:293-296. 
Chapter 4

Indicators of childhood adversity in somatisation in general practice

AF Schilte, PJM Portegijs, AH Blankenstein, MBF Latour, JTM van Eijk, and JA Knottnerus

Accepted for publication: Scandinavian Journal of Primary Health Care 2001 


\section{ABSTRACT}

Background In spite of its importance in somatisation, childhood adversity remains often beyond the scope of patient-doctor contacts. We studied whether medical and psychosocial factors indicate childhood adversity in somatising patients in primary care.

Methods Major problems in childhood, as well as medical and psychosocial variables, were investigated through retrospective questionnaires, and the GPs' registration, in 374 somatising frequent attenders in 27 general practices.

Results The questionnaire on childhood problems reflected acceptable validity against a structured interview in 77 patients (correlation 0.69); however, the item 'abuse' was underreported in the questionnaire. Four out of five patients reported one or more major childhood problems. Childhood adversity was indicated independently by chronic difficulties in present relations, and by genital-sexual symptoms of patients.

Conclusion When GPs want to take a more active approach towards somatisers, they may show interest in the childhood and life story of patients, especially when patients are known with chronic difficulties in relations and genital-sexual symptoms. 


\section{INTRODUCTION}

Patients with a tendency to present unexplained physical symptoms are mostly managed by their general practitioner (GP). GPs know their somatisers well; they have access to the medical history and are usually familiar with the psychosocial situation of patients. ${ }^{1-3}$ Childhood adversity is generally recognised as an important contributor to somatisation, resulting in frequent health problems and higher medical consumption. ${ }^{4,5}$ Other contributors to somatisation, such as life events, chronic difficulties, and impaired social support may also be associated with a difficult childhood. ${ }^{4-6}$ However important as an underlying cause of somatisation, childhood adversity often remains beyond the scope of patient-doctor contacts. Consultation time is limited in primary care and patients may consider their childhood to be unrelated to their present complaints, or they may "wall off the traumatic memories altogether. ${ }^{7,8}$ We studied whether childhood adversity can be surmised in somatising patients on the medical and psychosocial information generally available to GPs.

\section{METHODS}

\section{PRACTICES AND PATIENTS}

Twenty-seven practices at two locations in the Netherlands (Maastricht and Amsterdam) participated in this study. To diminish the influence of serious disease as a cause of symptoms, only younger patients between 20 and 45 years of age were included, without serious somatic (e.g., cancer) or mental disease (e.g., schizophrenia). We selected frequent attenders visiting their GP 15 or more times, on their own initiative, in the previous three years; estimated to be the $10 \%$ most frequent attenders in the Netherlands. ${ }^{9}$ Routine check-ups, on initiative of the GP, were not included in the count. In Maastricht, consultations were counted with special software in the computerised patient files, and in Amsterdam all patient charts were checked by hand. The frequent attenders received a postal screening questionnaire, listing the 37 somatisation symptoms and format of inclusion of DSM-III-R, Diagnostic Statistical Manual of Psychiatric Disorders, $3^{\text {rd }}$ revised edition. ${ }^{10}$ Patients were included when they had five or more symptoms (Somatic Symptom Index, SSI 5/5) over lifetime for men and women. ${ }^{1,2}$

\section{MEASUREMENTS}

The data in this study were extracted from the DSM-III-R questionnaire, from a second postal questionnaire, and from the patient charts. The questions on childhood problems (until the age of 18 ) were derived from an earlier study. ${ }^{4}$ 
Four mutually exclusive categories of childhood problems were addressed, each receiving a score between 0 (no) and 2 (severe), with a total score ranging between 0 and 8 . The first was parental 'lack of care' (with non-open-ended questions on death of parents, divorce of parents, nervous breakdown of parents, and living in an institution, foster home or boarding school). The second category was bearing too 'high responsibility' as a child (non-open-ended questions on child had definitely too heavy responsibilities in the family, such as running the household and bringing up siblings, or being overburdened by the problems of the parents). Traumatic events and situations were assessed with one openended question: Did you have other severe events or problems in your childhood? The answer to this question was coded in 'abuse' (sexual, physical, mental), or 'other severe events or problems' (including I do not want to describe the situation). Abuse was defined as any serious, threatening, and unwanted sexual experience or beating. An occasional non-threatening sexual experience with playmates, or non-threatening physical reprimand was not counted as abuse. ${ }^{11}$ To validate the postal questionnaire, 77 randomly drawn patients received a face-to-face, structured interview about their childhood at the patient's home (blinded to questionnaire).

Of the additional measures, the medical data consisted of the visit rate to the GP in the previous three years, the list of health problems, ${ }^{12}$ referrals, and the number of medicines used. Subjective health previous month $(0$ is very bad health, 100 is excellent health) was operationalised as the average of (a) a direct question on health, and (b) a combined score of six questions on the influence of symptoms on work, sleep, sports activities, social life, mood, and ruminating about being ill. Sick leave was expressed in weeks absent from work or household chores, due to illness in the previous six months. The psychosocial data consisted of DSM-III-R somatisation, ${ }^{10}$ SCL-90 Symptom Checklist, ${ }^{13}$ the number of life events last year, and chronic difficulties. ${ }^{14}$

\section{ANALYSIS}

Non-parametric tests were used throughout. The validity of the childhood questionnaire against the interview was assessed with correlation and regression coefficients. The Maastricht and Amsterdam data sets were analysed separately, to assess reproducibility of findings. To correct for confounding by gender, a partial correlation coefficient on the ranked data was used, in the case of continuous variables. The indicators with significant values in the bivariate analyses on the pooled data of both locations were entered in a multiple logistic regression model (backward elimination procedure). The dependent variable in the model was childhood adversity, dichotomised at the median of two major problems in childhood. 


\section{RESULTS}

Eight percent of the patients were frequent attenders without serious disease. The response rate to the somatisation questionnaire, after one reminder, was $67 \%$. Non-responders were relatively often unmarried, men, living single, with lower education, and relatively often they had psychological problems, especially addiction to alcohol or hard drugs. About half (51\%) of the respondents fulfilled the somatisation criterion of five or more symptoms lifetime, and 374 patients (203 in Maastricht and 171 in Amsterdam) participated in the study. Of these patients, 311 were women and 60 men, with a median age of 37 , and most patients had a low (47\%) to intermediate (43\%) level of education. Most patients (292 patients, i.e. 78\%) reported at least one problem in their childhood, and 216 (58\%) reported two or more problems (median 2, range 0-7). Abuse was reported by 50 patients ( 36 sexual abuse, 14 physical abuse, and 6 mental abuse), parental lack of care by 186 patients, high responsibility by 167 patients, and 188 patients reported other traumatic events or long-lasting difficulties in their childhood.

The overall correlation between the presence of childhood problems in the questionnaire versus the interview was 0.69 , with a regression coefficient of 0.75 , and a standard error of 0.08 . The separate dimensions lack of care and high responsibility correlated well ( 0.76 and 0.71 , respectively), while abuse and other trauma correlated moderately (both 0.40 ). Abuse, in particular, was underreported: of the 30 patients reporting serious abuse in the interview, only nine did so in the questionnaire, and of the 45 patients reporting no abuse in the interview, one did so in the questionnaire.

For the bivariate analyses see table 1 . Women reported more childhood problems, especially high responsibility and abuse. Of the other sociodemographic variables only living single was associated with a problematic childhood. The sociodemographic picture differed between the two locations: only in Maastricht did patients with lower education and work level report more childhood problems. We found no association of childhood adversity with length of the list of health problems, nor with the psychiatric disorders depression, anxiety disorders, and personality disorders in the registration of GPs. High consumption of medication and frequent visits to health care both indicated childhood adversity. An elevated number of DSM-III-R somatisation symptoms strongly indicated a problematic childhood, especially genital-sexual symptoms in women. SCL-90 sub-scales were consistently related to childhood problems, especially to high responsibility and abuse. Chronic difficulties, especially in relations, were strong indicators of childhood problems. Repeated analysis with childhood problems before the age of 10 did not yield different results.

The 16 variables showing a significant correlation in the bivariate analyses were entered in a logistic regression model (table 2). Chronic difficulties in rela- 
Table 1 Bivariate analyses of childhood problems with other variables. $\mathrm{N}=376$

\begin{tabular}{|c|c|c|c|c|c|}
\hline & \multirow[t]{2}{*}{ Scale } & \multirow[t]{2}{*}{ Median } & \multicolumn{3}{|c|}{ Childhood problems ${ }^{\mathrm{a}}$} \\
\hline & & & $\begin{array}{l}\text { Maastricht } \\
\mathrm{N}=203\end{array}$ & $\begin{array}{l}\text { Amsterdam } \\
N=173\end{array}$ & $\begin{array}{l}\text { Total } \\
N=376\end{array}$ \\
\hline \multicolumn{6}{|l|}{ Sociodemographic data } \\
\hline Age & $20-45$ & 37 & -0.06 & 0.09 & 0.01 \\
\hline Female gender ${ }^{b}$ & dich. $^{\text {a }}$ & - & $p=0.05$ & ns & $p=0.05$ \\
\hline Immigrant status ${ }^{b}$ & dich. & - & ns & ns & ns \\
\hline Level of education & $1-3$ & 2 & $-0.14^{\star}$ & $0.13^{\wedge}$ & 0.00 \\
\hline Level of work & $1-3$ & 1 & $-0.26^{\star \star \star}$ & $0.15^{\wedge}$ & -0.06 \\
\hline Marital status: unmarried ${ }^{\mathrm{b}}$ & dich. & - & ns & $p=0.06$ & $\mathrm{p}=0.08$ \\
\hline Living single ${ }^{b}$ & dich. & - & ns & $p=0.03$ & $p=0.02$ \\
\hline Health insurance: public ${ }^{b}$ & dich. & - & ns & - & - \\
\hline \multicolumn{6}{|l|}{ Medical data } \\
\hline Consultations with GP (3 years) & $15^{\mathrm{C}}-77$ & 20 & -0.02 & 0.00 & -0.02 \\
\hline Health problems ${ }^{d}$, all problems & $0-21$ & 7 & -0.06 & - & - \\
\hline - Psychosocial problems & $0-7$ & 1 & 0.00 & - & - \\
\hline - Depression ${ }^{b} N=21$ & dich. & - & ns & - & - \\
\hline - Anxiety disorders ${ }^{b} \mathrm{~N}=30$ & dich. & - & ns & - & - \\
\hline - Personality disorders ${ }^{b} \mathrm{~N}=7$ & dich. & - & ns & - & - \\
\hline Visits to health care ( 6 months) & $0-83$ & 2 & 0.11 & 0.09 & $0.11^{*}$ \\
\hline Number of medicines ( 6 months) & $0-9$ & 2 & 0.09 & $0.20^{\star \star}$ & $0.14^{\star \star}$ \\
\hline \multicolumn{6}{|l|}{ Subjective health and sick leave } \\
\hline Subjective health (previous month) & $0-100$ & 42 & -0.11 & -0.09 & $-0.10^{\star}$ \\
\hline Sick leave (previous six months) & $0-26$ & 1 & 0.11 & 0.05 & $0.10^{\wedge}$ \\
\hline \multicolumn{6}{|l|}{ Psychosocial data } \\
\hline Unexplained symptoms, DSM-III-R & $5^{c}-19$ & 7 & $0.28 * * *$ & $0.22^{\star *}$ & $0.24 * * *$ \\
\hline - Gastro-intestinal symptoms & $0-6$ & 2 & 0.09 & $0.18^{*}$ & $0.13^{* *}$ \\
\hline - Genital-sexual symptoms & $0-8$ & 1 & $0.24^{* *}$ & $0.18^{*}$ & $0.24 * * *$ \\
\hline - Pseudo-neurological symptoms & $0-12$ & 1 & $0.15^{*}$ & 0.05 & $0.10^{*}$ \\
\hline - Cardio-respiratory symptoms & $0-4$ & 2 & $0.12^{\wedge}$ & 0.05 & 0.08 \\
\hline - Muscular symptoms & $0-5$ & 1 & 0.05 & 0.00 & 0.02 \\
\hline Somatisation, SCL-90 & $0-48$ & 21 & $0.20^{* *}$ & $0.20^{\star}$ & $0.19 * * *$ \\
\hline Depression, SCL-90 & $0-64$ & 23 & $0.18^{\star}$ & $0.21^{\star \star}$ & $0.19^{\star \star \star}$ \\
\hline Anxiety + agorafobia, SCL-90 & $0-68$ & 13 & $0.17^{\star \star}$ & $0.18^{*}$ & $0.17^{\star \star}$ \\
\hline Life events last year, all events & $0-30$ & 2 & $0.14^{*}$ & $0.21^{* *}$ & $0.17^{\star *}$ \\
\hline Life events last year, negative events & $0-18$ & 1 & $0.20^{\star \star}$ & $0.19^{*}$ & $0.20 * * *$ \\
\hline Chronic difficulties in relations & $0-24$ & 3 & $0.30^{\star \star \star}$ & $0.28^{* * *}$ & $0.29 * * *$ \\
\hline Chronic difficulties in situations & $0-27$ & 3 & $0.16^{*}$ & 0.10 & $0.14^{*}$ \\
\hline Social support & $0-100$ & 42 & $-0.25^{* * *}$ & -0.10 & $-0.18^{* \star}$ \\
\hline
\end{tabular}

a. Partial correlation (corrected for gender) on the ranked data for ordinal and continuous variables, and Mann-Whitney $U$ tests (not corrected for gender) for dichotomous (dich) variables

b. In dichotomous variables the category with highest degree of youth problems is indicated

c. Patient selection procedure: minimum of 15 consultations and 5 unexplained symptoms

d. List of medical problems was only available in Maastricht

^: $p<0.10 ;{ }^{*}: p<0.05 ;{ }^{* *}: p<0.01 ;{ }^{* \star}: p<0.001$ 
Table 2 Logistic regression model (backward elimination) on a problematic childhood, dichotomised at median score of two problems.

\begin{tabular}{llllll}
\hline & Scale & \multicolumn{2}{l}{ Full model } & \multicolumn{2}{l}{ Reduced model } \\
& & & & & \\
& & $\mathrm{OR}^{\mathrm{a}}$ & signif. & $\mathrm{OR}^{\mathrm{a}}$ & signif. \\
\hline Chronic difficulties in relations & $0-27$ & 1.21 & 0.000 & 1.16 & 0.000 \\
Genital-sexual somatisation symptoms & $0-8$ & 1.39 & 0.009 & 1.41 & 0.002 \\
SCL-90 depression & $0-64$ & 0.96 & 0.073 & & \\
Living single & dich. & 2.42 & 0.077 & & \\
Chronic difficulties in situations & $0-24$ & 0.91 & 0.109 & & \\
Negative life events previous year & $0-18$ & 1.20 & 0.115 & & \\
SCL-90 somatisation & $0-48$ & 1.04 & 0.205 & & \\
Visits to health care & $0-83$ & 1.01 & 0.261 & & \\
Female gender & dich. & 1.66 & 0.286 & & \\
Social support & $0-100$ & 0.76 & 0.399 & & \\
SCL-90 anxiety + agoraphobia & $0-68$ & 1.01 & 0.437 & & \\
Number of medicines & $0-9$ & 1.04 & 0.728 & & \\
Subjective health & $0-100$ & 1.00 & 0.744 & & \\
Gastro-intestinal somatisation symptoms & $0-6$ & 1.02 & 0.847 & & \\
Pseudo-neurological somatisation symptoms & $0-12$ & 0.98 & 0.899 & & \\
Constant & & & 0.045 & & 0.000 \\
\hline
\end{tabular}

a. Odds Ratio per point of change on the scale

tions and DSM-III-R genital-sexual symptoms independently indicated childhood problems. To test whether important variables showed a different picture in women and men, we added to the reduced model the variable gender and all interaction variables with gender. None of these interactions added significantly to the model.

For illustration, we describe one low- and one high-risk subject, on the 10th and the 90th percentiles, with the expected probabilities of childhood adversity. The low-risk subject was a woman 37 years old, living with her husband and children. She had five lifetime somatisation symptoms, and no chronic difficulties in relations. The model predicted a 35\% chance for her on childhood problems; she reported no problems in childhood. The high-risk subject was a woman of 39, living with partner and children. She had 13 somatisation symptoms (including excessive, irregular menstrual bleeding, menstrual pain, and painful intercourse), and she reported chronic problemss with her partner, parents, parents-in-law, and her sister. The model predicted an $83 \%$ chance on childhood problems. She reported the following problems: at age 15 her mother had breast cancer, which resulted in her running the household, and serving as emotional anchor for her mother, and she was raped by a stranger at age 16. She never disclosed her childhood story to her GP. 


\section{DISCUSSION}

Four out of five frequent attenders, with unexplained symptoms, reported at least one major problem in their childhood. Childhood adversity was indicated by long-term difficulties in relations and by unexplained genital-sexual symptoms. Subjective and objective health did not indicate childhood adversity.

Our study is limited to somatising patients in general practice, between 20 and 45 years of age, and our findings do not automatically extend to the whole community. Nevertheless, the group under study is a clinically relevant one, since most of these patients, as well as their physicians, feel a need of changing the purely medical approach. ${ }^{15,16}$ It is striking that most participants were female. The main explanation for our excess of women is that we decided to use the SSI $5 / 5$ criterion instead of the SSI 4/6 ( 4 symptoms for men, 6 for women ${ }^{1}$ ). Additionally, women attended their GP more frequently, and men dropped out more often by not answering the questionnaires. In the sample under study, women, more often than men, reported a difficult childhood, especially abuse and bearing high responsibility. ${ }^{17}$

The aetiological question whether childhood adversity is a cause of somatisation can only be answered in (prospective) community-based surveys, case control designs, or well-performed qualitative studies; $5,11,17$ this question is therefore not addressed here. We found fairly good overall agreement between the questionnaire and the interview on childhood problems, similar to other authors ${ }^{18}$ however, care has to be taken when interpreting our figures on abuse. Abuse was disclosed more easily through interview, and GPs are advised to conduct a careful, none-blaming interview style in disclosing sensitive childhood memories. $7,11,15,17$

Clearly visible in our data is the strong association between a problematic childhood, and difficulties in relations in later life. Other authors report childhood aetiologies for many chronic problems in adulthood as well, especially in relations and social functioning. ${ }^{19}$ Only a minority of patients in our study reported an isolated problem in childhood; social impairment in adult life seems rather a result of a pathogenic family structure with more than an incidental traumatic experience. ${ }^{7}$

Patients with unexplained somatic symptoms often resist being referred to psychiatrists or psychologists, because they generally do not interpret their complaints as resulting from mental problems. ${ }^{7}$ Next to identifying treatable somatic and psychiatric conditions, an important task of GPs is to understand the complaints as part of the life story of the patient. Recent theories about the beneficial effect of disclosure of traumatic memories are especially relevant to childhood experiences. ${ }^{20}$ GPs should take into account that consultations may demand more time when important memories are brought up by patients, and GPs should 
be careful not to expose large numbers of patients with a vulnerable childhood at the same time, without being able to manage them. When GPs do not consider psychological issues to be part of their task, they may cooperate with a psychologist, or counsellor. However, a purely medical approach, without being open for the life story of patients, may also have consequences: it affirms patients in their futile search for an organic explanation to their complaints. ${ }^{7,15}$

\section{CONCLUSIONS}

When GPs want to take a more active approach towards somatisers they may facilitate disclosure of childhood trauma when patients are known to have had long-term difficulties in relations and genital-sexual symptoms. An effective approach of patients with a tendency to somatise distress seems to be particularly important in primary care, since most of these patients are solely managed by their GP. 


\section{REFERENCES}

1. Escobar JI, Rubio-Stipec M, Canino G, Karno M. Somatic symptom index (SSI): a new and abridged somatization construct. Prevalence and epidemiological correlates in two large community samples. J Nerv Ment Dis 1989;177:140-146.

2. Portegijs PJM, van der Horst FG, Proot IM, Kraan HF, Gunther NC, Knottnerus JA. Somatization in frequent attenders of general practice. Soc Psychiatry Psychiatr Epidemiol 1996;31:29-37.

3. Huygen F. Family medicine- the medical life history of families. Nijmegen: Dekker \& van de Vegt, 1978.

4. Portegijs PJM, Jeuken FM, van der Horst FG, Kraan HF, Knottnerus JA. A troubled youth: relations with somatization, depression and anxiety in adulthood. Fam Pract 1996;13:1-11.

5. Craig TK, Boardman AP, Mills K, Daly Jones O, Drake H. The South London Somatisation Study. I: Longitudinal course and the influence of early life experiences. Br J Psychiatry 1993;163:579-588.

6. Brown GW, Harris TO. Social origins of depression: A study of psychiatric disorder in women. London: Tavistock Publications, 1978.

7. Arnold RP, Rogers D, Cook DA. Medical problems of adults who were sexually abused in childhood. BMJ 1990;300:705-708.

8. Kirmayer LJ, Robbins JM. Patients who somatize in primary care: a longitudinal study of cognitive and social characteristics. Psychol Med 1996;26:937-951.

9. de Bakker D, Kulu-Glasgow I, Abrahamse H, et al. Annual report LINH 1997 (in Dutch). Utrecht: NIVEL, 1998.

10. American Psychiatric Association. Diagnostic and statistical manual of mental disorders, $3^{\text {rd }}$ ed. revised. Washington DC: American Psychiatric Association, 1987: 261-264.

11. Draijer N. Sexual abuse of girls by relatives: A national study of prevalence, nature, family backgrounds, emotional significance and psychic and psychosomatic consequences (in Dutch). The Hague: Ministerie van Sociale Zaken en Werkgelegenheid, 1988.

12. Metsemakers JFM, Knottnerus JA, van Schendel GJ, Kocken RJJ, Limonard CBG. Unlocking patients' records in general practice for research, medical education and quality assurance: the Registration Network Family Practices. Int J Biomed Comput 1996;42:43-50.

13. Derogatis L, Cleary P. Confirmation of the dimensional structure of the SCL-90: a study in construct validation. J Clin Psychol 1977;33:981-989.

14. Hendriks A, Ormel J, Willige G. Long-term difficulties measured with self-report questionnaire and semi-structured interview (in Dutch). Gedrag en Gezondheid 1990;18:273-283.

15. Salmon P, Peters S, Stanley I. Patients' perception of medical explanations for somatisation disorders: qualitative analysis. BMJ 1999;318:372-376. 
16. Schilte AF, Portegijs PJM, Blankenstein AH, Knottnerus JA. Somatisation in primary care: clinical judgement and standardised measurement compared. Soc Psychiatry Psychiatr Epidemiol 2000;35:276-282.

17. Hamberg K, Johansson EE, Lindgren G. 'I was always on guard'-an exploration of woman abuse in a group of women with musculoskeletal pain. Fam Pract 1999;16: 238-244.

18. Bernstein D, Fink L, Handelsman $L$, et al. Initial reliability and validity of a new retrospective measure of child abuse and neglect. Am J Psychiatry 1994;151:1132-1136.

19. Cahill C, Llewelyn P, Pearson C. Long-term effects of sexual abuse which occurred in childhood: a review. Br J Clin Psychology 1991;30:117-130.

20. Smyth JM. Written emotional expression: effect sizes, outcome types, and moderating variables. J Cons Clin Psychol 1998;66:174-184. 

Chapter 5

A disclosure intervention for general practice patients with somatisation: an illustration with three case histories. 


\section{ABSTRACT}

Background There is a need for effective therapeutic strategies for general practice patients with somatisation. Disclosure seems a promising and acceptable method.

Methods A disclosure intervention was developed, building on experiences in an earlier study and on suggestions in the literature. The intervention consisted of two meetings between the 'disclosure GP' and the patient, and an additional joint consultation including the patient, his own GP, and the disclosure GP. The intervention is illustrated in three case histories.

Results Two of the three patients completed the disclosure intervention and joint consultation, and the communication with their GPs improved. None of the three patients improved in symptomatology in two years of follow-up.

Conclusion Setting modest goals saves GPs and somatising patients from disappointment. A disclosure intervention may improve the communication between doctor and patient. 


\section{INTRODUCTION}

Individuals with traumatic experiences are at risk of physical and mental health problems. ${ }^{1,2}$ The consequences of childhood sexual abuse, symptoms of posttraumatic stress as a result of war circumstances, and the detrimental effects of avoiding grief after bereavement are well known. ${ }^{3-5}$ There is a need for effective therapeutic strategies in primary care for patients with symptoms related to emotionally important events. ${ }^{6-8}$ Recently, studies have been published on so-called disclosure interventions. ${ }^{9}$ These interventions consist of assignments to write or speak about traumatic and emotionally upsetting events. Typically, disclosure released stress, improved the function of the immune and autonomic nervous systems, improved subjective health, and reduced the use of health care services. ${ }^{9-11}$ These positive effects can be explained with the theory of 'inhibition and psychosomatics', which is linked to Selye's general stress theory and psychodynamic ideas on catharsis. ${ }^{12-14}$ According to these theories, stress accumulates when traumatic experiences are concealed. ${ }^{15,16}$ Even when a person no longer ruminates about the event, stress is created by subconscious suppression of the traumatic event. The resulting chronically increased stress levels will then lead to exhaustion and to stress-related complaints and disease. Disclosure is part of normal social interaction and most cultures have some kind of institutionalised practice to promote disclosure in certain situations; for example, confession in Catholic belief and group confession as treatment of disease in African and Asian cultures. ${ }^{17,18}$ Mourning customs in different societies can also be understood as means of creating an outlet for emotions of grief and loss.

Patients with somatic symptoms related to emotional events and circumstances will present their somatisation symptoms especially to their primary care physician. ${ }^{6}$ Whether disclosure techniques can strengthen the therapeutic arsenal of GPs in somatisation remains to be studied. In this chapter we will elucidate the use of a disclosure intervention for somatising patients in general practice. First we will describe the intervention as developed by us, and then illustrate its application in three case histories.

\section{DISCLOSURE INTERVENTION}

The disclosure intervention consisted of two meetings of the patient and a trained 'disclosure GP', followed by a joint consultation with the patient, his own GP, and the disclosure GP in case important information was disclosed. The model with two disclosure meetings was derived from an earlier study. ${ }^{19}$ The first and second meetings were a week apart and lasted two hours and one hour respectively. Patients were invited to speak about emotionally important events 
in their life. If these were not mentioned spontaneously, the disclosure GP asked open questions about traumatising events and about family life, health, and work situations. A structured, childhood-trauma questionnaire was also used. ${ }^{20}$ The disclosure GP applied an open, evocative interview style, using non-directive consultation techniques common to most GPs, such as the use of open questions, reflection of emotions, inquiry into vague or unclear statements, and summarising. The attitude of the intervention GP had to reflect sincere interest in the patient's story, and followed the patient's frame of reference. ${ }^{21}$ Towards the end of the first meeting, the researcher asked a set of screening questions for depressive, anxiety, and somatoform disorders (DSM-IV). ${ }^{22}$ Between the two meetings patients were asked to keep an experience-sampling diary for six days, in which they reported thoughts, emotions, physical sensations, and activities, at different moments of the day ${ }^{23}$ In the second meeting the results of the patient's life story, the DSM-IV screening, and the diary were discussed, and patients wrote their own summary of the two meetings, which served as an agenda for the joint consultation.

\section{CASE 1}

A married woman, 37 years of age, with an eight-year-old child stated that she felt exhausted and had not had any energy for the last year, to do her work as a cafeteria manager and in her household. Some time before, she had mentioned this problem to her GP, along with several other complaints (migraine, palpitations, stomach pain, trouble keeping her weight under control). Her GP seemed to be in a hurry and prescribed a painkiller. She did not visit her doctor again with her story, because she 'did not want to disturb the doctor, because it is a mental thing.' When asked about her life, she told about wishing for a child since her early twenties. After six years of infertility treatment, she became pregnant and gave birth to a healthy daughter. During the pregnancy she was always afraid that something would happen to the unborn child, and this fear continued, after giving birth, with restlessness and unhappiness. She more or less recovered from these depressed feelings after three months, although she kept worrying about her child. Four years ago, her husband fractured a vertebrae in his lower back on the slide at the playground, and has been on partial disability pension ever since. Their income went down and she went through another depressive period. She had to find work and started her present job as a cafeteria manager, working different shifts. Her husband was mainly concerned with his own recovery and they had a difficult period in their marriage. At present, the main problem between her and her husband is their sex life. Over the last two years, her libido has diminished, without clear reason, but to keep her husband satisfied, she gives 
in once in a while. When asked about her childhood, she explained that she never felt close to her mother and, even now, does not know how to get support from her. Her sister is much closer to their mother; her sister went through a divorce and a depression, which took her about a year to recover from, but she recovered and remarried.

The DSM-IV screening revealed a major depression with symptoms of anxiety. The experience-sampling diary confronted her with her anger about her tiredness and lack of initiative to change her situation. At the second meeting, the subject of discussion was primarily her depressed state instead of the unexplained symptoms discussed in the first meeting. After writing her own short summary of the two meetings, she decided to visit her GP for help.

In the joint consultation, her sense of exhaustion got full attention. At first, the GP did not recognise the depression, but after discussing her symptoms extensively, she received pharmacological treatment for depression (amitryptiline $75 \mathrm{mg}$ at bedtime).

Over the following two years, she reported (at 6, 12 and 24 months) that her migraines had worsened, but the communication with her GP had improved a lot and she was visiting him regularly. She tried psychotherapy, but stopped after a couple of months without clear reason. Another antidepressant (paroxetine $20 \mathrm{mg}$ twice daily) partially improved her depression.

\section{CASE 2}

The second case is about a married woman, 40 years of age, with one teenage child, who told her story in a chaotic way, skipping from one subject to another, leaving her sentences half finished. She wore a brace to support her left arm. Her story started seven years ago, after undergoing a first-rib resection for complaints of weakness in her left arm. This resulted in a frozen shoulder, which, after several operations, was diagnosed as a posttraumatic dystrophy. She has had a lot of physiotherapy over the past years, and recently started treatment with sorbitol infusions. She had just finished a rehabilitation day-programme, which was not successful. In spite of all this treatment her fingers, hand, and arm have become progressively painful, cold, and weak. 'This arm looks ok, but why does it bother me constantly?', she asked. The left side of her body has got weaker and weaker, and she also has increasing difficulty in walking. She has also suffered from alternating strabismus of both eyes since the age of 17 , which forced her to stop her law studies. Over the years her eyes have been operated on eight times, without success. Her medical history further mentions headaches since the age of 17 , a complicated recovery after an appendicitis, and the removal of her uterus and ovaries because of multiple ovarian cysts and menstrual pains. At the time of 
the interview she was seeing an orthopaedic surgeon, an anaesthesiologist, a physiotherapist, and a psychologist, and taking two different painkillers. She felt frustrated that her body continuously bothers her. 'I am now 40, what to expect in the future?..., I am constantly acting..., behaving like all is normal. I don't want to be a sad case for other people.' Her GP knew her medical history well. She was ambivalent about her relation with her GP: 'He knows me very well, but he is always so busy that I cannot really ask him those questions' (about her worries of becoming a complete invalid). When asked about her childhood, she explained that her father had cancer of the larynx and died when she was 21 . She did not want to say more about her childhood, but continued that both her parents involved her a lot in their problems. In the second meeting, she disclosed the secret of her childhood: her father was an alcoholic throughout her youth, and the family always covered up his addiction, hiding it from the outside world. She still wishes she could ask her father, 'Why alcohol? Why didn't you do something about it?' Like the alcohol, the father's cancer was also concealed from outsiders. Otherwise her childhood memories are vague and scattered. So far she had told this secret to only one person before, the rehabilitation programme social worker. At the joint consultation, she disclosed her childhood story again and was able to weep for the first time since her father's death. One week later she also told her husband her story and felt a lot better afterwards.

Her physical complaints, however, did not change over the following two years. She kept using medication and seeing different specialists and her physiotherapist. The communication with her GP has improved: although she does not see him often, she knows that he is there for her when needed.

\section{CASE 3}

The third case history is that of a married man, 41 years old, with two teenaged children, who described a long history of pain in his lower back, radiating to his left leg. Two years ago he had seen a neurologist, but in the subsequent CT-scan they did not find a herniated disc. A year ago an anaesthesiologist performed a nerve block in his back ('they burned a nerve'), but the pain subsequently became worse. A transdermal electric nerve stimulator (TENS) partially improved his pain last year. He has also consulted a range of alternative therapists over the years, without finding relief from the pain. For about a year he was on sick leave from his shift-work job as an operator in a chemical plant. Recently, he has started work again, in spite of the pain. When he was forced to stay home, he was grumpy and easily irritated about small things; his marriage has been through a difficult period in the last two years. The pain increases when he is irritated or tired. His tense facial expression relaxed when he spoke about the past. Ten years 
ago, when he was still healthy, he ran his own business in the building trade. $\mathrm{He}$ was able to work day and night and earn a lot of money. He had to give up this work because his knees started bothering him, resulting in a meniscus operation. He does not see his general practitioner often. 'This man cannot do much for me; they don't know what causes the pain.' When asked about his childhood, he said that he only remembers that he had to work very hard. They had a restaurant at home, and from the age of eight he had to work daily, washing dishes, peeling potatoes, and serving food. When he was 11 he worked daily till one or two a.m., untill all guests had left. He does not remember any warmth from his parents, but they did give him a lot of money, which he mostly spent on beer. At the age of 19 he left home and joined the marine, and when he came back he married and started his business. Four years ago both his parents died within one year; in that period, the pain in his back started.

The experience-sampling diary brought forward the pain which bothers him day and night, causing disturbed sleep, tiredness, and irritated moods. But when asked whether he felt depressed or anxious, he denied it and did not fulfil the criteria for a depression or other psychiatric disorder. He did not want to participate in the joint consultation. During the two years of follow-up, the patient reported that his situation remained more or less the same; his relationship with his GP also remained ambivalent.

\section{DISCUSSION}

A non-directive consultation style has been part of GP's formal training and continuous medical training packages over the last two decades in the Netherlands. ${ }^{21,24}$ Many GPs already apply disclosure-like techniques in their daily practice. In somatisation especially, attention is often focussed largely on the physical complaints of the patient, and additional disclosure may be indicated.

When patients are invited to discuss psychosocial aspects, extra time needs to be invested at first. A quick recovery is not easily reached in chronically somatising patients. The three patients in this chapter did not (fully) recover from their symptoms over a two-year period. Their psychosocial and health problems, accumulated over a lifetime, led to chronic symptoms flaring up in periods of stressful circumstances. Communication with their GPs, however, improved significantly in two of the three patients during follow-up. Setting less ambitious goals saves GPs and patients from disappointment. Often, the only rewarding results are improved communication between doctor and patient, extra social support, and prevention of (some) unnecessary treatments and referrals.

Although many examples exist of favourable effects of disclosure interventions in different groups of patients, ${ }^{10}$ the effect of disclosure has never been 
studied in somatisation. Methods aimed at disclosure of emotionally important events seem a promising alternative in patients with somatisation symptoms in general practice. 


\section{REFERENCES}

1. Fry R. Adult physical illness and childhood sexual abuse. J Psychosom Res 1993;37: 89-103.

2. Cahill C, Llewelyn P, Pearson C. Long-term effects of sexual abuse which occurred in childhood: a review. Br J Clin Psychology 1991;30:117-130.

3. Draijer N. Sexual abuse of girls by relatives: A national study of prevalence, nature, family backgrounds, emotional significance and psychic and psychosomatic consequences (in Dutch). The Hague: Ministerie van Sociale Zaken en Werkgelegenheid, 1988.

4. Potts MK. Long-term effects of trauma: post-traumatic stress among civilian internees of the Japanese during World War II. J Clin Psychol 1994;50:681-698.

5. Pennebaker JW, Mayne TJ, Francis ME. Linguistic predictors of adaptive bereavement. J Pers Soc Psychol 1997;72:863-871.

6. Gallo JJ, Coyne JC. The challenge of depression in late life. JAMA 2000;284:15701572.

7. van den Akker M, Mol S, Metsemakers J, Dinant GJ, Knottnerus JA. Barriers in the care of patients who have experienced a traumatic event: the perspective of general practice. Fam Pract 2001;18:214-216.

8. Di Blasi Z, Harkness E, Ernst E, Georgiou A, Kleijnen J. Influence of context effects on health outcomes: a systematic review. Lancet 2001;357:757-762.

9. Pennebaker JW, Susman JR. Disclosure of traumas and psychosomatic processes. Soc Sci Med 1988;26:327-332.

10. Smyth JM. Written emotional expression: effect sizes, outcome types, and moderating variables. J Cons Clin Psychol 1998;66:174-184.

11. Pennebaker JW. Writing about emotional experiences as a therapeutic process. Psychol Sci 1997;8:162-166.

12. Pennebaker JW, Hughes CF, O'Heeron RC. The psychophysiology of confession: linking inhibitory and psychosomatic processes. J Pers Soc Psychol 1987;52:781-793.

13. Selye H. The stress of life. New York: McGraw-Hill, 1976.

14. Scheff TJ. Catharsis in healing, ritual and drama. Berkeley: University of California Press, 1979.

15. Rimé B, Mesquita B, Philippot P, Boca S. Beyond the emotional event: six studies on the social sharing of emotion. Cogn Emotion 1991;5:435-465.

16. Wegner DM. Ironic processes of mental control. Psychol Rev 1994;101:34-52.

17. Frank JD. Persuation and healing. Baltimore: John Hopkins Press, 1961.

18. Turner V. The forest of symbols: Aspects of Ndembu ritual. New York: Cornell University Press, 1967.

19. Portegijs PJM. Somatization in frequent attenders of general practice. Ph.D. thesis: University of Maastricht, 1996. 
20. Portegijs PJM, Jeuken FM, van der Horst FG, Kraan HF, Knottnerus JA. A troubled youth: relations with somatization, depression and anxiety in adulthood. Fam Pract 1996;13:1-11.

21. Schouten JAM. Hoofdstuk 5: Het exploratieve gesprek. Anamnese en advies, nieuwe richtlijnen voor de informatie uitwisseling tussen arts en patiënt. $2^{\text {nd }}$ edition: Samsom Stafleu, 1988.

22. American Psychiatric Association. Diagnostische criteria van de DSM-IV, beknopte handleiding, Nederlandse vertaling. Lisse: Swets \& Zeitlinger, 1995.

23. de Vries MW, ed. The experience of psychopathology: investigating mental disorders in their natural settings. Cambridge UK: Cambridge University Press, 1992.

24. Jenner JA, van der Meer K, van Os TWDP, van den Brink RHS, Tiemens BG, Ormel J. Psychosociale klachten in de huisartspraktijk, een trainingsprogramma voor huisartsen (INSTEL). Groningen: Van Gorcum, Assen, 1995. 
Chapter 6

Is disclosure of emotionally important events effective in somatisation in primary

care? A randomised-controlled trial.

AF Schilte, PJM Portegijs, AH Blankenstein, HE van der Horst, MBF Latour, JTM van Eijk, and JA Knottnerus

Accepted for publication: British Medical Journal 2001 


\begin{abstract}
Background A purely medical approach is insufficient when patients present somatisation symptoms in primary care. Favourable effects of disclosure of emotionally important events have been shown in different populations, on health and medical consumption. We studied whether disclosure improves subjective health, and reduces medical consumption and sick leave in somatising patients in general practice.

Methods A randomised-controlled trial was conducted of frequently attending somatisers in ten general practices. Patients in the intervention group were visited two to three times and were invited to disclose emotionally important events in their life. Patients filled in follow-up questionnaires after 6,12 and 24 months, on the main outcome variables: medical consumption (medication and health care visits), subjective health, and sick leave.

Results Of 161 patients included, 137 completed the trial (85\%). Both groups were comparable at baseline. No effect of the intervention was found on the main outcome measures at different moments of follow-up. The difference, if any, was in the opposite direction: intervention patients had more health care visits (1, CI: $-4,6)$, lower subjective health $(3.6$, scale $0-100$, CI: $-11.2,4.3)$, and longer sick leave $(-1, \mathrm{CI}:-1,3)$ at two-year follow-up than control patients. Patients often had a depression or anxiety disorder for which they were not receiving adequate care.
\end{abstract}

Conclusion Although well-received by patients and their physicians, an intervention focussed on disclosure did not show any effect in somatising patients in general practice. 


\section{INTRODUCTION}

Patients presenting functional complaints at consultation hours in general practice are very common. ${ }^{1,2}$ Many patients only incidentally present functional complaints, whereas some exhibit long-term tendencies to seek medical attention for unexplained symptoms, often in relation to psychological stress, depression, or anxiety. ${ }^{3,4}$ Few patients in primary care are seriously disabled through a long history of many unexplained symptoms, defined as somatisation disorder. ${ }^{1,5}$ In this article we adopted Lipowski's definition', defining somatisation as: 'A tendency to experience and express somatic distress and symptoms unaccounted for by pathological findings, to attribute them to physical illness, and to seek medical help for them. It is often assumed that somatisation becomes manifest in response to psychosocial stress brought about by life events that are personally stressful to the individual.'

A purely medical approach is clearly insufficient when patients present somatisation symptoms, and there is a need for feasible psychological methods which are acceptable to patients. The relations between traumatic experiences in childhood and later somatisation are generally recognised, ${ }^{6-8}$ and physicians commonly inquire after life events and stressful circumstances, when a psychosocial explanation is sought for in case of unexplained symptoms. For most patients sharing emotions with someone is acceptable and self-disclosure is culturally embedded. ${ }^{9}$ Moreover, an increasing body of literature shows favourble health effects of emotional expression techniques, or 'disclosure', on subjective health, number of doctor visits, stress-related immune measures, and physical symptoms in healthy people. ${ }^{10-12}$ However, the effectiveness of disclosure of emotionally important events in somatisation has never been evaluated in a randomised-controlled trial.

We developed an intervention focussing on disclosure of traumatic experiences for patients with a somatisation tendency in primary care. We studied the effect of adding the disclosure intervention to regular care, on medical consumption, subjective health, and sick leave. In addition, we studied the effect on quality of life, severity of symptoms, patient's perception of support, and physician's judgement of somatisation.

\section{METHODS}

A randomised-controlled trial was conducted in ten general practices cooperating in the Family Practice Registration Network (RegistratieNetwerk Huisartspraktijken, $\mathrm{RNH}^{13}$ ) in the region of Maastricht in the Netherlands. In the trial usual care was compared with usual care plus the disclosure intervention. 
Randomisation was performed at the level of individual patients in the ten practices. Additionally, another nine randomly-selected practices (5 in Maastricht, and 4 in a sister project in Amsterdam) served as an extra control group to control for contamination of the effect of the trial as a whole; in these practices no intervention was introduced. The protocol was approved by the ethics committee of the Academic Hospital Maastricht and the University of Maastricht.

\section{RECRUITMENT OF PATIENTS}

Frequently attending patients, between 20 and 45 years of age, received a postal questionnaire inquiring about somatisation symptoms they had experienced in their life. Frequent attendance was defined as 15 contacts or more with their physician, on the patient's initiative, in the previous three years. Routine examinations on the initiative of the physician (e.g., cervical smears, blood pressure check-ups) were not included in the consultation count. We estimated this would select the $10 \%$ most frequently attending patients of this age group in the Netherlands. ${ }^{14}$ The somatisation questionnaire, developed by the authors and validated in a pilot study, contained the 37 somatisation symptoms listed in DSM-III-R, with the pertinent follow-up questions. ${ }^{5}$ Symptoms counted when not explained by organic disease and use of medicines, alcohol, or drugs (based on the physical examination of the physician, as reported by the patient in the questionnaire). Frequently attending patients with five or more somatisation symptoms were eligible for the study. $1,2,15,16$

Patients with the following serious somatic or mental diseases were excluded: cancer, AIDS, rheumatoid arthritis, multiple sclerosis, dementia, schizophrenia, mental retardation, and psychosis. Patients with other chronic diseases, such as asthma, osteoarthritis, or cardiovascular diseases were not excluded to maintain a high generalisability for patients in primary care. Patients with insufficient knowledge of the Dutch language to fill in questionnaires were excluded.

\section{TREATMENT CONDITIONS}

Control patients were treated by their physician in the usual way. Intervention patients received, in addition to the physician's care, the disclosure intervention, which consisted of two meetings of the patient with a trained 'disclosure doctor' at the patient's home. When important information was disclosed and if the patient agreed, an additional joint consultation including the patient's own physician was planned as well. The first meeting had to be within two weeks after inclusion in the trial and lasted two hours; the second meeting, one week later, took one hour, and the optional joint consultation, one week later again, took 30 minutes to one hour. In the meetings patients were invited to disclose emotionally important events in their life. When not mentioned spontaneously, the 
disclosure doctor asked open questions about family life, health, work situation, and childhood. A structured, childhood-trauma questionnaire was used. ${ }^{7}$ The disclosure doctor applied an open, evocative interview style, using non-directive consultation techniques common to most practitioners, such as open questions, reflection of emotions, inquiry on vague or unclear statements, and summarising. The disclosure doctor reflected sincere interest in the patient's story, and followed the patient's frame of reference. Towards the end of the first meeting the disclosure doctor asked a set of screening questions for depressive, anxiety, and somatoform disorders (DSM-IV). Between the two meetings, patients kept a diary for six days, in which they reported thoughts, emotions, physical sensations, and their activities at different moments each day. ${ }^{17}$ In the second meeting, the results of the patient's life story, the DSM-IV screening, and the diary were discussed, and patients were asked to write their own summary of the two meetings. Both the patient and the disclosure doctor rated the degree of disclosure. The three disclosure doctors in the trial (PJMP, AFS, PvdB) were general practitioners who had had a training session in the disclosure intervention.

\section{RANDOMISATION}

Eligible patients received information on the trial, and when they agreed to participate they were randomised. The randomisation was stratified (one stratum per practice), using a sequence of labeled cards in opaque, sealed, numbered envelopes. An independent person produced the randomisation envelopes, and the research assistant (MBFL), who did not apply the intervention, executed the randomisation procedure. Although the general practitioners knew which patients received the intervention, they were not told which patients participated as controls. The allocation scheme was broken after the two-year follow-up.

\section{OUTCOME MEASURES}

At baseline, six months, one year, and two years after entry in the trial, the patients completed a questionnaire on the outcome measures. Medical consumption over the previous six months was calculated on (a) the total number of visits to the general practitioner and other health care workers, and (b) the number of different medicines used daily for at least a week. Subjective health in the previous month ( 0 is very bad health, 100 excellent health) was the mean of seven visual analogue scales on the influence of symptoms on work, sleep, sport activities, social life, mood, ruminating about being ill, and health. Sick leave, the patient's inability to undertake his or her job or household chores, was expressed in number of weeks over the previous six months.

Of the additional measures, the severity of symptoms was assessed with the somatisation, depression, anxiety, and agoraphobia sub-scales of the SCL-90 (Symptom Check List ${ }^{18}$ ). Patients rated their quality of life on a visual analogue 
scale ( 0 is very low quality, 100 very high quality). The physician's diagnosis of somatisation of each patient was rated on a five-point Likert scale (1 is no somatisation, 5 severe somatisation), validated in another study. ${ }^{16}$ Social support ${ }^{19}$ was the average support received from the five most important persons in the patient's life ( 0 is no support, 100 very high support). The number of life events in the previous year, ${ }^{19}$ problems in childhood, ${ }^{7}$ chronic difficulties, ${ }^{19}$ and attitude towards illness were assessed as well, for comparison at baseline.

\section{STATISTICAL ANALYSIS}

The required sample size was estimated in order to detect a difference of at least 25\% (a worthwhile difference for a time-intensive treatment) between the intervention and control condition on the main outcome measure: medical consumption. With a two-sided significance level of $5 \%$, a power of $80 \%$, and taking into account a dropout rate of up to $25 \%$, the number of patients per group had to be 80 .

The analysis was based on intention to treat, and included all patients who completed baseline and 24-month follow-up questionnaires. Missing data in returned questionnaires were completed by telephone contact with the patient. The relative effectiveness of the intervention was determined by comparing the change in primary outcome variables between baseline and two years (HodgesLehman estimate of shift of the difference between intervention and control groups in change of outcome variables, based on a two sided Mann-Whitney $U$ test, with $95 \%$ confidence interval). Subgroup analyses were planned beforehand on: (a) high versus low DSM-III-R somatisation score, (b) high versus low somatisation according to the physician's judgement of somatisation, (c) presence or absence of major childhood problems, (d) presence or absence of depression and anxiety, (e) whether or not patients disclosed emotionally important information during the intervention, and $(f)$ whether or not patients participated in the joint consultation.

\section{RESULTS}

Figure 1 shows the progress of patients throughout the study. Of the 10,161 patients between 20 and 45 years of age in the ten practices, 1,064 patients $(10.5 \%)$ were frequent attenders without serious disease. The somatisation questionnaire was returned by 714 frequent attenders (67.1\%), of whom $362(50.7 \%)$ reported five or more somatisation symptoms. The non-responders to the questionnaire (32.9\%) were relatively often unmarried men, living alone, with psychological problems, particularly addiction to alcohol and hard drugs. Of the 362 patients eligible for the trial, 87 did not answer phone calls or letters, and 35 


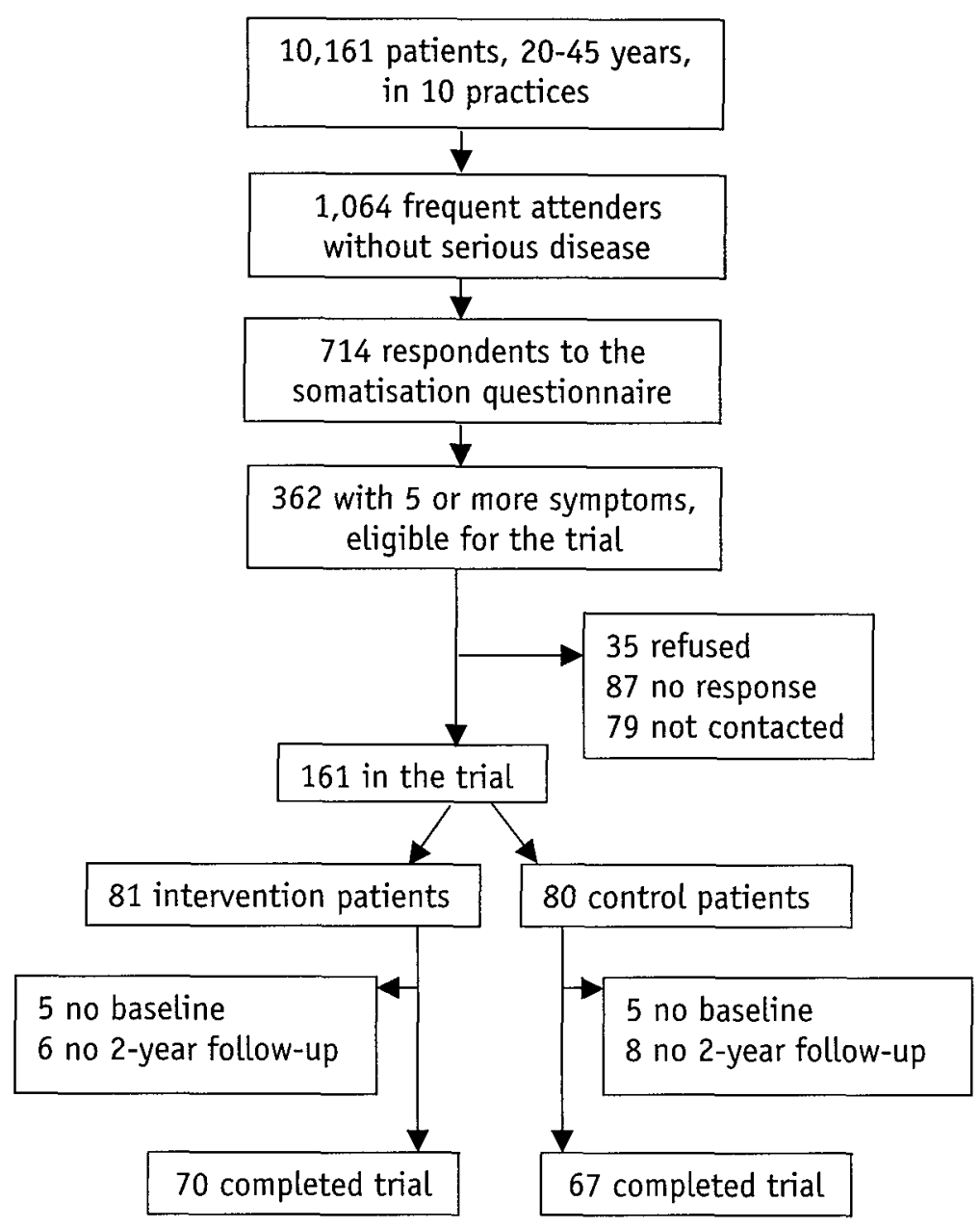

Figure 1: Trial profile

did not agree to participate. Seventy-nine patients were not contacted because enough patients had already been enrolled. Accordingly, 161 patients were included in the trial.

Altogether 137 patients completed the trial; 24 patients (14.9\%) dropped out and were not included in the final analyses. Ten patients ( 5 intervention, 5 control) did not return the baseline questionnaire, and 14 (6 intervention, 8 control) did not return the two-year follow-up. Of these 14, two control patients were admitted in a psychiatric clinic, two died ( 1 control, 1 intervention), three patients ( 1 intervention, 2 control) moved, with no forwarding address, and the 
remaining seven ( 4 intervention, 3 control) did not return the two-year questionnaire in spite of several reminders.

Of the 81 intervention patients, 77 actually received the disclosure intervention and completed the two meetings with the disclosure doctor; the remaining four dropped out before receiving the intervention. Twenty-two patients participated in an additional joint consultation with their own physician. Of the remaining 55 patients, 30 did not disclose important information in the two meetings, 9 had previously discussed the disclosed information with their physician, 11 patients did not want to share the disclosed topics with their physician, and 5 gave no clear reason why they did not participate in the joint consultation.

According to the opinion of the patients and disclosure doctors, 47 patients disclosed emotionally important information during the intervention. Topics of disclosure were childhood abuse (sexual, physical, or mental), alcohol dependency of parents, and loss of a parent or sibling at young age. Quite often patients reported they had had to bear onerous household responsibilities as young children. A range of problems in adulthood were disclosed: physical or sexual abuse, alcoholism, problems in relationships or at work, and social isolation. Commonly, disclosed problems were reported in combination, for example, sexual abuse in childhood and a depression in later life with problems in marriage. According to the DSM-IV screening, 34 of the 77 patients had an active depressive or anxiety disorder (16 a depressive disorder, 30 an anxiety disorder). Two patients fulfilled criteria of DSM-IV hypochondriasis and 18 of a DSM-IV chronic benign pain-syndrome.

At the start of the study, both groups were very similar on any of the demographic or clinical variables (table 1). Changes in main outcome measures during two years of follow-up were not significantly different between the two treatment conditions (table 2). Visits to health care increased more in the disclosure group at 24 months (difference $1, \mathrm{CI}:-4,6$ ); the use of medicines did not change in either group (CI: $-1,1)$; subjective health improved 3.6 points less in the disclosure group (CI: $-11.2,4.3$ ); and disclosure patients were on sick leave one more week (CI: $-1,3)$. Detailed analyses of visits to specific health care professionals and use of different kinds of medication did not yield relevant differences (table 3). In addition, changes in subsidiary outcome measures (quality of life, SCL-90, social support, and physician's judgement of somatisation) were also not different between the groups (table 2). The general picture was the same at 6 - and 12-month follow-up (data not presented). In the sub- group analyses, as mentioned in the methods section, no significant differences were found. Neither successful disclosure nor participation in the joint consultation made a difference.

In general, the disclosure intervention was well received: 57 out of 77 patients judged it as positive, and at two years of follow-up more intervention 
Table 1 Comparison of both treatment groups at baseline. $\mathrm{N}=151$

$\begin{array}{lll}\text { scale } & \text { Disclosure } & \text { Usual care } \\ \text { range } & \mathrm{N}=76 & \mathrm{~N}=75 \\ & \text { median or percentage } & \text { median or percentage } \\ & \text { (inter-quartile range) } & \text { (inter-quartile range) }\end{array}$

\section{Patient characteristics}

Age in years

Female sex

Married or cohabiting

Educational status: low middle high

Professional status: low middle high

Paying job

Immigrant status

Public insurance

$\begin{array}{cc}20-45 \quad 38(33-41) & 39(36-41) \\ 80 \% & 78 \% \\ 74 \% & 83 \% \\ 48 \% & 55 \% \\ 47 \% & 43 \% \\ 5 \% & 2 \% \\ 58 \% & 64 \% \\ 37 \% & 35 \% \\ 5 \% & 1 \% \\ 55 \% & 52 \% \\ 3 \% & 7 \% \\ 78 \% & 86 \%\end{array}$

\section{Outcome measures}

Medical consumption

- $\mathrm{N}$ of visits to all health care ${ }^{\mathrm{a}}$

$-N$ of different medicines ${ }^{a}$

$\begin{array}{lc}0- & 5(3-14) \\ 0- & 2(1-3) \\ 0-100 & 44(27-60) \\ 0-26 & 2(0-5)\end{array}$

$7(3-14)$

Subjective health (preceding month)

$0-26 \quad 2(0-5)$

$2(1-2)$

Sick leave in weeks ${ }^{a}$

$\begin{array}{lll}0-100 & 50(36-75) & 51(40-73) \\ 0-48 & 20(16-25) & 22(17-27) \\ 0-64 & 22(13-33) & 22(15-35) \\ 0-68 & 15(9-23) & 17(10-31) \\ 1-5 & 3.7(3.0-5.0) & 3.7(3.0-5.0) \\ 0-100 & 66(59-71) & 65(58-70)\end{array}$

\section{Subsidiary outcome measures}

Quality of life

Symptom Check List (last week)

- SCL somatisation scale

- SCL depression scale

- SCL anxiety + agoraphobia scale

Somatisation according to physician ${ }^{b}$

Social support

$47(33-63)$

$2(0-6)$

\section{Other measurements}

$\mathrm{N}$ of consultations to physician ( 3 yrs) Somatisation symptoms DSM-III-R $\mathrm{N}$ of life events (preceding year)

Chronic difficulties

$\mathrm{N}$ of childhood problems

$\begin{array}{lc}15-77 & 22(18-28) \\ 5-37 & 8(6-11) \\ 0-30 & 3(1-4) \\ 0-60 & 10(5-17) \\ 0-8 & 2(1-3) \\ 0-96 & 32(26-47) \\ 0-44 & 16(11-23) \\ & 6 \% \\ & 4 \% \\ & 45 \%\end{array}$

$20(17-28)$

$8(6-11)$

$2(1-3)$

$7(2-14)$

$2(0-3)$

$37(27-46)$

Illness attitude scale (IAS)

Health anxiety sub-scale in IAS

Depression in physician record

$17(12-25)$

Anxiety disorder in physician record

Chronic disease(s) in physician record ${ }^{c}$

$45 \%$

$5 \%$

$31 \%$

a. Preceding six months

b. Mean instead of median because of scalesize

c. A selection of 44 ICPC coded, prevalent chronic somatic disease conditions, e.g., diabetes mellitus, asthma, osteo-arthritis, or cardiovascular diseases 


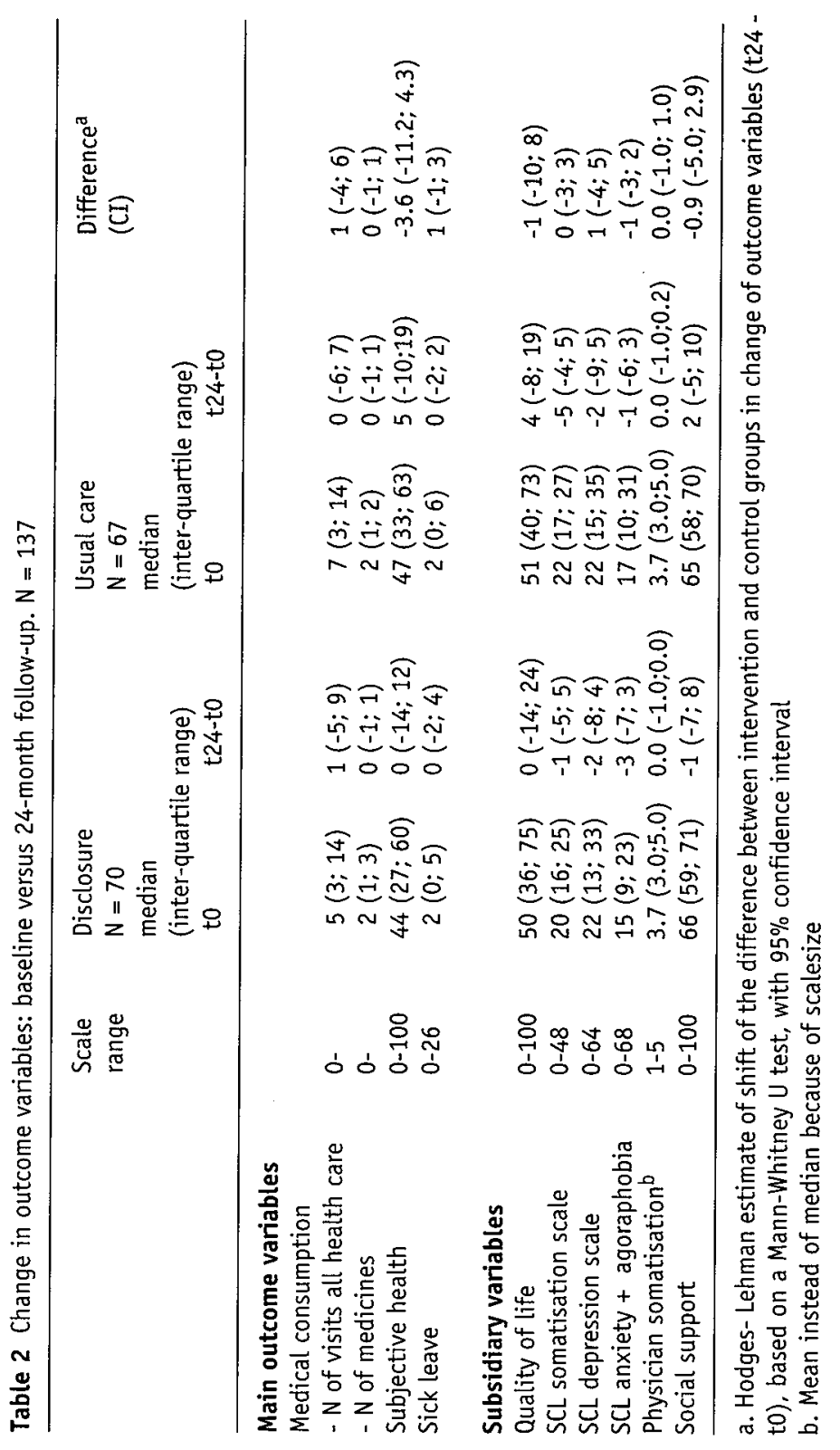


Table 3 Visits to health care and use of medication at baseline and two-year follow-up. $N=137$

\begin{tabular}{|c|c|c|c|c|c|}
\hline & \multicolumn{2}{|c|}{$\begin{array}{l}\text { Disclosure } \\
\mathrm{N}=70\end{array}$} & \multicolumn{2}{|c|}{$\begin{array}{l}\text { Usual care } \\
N=67\end{array}$} & \multirow[t]{2}{*}{$\begin{array}{l}O R^{a} \\
(C I)\end{array}$} \\
\hline & to & $\mathrm{t} 24$ & to & $\mathrm{t} 24$ & \\
\hline $\mathrm{N}$ of visits to physician (mean $)^{\mathrm{C}}$ & 2.9 & 2.4 & 3.4 & 3.0 & $0(-1 ; 1)^{b}$ \\
\hline \multicolumn{6}{|c|}{ Percentage of patients who visited $\mathrm{C}$} \\
\hline Specialists & $44 \%$ & $41 \%$ & $42 \%$ & $36 \%$ & $1.3(0.6 ; 2.7)$ \\
\hline Physiotherapists & $27 \%$ & $28 \%$ & $24 \%$ & $33 \%$ & $0.8(0.4 ; 1.7)$ \\
\hline Psychologists & $14 \%$ & $11 \%$ & $15 \%$ & $13 \%$ & $0.8(0.3 ; 2.4)$ \\
\hline Social workers & $11 \%$ & $7 \%$ & $3 \%$ & $5 \%$ & $1.1(0.2 ; 5.4)$ \\
\hline Complementary medicine & $16 \%$ & $9 \%$ & $7 \%$ & $10 \%$ & $0.5(0.1 ; 1.9)^{\wedge}$ \\
\hline Other health care & $6 \%$ & $9 \%$ & $5 \%$ & $9 \%$ & $0.9(0.3 ; 3.1)$ \\
\hline \multicolumn{6}{|l|}{ Percentage patients on ${ }^{d}$} \\
\hline Antidepressants & $11 \%$ & $11 \%$ & $12 \%$ & $16 \%$ & $0.6(02 ; 1.8)$ \\
\hline Sedatives & $11 \%$ & $16 \%$ & $10 \%$ & $12 \%$ & $1.4(0.5 ; 3.9)$ \\
\hline Pain killers & $51 \%$ & $59 \%$ & $45 \%$ & $43 \%$ & $1.8(09 ; 3.8)$ \\
\hline
\end{tabular}

a. Logistic regression model, $O R$ for intervention patients at $t 24$, controling for to

b. Hodges-Lehman estimate of shift of the difference between intervention and control groups in change of outcome variables ( $t 24-t 0$ ), based on a Mann-Whitney $U$ test, with $95 \%$ confidence interval

c. Over the preceding six months

d. Drugs used for at least a week daily, for the preceding six months

$\wedge .0 .05<p<0.10$

than control patients thought participation in the study changed their health favourably (not significant, $p=0.11$ ). However, this finding was not consistent with the 6- and 12-month outcome data, which showed no difference at all. A single patient criticised the disclosure intervention; she refused to be confronted with her childhood story again.

We did two checks for possible contamination between the two branches of the trial. General practitioners were asked to identify the control patients in their practice from a larger list of patients towards the end of the trial. Fourteen patients $(17 \%)$ were identified as such, 21 patients (26\%) were falsely identified as intervention patients, and 45 patients were guessed by the general practitioner to be non-participants in the trial (kappa 0.08). As a second check, we followed 98 patients in the additional nine practices where no intervention was introduced (data not presented). These 98 patients showed similar characteristics at baseline to the intervention and control patients, and changes on primary outcome measures at the two-year follow-up were not significantly different from the intervention and control group. The only difference was that patients in the intervention group, compared to patients in external practices, somatised less according to the physician's judgement at the two-year follow-up ( $\mathrm{p}=0.01)$. 


\section{DISCUSSION}

We did not find any effect of the disclosure intervention on medical consumption, subjective health, or sick leave, in somatising patients in general practice. No effect was found in those patients disclosing important information, nor in subgroups of patients with strong somatisation tendencies, depression, anxiety, or a traumatic childhood. The technique, duration, and frequency of our intervention were in accordance with the recommendations in a recent meta-analysis on emotional expression. ${ }^{10}$ This study shows that short writing tasks may significantly improve subjective health, but not so much health behaviours ${ }^{10}$ (like medical consumption); however, this last finding has been disputed. ${ }^{11}$ We did not find any effect of disclosure in somatising patients, although a positive effect of disclosure in somatisation cannot be completely ruled out, since the $95 \%$ confidance intervals were wide in our study. Emotional expression may not lead to similar positive health outcomes in long-term somatisers, when compared to student populations, or other groups of patients, such as holocaust survivors. ${ }^{10,12}$ Somatisers have an established pattern of medical consumption and may, therefore, not easily improve through a short disclosure intervention. Their symptoms may be quite independent of earlier life experiences. Possibly, a more sustained disclosure intervention, allowing patients to link symptoms to earlier traumatic events, and process this trauma, may yield better results. When we take into account the positive reactions of patients and their physicians in our trial, they seem to have profited from the disclosure intervention, but this did not result in a measurable improvement of outcome measures.

Although the trial was not blind, the general practitioners did not identify most of their control patients. We cannot rule out, however, that some control patients may have profited from their physician's participation in the trial, thereby masking an effect of the disclosure intervention. If such contamination existed, it must have been small, since patients in the extra control practices had, on average, comparable results on all main outcome measures to intervention and control patients.

Altogether, disclosure was not achieved in about $40 \%$ of the intervention patients. Patients may not have had anything to disclose or were not ready to share their experiences. Some patients had already shared the traumatic experiences with their physician, and an additional effect of the intervention may have been limited. All somatisers approached by us knew about the aim and method of the study through the informed-consent procedure, and patients not willing to share their traumatic experiences may have refused participation in the study. It remains unclear whether refusing patients could profit from a disclosure intervention, if offered at another moment or in a different way. 
We compared our findings with studies on other techniques in somatisation. Management strategies focussed on structuring general practitioner or specialist care through psychiatric consultations show positive ${ }^{20}$ as well as neutral ${ }^{21}$ results in somatisation. Strategies aimed at 'medical behaviour' and illness attributions of patients in primary and secondary care have been described as (partially) effective. ${ }^{22,23}$ It seems that strategies focussing on the other elements of Lipowski's definition of somatisation ${ }^{3}$ (see introduction), such as illness attributions and use of health care, may yield better results than disclosure of traumatic experiences. Personal interest of physicians in their patients' life stories remains crucial in communication, ${ }^{24-26}$ but will probably not in itself improve medical consumption, subjective health, or sick leave.

An alarming finding is the high prevalence of depressive and anxiety disorders in the (intervention) patients under study. The participating general practitioners had hardly registered these psychiatric disorders and few patients had received adequate treatment for these disorders. Instead, patients tended to visit specialists and physiotherapists and were taking painkillers. The patients under study did not improve, on average, in main outcome measures during the followup period of two years. Since no improvement was observed, and the group under study is both young and highly prevalent (5\%) in general practice, strategies in dealing with somatisation certainly deserve further scientific attention.

We conclude that, although valued by both general practitioners and their patients, disclosure of emotionally important events did not show an effect in somatising patients in general practice. Other strategies, such as cognitivebehaviouristic methods, may be more promising for somatisation in primary care. 


\section{REFERENCES}

1. Escobar JI, Burnam MA, Karno M, Forsythe A, J.M. G. Somatization in the community. Arch Gen Psychiatry 1987;44:713-718.

2. Portegijs PJM, van der Horst FG, Proot IM, Kraan HF, Gunther NC, Knottnerus JA. Somatization in frequent attenders of general practice. Soc Psychiatry Psychiatr Epidemiol 1996;31:29-37.

3. Lipowski ZJ. Somatization: The concept and its clinical application. AmJ Psychiatry 1988;145:1358-1368.

4. Goldberg D, Bridges K. Somatic presentations of psychiatric illness in primary care setting. J Psychosom Res 1988;32:137-144.

5. American Psychiatric Association. Diagnostic and statistical manual of mental disorders, $3^{\text {rd }}$ ed. revised. Washington DC: American Psychiatric Association, 1987: 261-264.

6. Arnold RP, Rogers D, Cook DA. Medical problems of adults who were sexually abused in childhood. BMJ 1990;300:705-708.

7. Portegijs PJM, Jeuken FM, van der Horst FG, Kraan HF, Knottnerus JA. A troubled youth: relations with somatization, depression and anxiety in adulthood. Fam Pract 1996;13:1-11.

8. Craig TK, Boardman AP, Mills K, Daly Jones O, Drake H. The South London Somatisation Study. I: Longitudinal course and the influence of early life experiences. Br J Psychiatry 1993;163:579-588.

9. George E. A cultural and historical perspective on confession. In: Pennebaker JW, ed. Emotions, disclosure, and health. Washington DC: The American Psychological Association, 1995: 11-22.

10. Smyth JM. Written emotional expression: effect sizes, outcome types, and moderating variables. J Cons Clin Psychol 1998;66:174-184.

11. Pennebaker JW. Writing about emotional experiences as a therapeutic process. Psychol Sci 1997;8:162-166.

12. PennebakerJW, Barger SD, Tiebout J. Disclosure of traumas and health among Holocaust survivors. Psychosom Med 1989;51:577-589.

13. Metsemakers JFM, Höppener P, Knottnerus JA, Kocken RJJ, Limonard CBG. Computerized health information in the Netherlands: a registration network of family practices. BrJ Gen Pract 1992;42:102-106.

14. de Bakker D, Kulu-Glasgow I, Abrahamse H, et al. Annual report LINH 1997 (in Dutch). Utrecht: NIVEL, 1998.

15. Escobar JI, Waitzkin H, Silver RC, Gara M, Holman A. Abridged somatization: a study in primary care. Psychosom Med 1998;60:466-472.

16. Schilte AF, Portegijs PJM, Blankenstein AH, Knottnerus JA. Somatisation in primary care: clinical judgement and standardised measurement compared. Soc Psychiatry Psychiatr Epidemiol 2000;35:276-282. 
17. de Vries MW, ed. The experience of psychopathology: investigating mental disorders in their natural settings. Cambridge UK: Cambridge University Press, 1992.

18. Derogatis L, Cleary P. Confirmation of the dimensional structure of the SCL-90: a study in construct validation. J Clin Psychol 1977;33:981-989.

19. Portegijs PJM. Somatization in frequent attenders of general practice. Ph.D. thesis: University of Maastricht, 1996.

20. Smith GR, Rost K, Kashner TM. A trial of the effect of a standardized psychiatric consultation on health outcomes and costs in somatizing patients. Arch Gen Psychiatry 1995;52:238-243.

21. Katon WJ, Von Korff M, Lin E, et al. A randomized trial of psychiatric consultation with distressed high utilizers. Gen Hosp Psychiatry 1992;14:86-98.

22. Speckens AE, van Hemert AM, Spinhoven P, Hawton KE, BolkJH, Rooijmans HG. Cognitive behavioural therapy for medically unexplained physical symptoms: a randomised controlled trial. BMJ 1995;311:1328-1332.

23. Morriss RK, Gask L, Ronalds C, Downes Grainger E, Thompson H, Goldberg D. Clinical and patient satisfaction outcomes of a new treatment for somatized mental disorder taught to general practitioners. Br J Gen Pract 1999;49:263-267.

24. Salmon P, Peters S, Stanley I. Patients' perception of medical explanations for somatisation disorders: qualitative analysis. BMJ 1999;318:372-376.

25. Cape J, McCulloch Y. Patients' reasons for not presenting emotional problems in general practice consultations. BrJ Gen Pract 1999;49:875-879.

26. Di Blasi Z, Harkness E, Ernst E, Georgiou A, Kleijnen J. Influence of context effects on health outcomes: a systematic review. Lancet 2001;357:757-762. 
Chapter 7

Predictors of prognosis in long-term somatisation in primary care, the role of stress

AF Schilte, AH Blankenstein, PJM Portegijs, HE van der Horst, JTM van Eijk, $M$ de Haan, and JA Knottnerus

To be submitted 


\section{ABSTRACT}

Background The natural course of somatisation and predictors of prognosis are important in the allocation of time-intensive management strategies for somatisation in general practice. We studied whether subjective health, sick leave, health care visits, and use of medicines were predicted by frequency of GP attendance in previous years and by stress factors, in somatising patients.

Methods 376 frequently attending somatisers, between 20 and 45 years of age, in 27 general practices, filled in questionnaires at baseline, and at one-, and two-year follow-up. Data were collected on the outcome measures (subjective health, sick leave, and medical consumption) and on GP attendance in the previous three years, problems in childhood, life events, chronic difficulties, and social support.

Results Overall, outcome measures were stable in the total group of somatising patients. Chronic difficulties and life events were strong cross-sectional indicators of outcome. Only social support had an independent long-term protective effect on outcome, increasing over time.

Conclusion We are far from being able to predict which patients, among those with a chronic tendency to somatisation, will become increasingly disabled or dependent on health care. When selecting somatising patients who need treatment most, GPs should focus on patients with impaired subjective health and high medical consumption, especially those who lack social support. 


\section{INTRODUCTION}

Somatisation is a highly prevalent problem in general practice with major consequences for patients' subjective health, disability, and medical consumption. ${ }^{1,2}$ Most general practitioners (GPs) consider somatising patients to be diffi$\mathrm{cult}^{3}$ or even frustrating, ${ }^{4}$ and the resulting rejecting attitude of GPs may give patients the feeling that the reality of their symptoms is being denied. ${ }^{5}$ Effective 'reattribution' treatment of somatisation in primary care has been described lately, with improvement in health and a considerable decrease in medical consumption. ${ }^{6,7}$ However, these treatments require thorough training of GPs and an extra initial time investment per somatising patient. Therefore, limiting the number of somatising patients to be treated per practice seems realistic. ${ }^{7}$ In order to provide treatment for the group of highest need, the natural course of somatisation and predictors of prognosis have to be known. Obviously, somatisers who are not doing well at present (low subjective health, high frequency of sick leave, frequent attendance, and high medical consumption) should receive priority of treatment. ${ }^{8,9}$ The question arises which additional factors can help the GP to predict who will deteriorate, and who will recover spontaneously. The level of stresses in the patient's life may influence which patients increasingly become disabled and dependent on health care. ${ }^{1,10,11}$ Life events, chronic difficulties, a problematic childhood, and poor social support have been identified as stress factors. ${ }^{12-15}$

The aims of this study are (a) to describe the clinical course of general practice patients, who have been somatising in previous years, in terms of subjective health, sick leave, visits to health care, and use of medicines, and (b) to identify stress factors that predict the prognosis over a two-year period.

\section{METHODS}

For this study, data from two studies with identical design and inclusion criteria, testing two interventions (reattribution and disclosure) for somatisation, were pooled. ${ }^{7}, 16$

\section{RECRUITMENT OF SOMATISING PATIENTS}

Frequently attending patients, between 20 and 45 years of age, received a postal questionnaire inquiring into any somatisation symptoms they had experienced during their life. Frequent attendance was defined as 15 contacts or more (on the patient's initiative) with their GP, in the previous three years. We estimated this would select the $10 \%$ most frequently attending patients for this age group in the Netherlands. ${ }^{17,18}$ The somatisation questionnaire was developed by 
the authors and validated in a pilot study, and contained the 37 somatisation symptoms, with the pertinent follow-up questions, listed in DSM-III-R (Diagnostic Statistical Manual of Psychiatric Disorders, $3^{\text {rd }}$ revised edition). ${ }^{19}$ Symptoms counted when not explained by use of medicines, alcohol, or drugs, and when not explained by organic disease (based on the examination of the GP or specialist, as reported by the patient in the questionnaire). Frequently attending patients reporting five or more somatisation symptoms in their lifetime (Somatic Symptom Index, SSI 5/5) were eligible for the study. 2,20,21

Patients with the following serious somatic or mental diseases were excluded: cancer, AIDS, rheumatoid arthritis, multiple sclerosis, dementia, schizophrenia, mental retardation, and psychosis. Patients with other chronic diseases, such as asthma, osteoarthritis, or cardiovascular diseases were not excluded to maintain a high generalisability for patients in primary care.

\section{OUTCOME MEASURES AND OTHER VARIABLES}

At baseline, at one, and at two years after entry in the study, patients completed questionnaires on outcome measures. Subjective health in the previous month ( 0 is very bad health, 100 is excellent health) was operationalised as the average of (a) a direct question on health (visual analogue scale), and (b) a combined score of six questions on the influence of symptoms on work, sleep, sport activities, social life, mood, and ruminating about being ill. Sick leave was expressed in weeks absent from work (or household activities) because of illness over the previous six months. Medical consumption over the previous six months was calculated as (a) the total number of visits to all health care workers, and (b) the number of different medicines used daily for at least a week.

Possible predictors of somatisation were measured at baseline. Social support was the average support of the five most important persons in the patient's life ( 0 is no support, 100 is very strong support). Chronic difficulties consisted of a list of 20 long-term problems in relations with relatives and friends, or situations such as work, housing, and financial affairs ( 0 is no problem, 3 severe problems). ${ }^{22}$ On a checklist of 29 events, patients reported the number of life events in the previous year. Childhood problems (until the age of 18) comprised a checklist of questions on lack of parental care (death, divorce, nervous breakdown of parent(s), living in an institution, foster home, or boarding school), too much responsibility as a child, and an open question on abuse or other severe events or circumstances in childhood. ${ }^{15,23}$ Abuse was defined as any serious, threatening, and unwanted sexual experience or beating. An occasional nonthreatening sexual experience with playmates, or non-threatening physical reprimand was not counted as abuse. ${ }^{24}$ Each childhood event could only count in one category, adding up to a total score between zero and eight. 


\section{STATISTICAL ANALYSIS}

Since the measures of outcome had skewed distributions, non-parametric tests were used throughout. To analyse the influence in time of possible predictors on outcome, bivariate analyses were performed with the four measures of outcome at the baseline, one-year, and two-year follow-ups. As a next step, the four measures of outcome were dichotomised at their median scores to allow logistic regression. Separate logistic regression models (LR-backward elimination) were used to analyse the influence of predictive factors at the two-year follow-up, after the baseline outcome and patient's trial-intervention status were forced into the models. Odds ratios were calculated (a) per point of scale of predictors and (b) from the 10th to the 90th percentiles of predictors, to allow direct comparison between predictors. In extra sets of analyses, patients receiving reattribution and disclosure interventions were removed from the analyses to assess whether this influenced the results.

\section{RESULTS}

A total of 376 somatising patients from 27 practices (12 in Amsterdam, 15 in Maastricht) participated in the study. After one reminder, 336 questionnaires were returned at one year and 339 at two years. The 14 patients not responding to both follow-up questionnaires were very similar to the respondents, except for a higher frequency of immigrants (36\% versus $11 \%$ ).

Patients from both locations were very similar in baseline characteristics (table 1). More Amsterdam than Maastricht patients were living alone, patients in Amsterdam had, on average, a slightly higher level of education and work, and more often had an immigrant background. Patients in Amsterdam reported slightly lower subjective health, had made more visits to health care professionals, and reported more weeks of sick leave over the previous six months.

Patients reported, on average, a rather low subjective health of 42 (range $0-100$ ), were absent from their work for three weeks, had visited a health care professional eight times, and had taken two different medicines, in the previous six months. The outcome variables remained stable over the follow-up period of two years (table 2). Individual patients, however, varied considerably in subjective health, sick leave, health care visits, and use of medication over the two years.

Chronic difficulties and, to a lesser extent, GP consultations in the previous three years correlated strongly with the different measures of outcome at baseline, but gradually lost predictive power during the two years follow-up (table 3). Life events in the previous year correlated with baseline outcome data, but rapidly lost predictive power at one and two years. Social support hardly correlated with baseline outcome, but gained predictive power for subjective 
Table 1 Baseline characteristics

\begin{tabular}{|c|c|c|c|c|}
\hline & scale & $\begin{array}{l}\text { Amsterdam } \\
\mathrm{N}=172 \\
\text { median }^{\mathrm{a}}\end{array}$ & $\begin{array}{l}\text { Maastricht } \\
\mathrm{N}=203 \\
\text { median }^{\mathrm{a}}\end{array}$ & $\begin{array}{l}\text { All patients } \\
\mathrm{N}=376 \\
\text { median }^{\mathrm{a}}\end{array}$ \\
\hline \multicolumn{5}{|l|}{ Sociodemographic characteristics } \\
\hline Age in years & $20-45$ & 36 & 37 & 37 \\
\hline Female sex ${ }^{a}$ & & $85.0 \%$ & $82.0 \%$ & $83.5 \%$ \\
\hline Married or cohabiting ${ }^{a}$ & & $82.7 \%$ & $96.1 \%$ & $89.9 \%$ \\
\hline Educational status: Low & & $39.0 \%$ & $50.5 \%$ & $45.1 \%$ \\
\hline middle & & $44.2 \%$ & $45.5 \%$ & $44.9 \%$ \\
\hline high & & $16.9 \%$ & $4.0 \%$ & $10.0 \%$ \\
\hline Professional status: low & & $66.1 \%$ & $62.4 \%$ & $64.1 \%$ \\
\hline middle & & $23.2 \%$ & $34.0 \%$ & $29.0 \%$ \\
\hline high & & $10.7 \%$ & $3.6 \%$ & $6.8 \%$ \\
\hline Immigrant status ${ }^{\mathrm{a}}$ & & $17.9 \%$ & $5.4 \%$ & $11.2 \%$ \\
\hline Paying job ${ }^{\mathrm{a}}$ & & $56.1 \%$ & $53.7 \%$ & $54.8 \%$ \\
\hline \multicolumn{5}{|l|}{ Outcome measures } \\
\hline \multicolumn{5}{|l|}{ Medical consumption } \\
\hline - $N$ of visits to all health care ${ }^{b}$ & $0-83$ & 10 & 7 & 8 \\
\hline - $N$ of different medicines ${ }^{b}$ & $0-9$ & 2 & 2 & 2 \\
\hline Subjective health previous month & $0-100$ & 39 & 45 & 42 \\
\hline Sick leave in weeks ${ }^{b}$ & $0-26$ & 4 & 2 & 3 \\
\hline \multicolumn{5}{|l|}{ Other measurements } \\
\hline GP consultations previous 3 years & $15-77$ & 19 & 21 & 20 \\
\hline DSM somatisation & $5-37$ & 7 & 8 & 7 \\
\hline Social support & $0-100$ & 43 & 40 & 42 \\
\hline Life events & $0-29$ & 2 & 2 & 2 \\
\hline Chronic difficulties & $0-60$ & 6 & 7 & 7 \\
\hline $\mathrm{N}$ of childhood problems & $0-8$ & 2 & 2 & 2 \\
\hline
\end{tabular}

a. Median for continuous variables, percentage for nominal variables

b. Preceding six months

Table 2 Main outcome measures at different moments of follow-up. $N=376$

\begin{tabular}{llllll}
\hline & range & $\begin{array}{l}\text { t0 } \\
\left.\text { median (iqr }{ }^{\mathrm{a}}\right)\end{array}$ & $\begin{array}{l}\mathrm{t12} \\
\text { median (iqr }{ }^{\mathrm{a}} \text { ) }\end{array}$ & $\begin{array}{l}\text { t24 } \\
\text { median (iqr }{ }^{\mathrm{a}} \text { ) }\end{array}$ & $\begin{array}{l}\text { t24-t0 } \\
\text { median (iqr }^{\mathrm{a}} \text { ) }\end{array}$ \\
\hline $\begin{array}{l}\text { Subjective health } \\
\text { Sick leave }\end{array}$ & $0-100$ & $42(27 ; 60)$ & $45(31 ; 64)$ & $50(30 ; 71)$ & $+5(-11 ;+20)$ \\
N of visits all health care & $0-83$ & $8(3 ; 20)$ & $8(3 ; 15)$ & $8(3 ; 18)$ & $-1(-9 ;+8)$ \\
N of different medicines & $0-9$ & $2(1 ; 3)$ & $2(1 ; 3)$ & $2(1 ; 3)$ & $0(-1 ;+1)$ \\
\hline
\end{tabular}

a. Inter-quartile range 
Table 3 Bivariate analyses (Spearman's rank correlation) between predictors of outcome and baseline, one-, and two-year follow-up data. $\mathrm{N}=376$

\begin{tabular}{|c|c|c|c|c|c|}
\hline & $\begin{array}{l}\text { GP cons. } \\
3 \text { years }\end{array}$ & $\begin{array}{l}\text { Social } \\
\text { support }\end{array}$ & Life events & $\begin{array}{l}\text { Chronic } \\
\text { difficulties }\end{array}$ & $\begin{array}{l}\text { Childhood } \\
\text { problems }\end{array}$ \\
\hline \multicolumn{6}{|l|}{ Baseline } \\
\hline Subjective health & $-0.17^{* *}$ & $0.13^{*}$ & $-0.17^{* *}$ & $-0.42^{\star * *}$ & -0.10 \\
\hline Sick leave & $0.12^{*}$ & 0.03 & $0.19^{* \star}$ & $0.13^{*}$ & 0.10 \\
\hline $\mathrm{N}$ of health care visits & $0.18^{* * *}$ & 0.04 & $0.12^{*}$ & $0.24^{* * *}$ & $0.11^{*}$ \\
\hline $\mathrm{N}$ of medicines & 0.09 & 0.01 & 0.08 & $0.23^{* * *}$ & $0.15^{\star \star}$ \\
\hline \multicolumn{6}{|l|}{ One-year follow-up } \\
\hline Subjective health & -0.09 & $0.18^{* \star}$ & -0.08 & $-0.18^{\star \star}$ & 0.02 \\
\hline Sick leave & 0.06 & -0.06 & $0.16^{\star \star}$ & $0.15^{*}$ & $0.11^{*}$ \\
\hline $\mathrm{N}$ of health care visits & $0.18^{\star *}$ & $-0.12^{\star}$ & 0.04 & $0.12^{\star}$ & $0.11^{*}$ \\
\hline$N$ of medicines & $0.11^{*}$ & -0.08 & 0.07 & $0.19 * *$ & 0.08 \\
\hline \multicolumn{6}{|l|}{ Two-year follow-up } \\
\hline Subjective health & -0.07 & $0.16^{\star *}$ & -0.02 & -0.12 & 0.01 \\
\hline Sick leave & $0.12^{*}$ & 0.04 & 0.10 & 0.01 & 0.04 \\
\hline $\mathrm{N}$ of health care visits & 0.10 & $-0.20 * * *$ & 0.01 & $0.14^{*}$ & $0.11^{\star}$ \\
\hline $\mathrm{N}$ of medicines & $0.14^{*}$ & 0.00 & 0.05 & 0.06 & 0.08 \\
\hline
\end{tabular}

${ }^{*}: \mathrm{p}<0.05 ;{ }^{* *}: \mathrm{p}<0.01 ;{ }^{* * *}: \mathrm{p}<0.0$

health and number of health care visits during the follow-up period. A problematic childhood was a weak predictor at baseline and at follow-ups.

In the regression analyses, the best independent predictors of outcome at the two-year follow-up were the baseline subjective health and medical consumption (table 4). Additionally, higher social support was associated with better subjective health and low numbers of health care visits. Strong social support seemed to be associated with more sick leave (in women), however this finding was not consistent with the bivariate analysis. Life events showed a trend towards predicting health care visits at the two-year follow-up. The total explained variance of the different predictive models remained very modest. At one year (data not presented) social support predicted subjective health and health care visits, problems in childhood predicted sick leave, and GP consultations in the previous three years predicted health care visits, with a total explained variance in the same range as the two-year data. Removal of the reattribution intervention group did not change the results. After removal of the disclosure group, social support no longer predicted sick leave. 


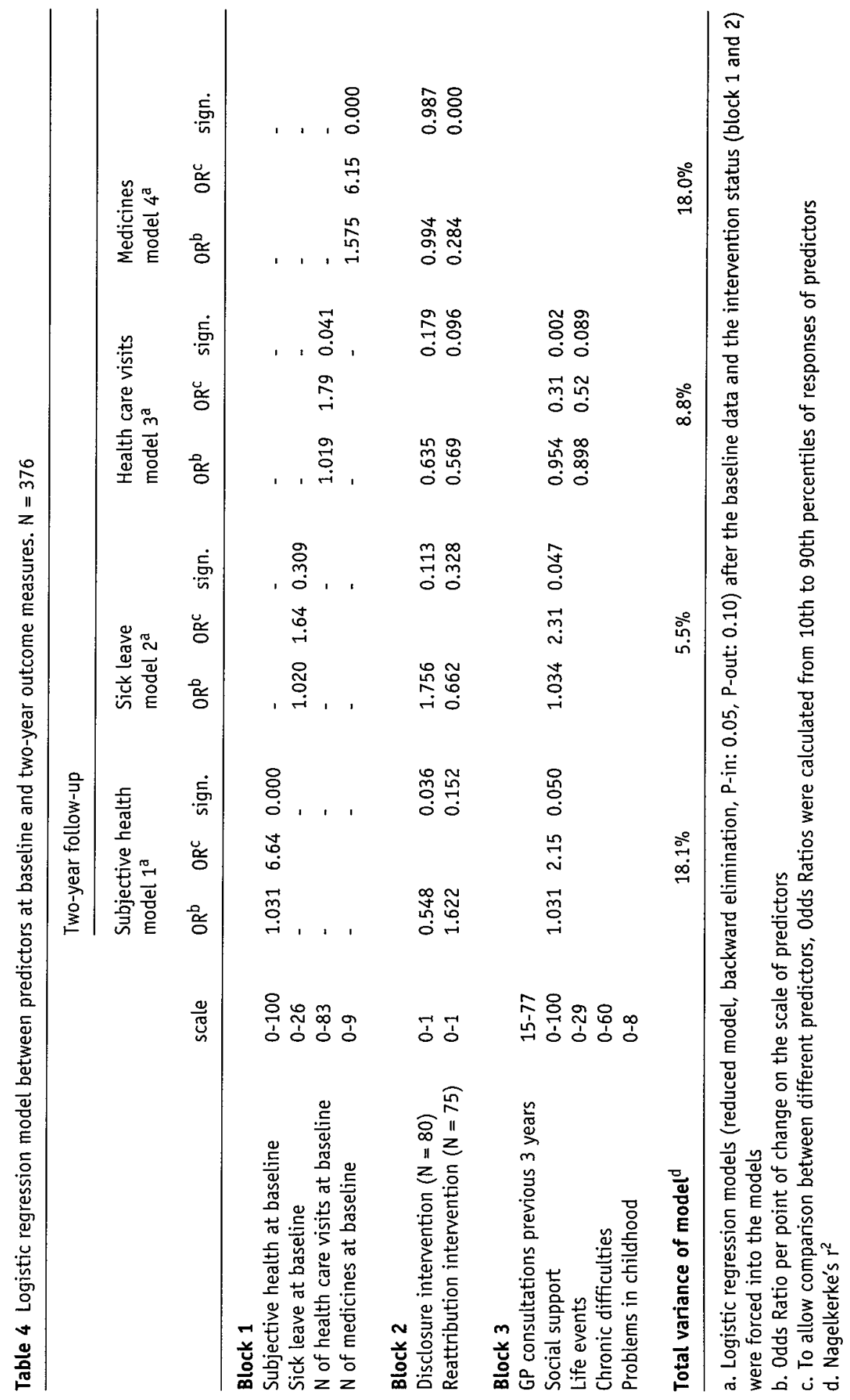




\section{DISCUSSION}

Somatising patients in this study are best described as patients with relatively poor sense of well-being, high medical consumption, and frequent sick leave, especially during stressful periods. Although individual patients varied considerably over time, a finding in line with earlier studies on somatisation in general practice, ${ }^{25}$ overall outcome measures were stable in the total group of patients over two years. This finding is not surprising, since we did not specifically select patients with somatisation complaints at the start of the study. Our focus was on patients with a prior tendency to develop somatisation symptoms.

The stressors chronic difficulties and life events showed strong cross-sectional correlations with clinical condition in our group, but lost most of their predictive power at the one- and two-year follow-ups. Our interpretation was that patients recovered from (or adjusted to) the stressful situation and their somatisation symptoms subsided. Childhood problems did not predict unfavourable outcome. A number of studies have shown a greater influence of childhood experiences on somatisation; however, these were all studies comparing somatisers with non-somatisers, ${ }^{13,15,26,27}$ whereas we studied clinical course within a group of somatising patients. Only social support had an independent long-term effect on outcome, increasing over time, which strongly suggested low social support to be a risk factor for deterioration in somatisers. Other authors have found similar results, both in the general population and, more specifically, in somatisating patients. ${ }^{28,29}$ Nevertheless, we are far from being able to predict which somatising patients will progressively become disabled or dependent on health care.

Subjective health and use of medicines at baseline were the best predictors of outcome in our study. For daily practice this implies that patients with poor subjective health and high use of medication are the ones at risk of later deterioration, especially when they have weak social support. In these patients active intervention may be indicated. Patients known as somatisers, who are doing relatively well at the moment, are preferably not selected for interventions.

\section{METHODOLOGICAL CONSIDERATIONS}

A limitation of this study was that we used data sets of two intervention studies, one of which proved to be effective. ${ }^{7}$ We made the choice to include intervention patients as well, and entered the intervention status as a modifier early in the regression analysis. The power of this study was too small to enter the interaction variables of intervention status and other predictors. Either of the two interventions may have influenced our results slightly. 


\section{CONCLUSIONS AND RECOMMENDATIONS}

We could not confirm that stresses make long-term somatising patients more prone to deterioration of their clinical condition over time, except for low social support. GPs who want to select long-term somatisers needing active intervention should focus on patients with a poor sense of well-being and high medical consumption, especially those who lack social support. 


\section{REFERENCES}

1. Lipowski ZJ. Somatization: The concept and its clinical application. Am J Psychiatry 1988;145:1358-1368.

2. Escobar JI, Rubio-Stipec M, Canino G, Karno M. Somatic symptom index (SSI): a new and abridged somatization construct. Prevalence and epidemiological correlates in two large community samples. J Nern Ment Dis 1989;177:140-146.

3. Schilte AF, Portegijs PJM, Blankenstein AH, Knottnerus JA. Somatisation in primary care: clinical judgement and standardised measurement compared. Soc Psychiatry Psychiatr Epidemiol 2000;35:276-282.

4. Lin EHB, Katon W, Von Korff M, et al. Frustrating patients: physician and patient perspectives among distressed high users of medical services. J Gen Int Med 1991;6: 241-246.

5. Salmon P, Peters S, Stanley I. Patients' perception of medical explanations for somatisation disorders: qualitative analysis. BMJ 1999;318:372-376.

6. Morriss RK, Gask L, Ronalds C, Downes Grainger E, Thompson H, Goldberg D. Clinical and patient satisfaction outcomes of a new treatment for somatized mental disorder taught to general practitioners. Br J Gen Pract 1999;49:263-267.

7. Blankenstein $\mathrm{AH}$, van der Horst HE, Schilte AF, et al. Effectiveness of reattribution for somatisation in general practice; a randomised controlled trial. submitted.

8. Hiller W, Rief W, Fichter MM. How disabled are patients with somatoform disorders? Gen Hosp Psychiatry 1997;19:432-438.

9. Speckens AE, van Hemert AM, Bolk JH, Rooijmans HG, Hengeveld MW. Unexplained physical symptoms: outcome, utilization of medical care and associated factors. Psychol Med 1996;26:745-752.

10. Fink P. Somatization-beyond symptom count. J Psychosom Res 1996;40:7-10.

11. Rief W, Hiller W. Toward empirically based criteria for the classification of somatoform disorders. J Psychosom Res 1999;46:507-18.

12. Brown GW, Harris TO. Social origins of depression: A study of psychiatric disorder in women. London: Tavistock Publications, 1978.

13. Craig TK, Boardman AP, Mills K, Daly Jones O, Drake H. The South London Somatisation Study. I: Longitudinal course and the influence of early life experiences. Br J Psychiatry 1993;163:579-588.

14. Craig TK, Drake H, Mills K, Boardman AP. The South London Somatisation Study. II. Influence of stressful life events, and secondary gain. Br J Psychiatry 1994;165: 248-258.

15. Portegijs PJM, Jeuken FM, van der Horst FG, Kraan HF, Knottnerus JA. A troubled youth: relations with somatization, depression and anxiety in adulthood. Fam Pract 1996;13:1-11.

16. Schilte AF, Portegijs PJM, Blankenstein AH, et al. Is disclosure of emotionally important events effective in somatisation in primary care? A randomised controlled trial. BMJ 2001: accepted. 
17. de Bakker D, Kulu-Glasgow I, Abrahamse H, et al. Annual report LINH 1997 (in Dutch). Utrecht: NIVEL, 1998.

18. Schilte AF, van den Akker M, Vlek H. Workload determinants for general practitioners. submitted 2001.

19. American Psychiatric Association. Diagnostic and statistical manual of mental disorders, $3^{\text {rd }}$ ed. revised. Washington DC: American Psychiatric Association, 1987: 261-264.

20. Escobar JI, Waitzkin H, Silver RC, Gara M, Holman A. Abridged somatization: a study in primary care. Psychosom Med 1998;60:466-472.

21. Portegijs PJM, van der Horst FG, Proot IM, Kraan HF, Gunther NC, Knottnerus JA. Somatization in frequent attenders of general practice. Soc Psychiatry Psychiatr Epidemiol 1996;31:29-37.

22. Hendriks A, Ormel J, Willige G. Long-term difficulties measured with self-report questionnaire and semi-structured interview (in Dutch). Gedrag en Gezondheid 1990;18:273-283.

23. Schilte AF, Portegijs PJM, Blankenstein AH, Latour MBF, van Eijk JTM, Knottnerus JA. Indicators of childhood adversity in somatisation in general practice. Scand J Prim Health Care 2001: accepted.

24. Draijer N. Sexual abuse of girls by relatives: A national study of prevalence, nature, family backgrounds, emotional significance and psychic and psychosomatic consequences (in Dutch). The Hague: Ministerie van Sociale Zaken en Werkgelegenheid, 1988.

25. Gureje O, Simon GE. The natural history of somatization in primary care. Psychol Med 1999;29:669-676.

26. Pribor EF, Dinwiddie SH. Psychiatric correlates of incest in childhood. Am J Psychiatry 1992;149:52-56.

27. Hotopf M, Wilson Jones C, Mayou R, Wadsworth M, Wessely S. Childhood predictors of adult medically unexplained hospitalisations. Results from a national birth cohort study. Br J Psychiatry 2000;176:273-80.

28. Cobb S. Social support as a moderator of life stress. Psychosom Med 1976;38:300-314.

29. Kouzis AC, Eaton WW. Absence of social networks, social support and health services utilization. Psychol Med 1998;28:1301-1310. 
Chapter 8

General discussion 


\section{MAIN FINDINGS}

We studied the effectiveness of a disclosure intervention on subjective health, sick leave, and medical consumption in patients with somatisation in general practice. We also investigated determinants of patient consultation rates, the general practitioner's (GP) clinical judgement of somatisation, the role of childhood trauma, and the predictive value of stress factors in patients with somatisation.

The disclosure intervention, applied by an independent GP, did not show an effect on medical consumption, subjective health, and sick leave in general practice somatisers, although a positive effect of disclosure was not completely ruled out (chapter 5 and 6 ).

One-third of the variance in attendance rates of patients to their GPs is explained by the disease and consultation pattern variables in previous years. Differences between practices contribute only marginally (chapter 2 ). The distribution of the GP's workload is very similar to distributions reported in other countries with different health care systems.

Patient attendance rates and communication problems between the GP and patient strongly influence GPs' judgement of somatisation. In their judgement of somatisation, GPs avoid contamination with other psychological problems like depression and anxiety disorders. The standardised measurement of somatisation (DSM-III-R) is valid as a research instrument, selecting patients with a history of unexplained physical symptoms, including symptoms related to depression and anxiety disorders. However, for research addressing somatisation as a practical clinical problem, the operationalisation of somatisation should include the clinical judgement of the practitioner as well.

Four out of five somatisers in general practice report at least one major problem in their childhood (chapter 4). Childhood adversity is independently associated with long-term difficulties, especially in relations, and with unexplained genital-sexual symptoms. Neither subjective nor objective health indicated childhood problems within our study population, selected on healthrelated variables. When GPs want to apply a more active approach towards somatisers, ${ }^{1}$ they can facilitate disclosure of childhood trauma when patients are known to have long-term difficulties in relations and genital-sexual symptoms.

Primary care patients with a tendency to present unexplained symptoms are best described as patients with a relatively poor sense of well-being, high medical consumption, and high disability, especially in times of stressful circumstances (chapter 7). The two stressors chronic difficulties and life events were strong cross-sectional indicators of somatisation, but their predictive power for outcome after one and two years of follow-up was limited. Only social support 
had an independent long-term effect on outcome, increasing over time, which suggested weak social support to be a risk factor for deterioration.

\section{METHODOLOGICAL CONSIDERATIONS}

In the literature different criteria have been used for selection of somatising patients. Counting symptoms over a relatively short period may cause a substantial 'regression to the mean' improvement at follow-up moments. Other authors on somatisation selected patients who presented somatisation symptoms, irrespective of whether the patient's history revealed a recurring tendency of somatisation. ${ }^{2,3}$ The patients in our study were general practice frequent attenders, with a history of unexplained symptoms, but not necessarily bothered by somatisation symptoms at the moment of entry in the study. We selected patients with a somatisation tendency and studied whether the disclosure intervention would prevent patients getting caught up in chronic unexplained complaints and medical consumption.

The question remains whether our study failed to prove an effect of disclosure in patients with somatisation due to methodological imperfections. The intervention study (chapter 6) is the first randomised controlled trial reporting on the effect of disclosure of emotionally important events in somatisation in general practice. Research on the effect of psychological interventions is often characterised by methodological problems. Obviously, a double-blind design is impossible in studying the effect of disclosure. Contamination between the two branches of the trial seems unlikely, since the intervention was carried out by an independent doctor and GPs usually did not recognise control patients. The follow-up period of two years in the trial is long enough to evaluate whether an effect lasted long enough to justify a time-intensive strategy for somatisation. A short-lived effect (shorter than six months) may have remained unnoticed in our study, but would not justify implementation in practice. Whether a more sustained disclosure intervention may enable patients to make the link between emotional experiences and their symptoms, remains to be studied.

Our selection procedure resulted in a relatively large percentage of women participating in the study (79\%). We chose equal selection criteria for men and women: 15 or more consultations in three years and the SSI $5 / 5$ (Somatic Symptom Index of 5 symptoms for men and 5 for women ${ }^{4}$ ), instead of the unbalanced SSI $4 / 6$ used by other authors. ${ }^{5}$ The difference in response rates between the sexes (men had a lower response rate to both the questionnaires and the informed consent procedure) contributed only marginally to this imbalance. Since the primary aim of this study was to investigate a means of dealing with somatisation in general practice consultation hours, we selected patients accord- 
ing to this criterion and did not stratify by gender. Women visit their GP more frequently and present somatisation symptoms more often and in a different way from men. ${ }^{6}$ We did not find that men and women responded differently to the disclosure intervention.

We were not able to look at the role of depression or anxiety disorders as modifying factors, which is mentioned by some authors as an important factor influencing the course of somatisation. ${ }^{7}$ To establish accurate psychiatric diagnoses among the whole study population would have required psychiatric face-to-face interviews in both the intervention and control groups, a method not in line with our trial protocol, which left control patients undisturbed as much as possible. It would have been unethical not to treat newly discovered psychiatric disorders in control patients. On one hand, patients with psychiatric co-morbidity may have profited more from the intervention; on the other, psychiatric co-morbidity may have complicated the treatment of somatisation. In the intervention group, patients with already established active depression or anxiety disorder according to DSM-IV had lower subjective health at baseline, but depression and anxiety disorders did not predict outcome at follow-up moments. Other authors also found persistence of symptoms not to be related to psychiatric disorders. ${ }^{8}$

\section{IMPLICATIONS OF THE STUDY}

Our hypothesis of the effectiveness of disclosure in somatisation was not confirmed (chapter 6). Even when we looked selectively at the patients who disclosed important information and shared it with their GP in the additional joint consultation, no effect was observed. This raises the question of whether talking about emotionally important events, often applied by GPs, has any positive effect at all in somatisation.

The patients in the trial reported that they appreciated the interest in their life and childhood story, and only one criticised the disclosure intervention as too confronting. About $60 \%$ of the patients in the trial disclosed emotionally important events, and half of these also wanted to discuss their story with their GP. Although a positive effect of disclure cannot completely be ruled out, we conclude, from the trial in this thesis, that disclosure by an independent GP did not show an effect on 'hard', measurable outcome measures, such as medical consumption, subjective health, and sick leave. We cannot say much about a disclosure intervention applied by the patient's own GP, or a more sustained intervention. Moreover, it may be impossible to isolate and study the contribution of the disclosure aspect in the ongoing relationships between patients and their GPs, since varying degrees of disclosure between patients and their GPs 
must have happened earlier. In addition, we cannot exclude the possibility that effects did occur on less measurable, more qualitative aspects. From my personal on-going experience as a full-time GP in daily practice, I value the merits of consultations in which patients disclose their life and childhood memories. I generally see positive effects when patients confide emotionally important events to me. Disclosure happens especially when patients trust me as their GP, as many patients apparently take psychosocial aspects into consideration as part of their problem. This results in a much broader ground for explanation of physical and mental complaints. When, on the other hand, patients are only open to somatic explanations of their complaints and have an external locus of control, ${ }^{9}$ and GPs do not show interest in their life story, this often results in poor communication. ${ }^{10}$ Patients develop higher attendance rates (chapter 2) and longer lists of health problems. ${ }^{9}$ In such situations, as a GP, I feel incompetent to help and I have observed tendencies of impatience, irritation, and not taking the patient's visit seriously. ${ }^{11}$ This easily results in the patient not feeling understood or, in other words, feeling as though the doctor denies the presence of their symptoms. ${ }^{12}$ In such situations, communication between doctor and patient gets bogged down between the patient's repetitive call for attention for somatic complaints and the GP's inadequate ways of dealing with these questions. Examples of this are not carrying out a proper examination, ordering diagnostic tests without reason to do so, quickly prescribing symptomatic therapies, and inadequately referring the patient. ${ }^{13}$ This uncomfortable and undesirable pattern may change when the somatising patient presents an acute somatic problem which necessitates immediate treatment (for example an acute appendicitis). If the GP does not correctly diagnose the severity of the problem, because of frustration with the patient's somatisation tendency, permanent disruption between patient and GP may result, and the patient may leave the practice. A correctly diagnosed somatic disease in a somatising patient may, on the other hand, change the communication too. The patient feels that the importance of the problem is acknowledged and the GP feels competent and approached for a problem within his or her expertise. Similarly, a correctly diagnosed and successfully treated depression, or the disclosure of an important life event may also improve the communication and common ground between patient and doctor. Warm, friendly, and reassuring manners of GPs have been acknowledged as having an important therapeutic effect in such situations. ${ }^{10}$ Where there is a broader common ground, GPs often have more patience and ability to interpret the patient's complaints. When the patient feels understood and the GP feels competent, it is a lot easier to plan a meaningful diagnostic and therapeutic strategy. The observation that GPs consider somatising patients to be difficult, tiresome, and frustrating (chapter 3) may change when GPs and patients find more common ground through talking about emotionally important events in the patient's life 
(chapter 4). I still consider talking about a patient's life story an indispensable aspect of good clinical practice, although it may, of itself, not be sufficient to change hard outcome variables, such as subjective health, medical consumption, and sick leave in somatisers. In view of our findings, recently developed cognitive-behaviouristic techniques to be applied by GPs, such as the reattribution method, ${ }^{3,14}$ may be promising additions in general practice in influencing subjective health, medical consumption, and sick leave in somatisation, especially when combined with an empathic, reassuring consultation style. ${ }^{10}$

\section{CONCLUSIONS AND RECOMMENDATIONS}

We conclude that an intervention strategy, applied by an independent GP and aimed at disclosure of emotionally important memories of patients, did not show an effect in somatisation on the outcome measures: subjective health, medical consumption, and sick leave. We do not conclude, however, that it is valueless; talking about the patient's life story may increase the ground of understanding between patients and their GPs, and may facilitate their communication.

We recommend further development and critical appraisal of other techniques applied by GPs, such as the reattribution intervention, for somatisation in general practice. We also recommend the use of disclosure of the patient's life story in cases of inadequate communication pattern between patients and their GPs. Further qualitative studies and effectiveness studies on the role of disclosure in specific target groups of somatising patients should be initiated. 


\section{REFERENCES}

1. van den Akker M, Mol S, MetsemakersJFM, Dinant GJ, Knottnerus JA. Barriers in the care of patients who have experienced a traumatic event: the perspective of general practice. Fam Pract 2001;18:214-216.

2. Speckens AE, van Hemert AM, Spinhoven P, Hawton KE, BolkJH, Rooijmans HG. Cognitive behavioural therapy for medically unexplained physical symptoms: a randomised controlled trial. BMJ 1995;311:1328-1332.

3. Morriss RK, Gask L, Ronalds C, Downes Grainger E, Thompson H, Goldberg D. Clinical and patient satisfaction outcomes of a new treatment for somatized mental disorder taught to general practitioners. Br J Gen Pract 1999;49:263-267.

4. Portegijs PJM. Somatization in frequent attenders of general practice. $\mathrm{Ph} . \mathrm{D}$. thesis: University of Maastricht, 1996.

5. Escobar JI, Rubio-Stipec M, Canino G, Karno M. Somatic symptom index (SSI): a new and abridged somatization construct. Prevalence and epidemiological correlates in two large community samples. J Nerv Ment Dis 1989;177:140-146.

6. van der Horst HE, van Dulmen AM, Schellevis FG, van Eijk JTM, Fennis JF, Bleijenberg $G$. Do patients with irritable bowel syndrome in primary care really differ from outpatients with irritable bowel syndrome? Gut 1997;41:669-674.

7. Rief W, Hiller W, Geissner E, Fichter MM. A two-year follow-up study of patients with somatoform disorders. Psychosomatics 1995;36:376-386.

8. Speckens AE, van Hemert AM, Bolk JH, Rooijmans HG, Hengeveld MW. Unexplained physical symptoms: outcome, utilization of medical care and associated factors. Psychol Med 1996;26:745-752.

9. van den Akker M. Multimorbidity in a general practice population, prevalence, incidence and determinants of multiple pathology. Ph.D. thesis: University of Maastricht, 1999.

10. Di Blasi Z, Harkness E, Ernst E, Georgiou A, Kleijnen J. Influence of context effects on health outcomes: a systematic review. Lancet 2001;357:757-762.

11. Mayou R, Sharpe M. Patients whom doctors find difficult to help. An inportant and neglected problem. Psychosomatics 1995;36:323-325.

12. Salmon P, Peters S, Stanley I. Patients' perception of medical explanations for somatisation disorders: qualitative analysis. BMJ 1999;318:372-376.

13. GrolR. Huisarts en somatische fixatie. Utrecht: Bohn, Scheltema \& Holkema, 1983.

14. Blankenstein $\mathrm{AH}$, van der Horst $\mathrm{HE}$, Schilte AF, et al. Effectiveness of reattribution for somatisation in general practice; a randomised controlled trial. submitted 2001. 
Chapter 9

Summary 
Chapter one describes the general background, origin and motivation of this thesis. Building on the findings of Portegijs' earlier study and on the literature on disclosure interventions, a rationale for a disclosure intervention for general practice (GP) somatisation is described.

In chapter two the distribution of workload in general practice in the Netherlands is assessed, as well as the contribution to workload of patient health problems and visiting patterns in previous years. One-fifth of the patients accounted for $50 \%$ of the GP's time, and half consumed $80 \%$. This distribution is remarkably similar to reports from other countries with different health care systems. In a regression model sociodemographic variables explained $9 \%$ of the variance in consultation rates, health problems explained another $11 \%$, and attendance in previous years an additional $11 \%$. Differences between practices were marginal. Two-thirds of the variance in patient attendance remained unexplained by the variables under study. Further research on the role of psychosocial factors on patient attendance is recommended.

The relation between the GP's clinical judgement of somatisation and a somatisation research instrument (SSI $5 / 5$, using DSM-III-R criteria) is investigated in chapter three, including how both operationalisations of somatisation are related to other important sociodemographic, medical, and communication variables. In 14 general practices, 407 frequently attending patients answered a questionnaire on somatisation symptoms, while the GPs gave their judgement on somatisation and communication for each patient. Other variables were extracted from the registered health status of the patients. We found a weak association (correlation: 0.27 ) between the GP's judgement and the DSM-III-R research instrument; however, relations with other variables showed that both operationalisations were quite similar constructs. The research instrument incorporated more psychological problems (depression and anxiety), while the GP's judgement of somatisation was influenced more strongly by attendance rate and by aspects of communication with the patient. For research addressing somatisation in primary care as a practical clinical problem, the operationalisation of somatisation should include not only an instrument like the SSI, but the clinical judgement of the practitioner as well, thereby widening the focus from comorbid mental disturbances to communication aspects.

In chapter four medical and psychosocial indicators of childhood adversity are identified in somatising patients in primary care, through retrospective questionnaires and interviews of 374 somatising frequent attenders in 27 general practices. The questionnaire on childhood problems showed acceptable validity against a structured interview of 77 patients (correlation 0.69); however, abuse 
was underreported in the questionnaire. Four out of five patients reported one or more major childhood problems. Childhood adversity was indicated independently by patients' chronic difficulties in relations and by genital-sexual symptoms. When GPs want to apply a more active approach towards somatisers they may show interest in the patient's childhood and life story, especially when patients are known to have chronic difficulties in relations and genital-sexual symptoms.

In chapter five a disclosure intervention for general practice is introduced and illustrated in three case histories. The patient told his or her story to a disclosure GP in two sessions, which was then followed by a joint consultation with the patient's GP.

Chapter six reports the outcome of a randomised controlled trial in 161 frequently attending somatisers in ten general practices. Patients in the intervention group were visited two to three times and were invited to disclose on emotionally important events in their life. Patients filled in questionnaires at 6, 12 and 24 months follow-up on the main outcome variables: medical consumption (medication and health care visits), subjective health and sick leave. Both groups were comparable at baseline, and 137 patients (85\%) completed the trial. No effect of the intervention was found on main outcome measures at different moments of follow-up, although a positive effect of disclosure cannot be completely ruled out, since confidence intervals were wide. Patients often had a depression or anxiety disorder for which they were not receiving adequate care. Though well received by patients and their GPs, the disclosure intervention did not show an effect in somatising patients in general practice.

Chapter seven describes the natural course of somatisation in general practice, and studied predictors of subjective health, sick leave and medical consumption in a two-year interval in 376 somatisating patients in 27 general practices. Overall, outcome measures were stable in the total group of somatising patients over the two years. Chronic difficulties and life events were strong crosssectional indicators of outcome. Only social support had an independent longterm effect on outcome, increasing over time. We are far from being able to predict which patients become progressively disabled or dependent on health care among patients with a chronic tendency of somatisation. When selecting somatising patients who need treatment most, GPs should focus on patients with impaired subjective health and high medical consumption, especially those who lack social support.

In chapter eight the results of this thesis are combined and commented. The methodological consequences of selecting patients at risk of somatisation are 
discussed. The design, withdrawal rate and follow-up time in the trial do not raise questions about the quality of our results, although we may have missed a modest short-lived effect of the disclosure intervention. We can not say much about a disclosure intervention applied by the patient's own GP, or a more sustained intervention. The positive experience of the author of this thesis with disclosure in his own practice, on more qualitative aspects of communication between doctor and patient, are discussed.

Key recommendations of this thesis are: further effectiveness studies of disclosure in specific target groups, a critical appraisal of other therapeutic techniques for somatisation in general practice, such as reattribution, and qualitative studies on the role of disclosure and aspects of communication between patients and their GPs. 
Hoofdstuk 10

Samenvatting 
Enkele belangrijke termen in dit proefschrift worden hier eerst uitgelegd. Daarna wordt de inhoud van de verschillende hoofdstukken samengevat.

De term somatisatie is afgeleid van het Griekse woord soma (lichaam) en verwijst naar de situatie waarin een patiënt vaak en met veel verschillende lichamelijke klachten artsen bezoekt, zonder dat lichamelijke ziekten een verklaring vormen voor de klachten. Bij somatisatieklachten wordt vaak een verband gelegd met psychische en sociale problemen in het heden en verleden. De dikke van Dale vermeldt dan ook bij somatisering "het lichamelijk uiten van psychische klachten." De meeste mensen herkennen het fenomeen uit eigen ervaring: spanning, drukte en emoties worden vaak lichamelijk gevoeld, bijvoorbeeld in hoofd- en nekpijn, hartkloppingen of menstruatieklachten. Deze lichamelijke kanten van emoties komen ook tot uiting in sommige spreekwoorden: een pak van mijn hart, er de kriebels van krijgen, hij heeft veel op zijn schouders, het gaat hem dun door de broek.

Aanvankelijk werd de term somatisatie met name in de psychiatrie gebruikt in de vorm van een somatisatiestoornis, verwijzend naar een invaliderend patroon van vele somatisatieklachten (minimaal twaalf) waarvoor geen lichamelijke ziekte als oorzaak kon worden aangewezen. De laatste decennia is het begrip somatisatie ook in de huisartsgeneeskunde in zwang geraakt voor patiënten met tussen de vijf en de twaalf klachten van een lijst van 37 omschreven somatisatieklachten. Een somatisatiestoornis, met meer dan twaalf klachten, komt in de huisartspraktijk maar zelden voor.

Het begrip psychosomatisch dient onderscheiden te worden van somatisatie. Psychosomatisch duidt op lichamelijke afwijkingen die door psychisch lijden worden opgewekt, zoals bijvoorbeeld een maagzweer of een astma-aanval ten gevolge van stress. Het verschil met somatisatie is dat er bij psychosomatische aandoeningen wel degelijk lichamelijke afwijkingen gevonden worden, zoals een zweer of een ontstekingsreactie.

Onder Nederlandse huisartsen is verder het begrip somatische fixatie gebruikelijk, duidend op een versmalling van de communicatie tussen patiënt en arts tot een puur medisch-lichamelijke, terwijl psychosociale aspecten op de achtergrond een belangrijke rol vervullen.

In hoofdstuk één wordt de algemene achtergrond en doelstelling van het proefschrift beschreven. Gebruik makend van de eerdere studie van Portegijs en van de literatuur over de disclosure methode wordt de disclosure behandeling in de huisartspraktijk onderbouwd.

In hoofdstuk twee wordt onderzocht hoe de verdeling is van de tijd die de huisarts per patiënt besteedt in Nederland. Verder wordt onderzocht hoeveel gezondheidsproblemen en bezoekpatronen van patiënten in eerdere jaren 
bijdragen aan de consultfrequentie van patiënten. Eénvijfde van de patiëntenpopulatie neemt de helft van de tijd van de huisarts voor haar rekening en de helft van de patiëntenpopulatie legt beslag op viervijfde van de spreekuurtijd. Deze verdeling lijkt sterk op die in andere landen met andere gezondheidszorgsystemen. In een regressiemodel blijkt dat de consultfrequentie voor $9 \%$ door sociaaldemografische factoren kan worden verklaard; gezondheidsproblemen beslaan $11 \%$ en bezoekpatronen in eerdere jaren verklaren nog eens $11 \%$. Verschillen tussen praktijken dragen haast niets bij. In totaal blijft tweederde van de variantie onverklaard en verdere studie naar de rol van psychosociale factoren op consultfrequentie wordt voorgesteld.

De relatie tussen de huisartsenbeoordeling somatisatie en een gevalideerde somatisatievragenlijst voor patiënten wordt onderzocht in hoofdstuk drie. Ook wordt nagegaan hoe beide definities van somatisatie zich verhouden tot belangrijke andere variabelen, zoals sociaaldemografische gegevens, gezondheidsproblemen en communicatieproblemen tussen huisarts en patiënt. In negen huisartspraktijken beantwoorden 407 veelkomers een vragenlijst over somatisatiesymptomen; tegelijkertijd vermelden de huisartsen of ze vinden dat patiënten somatiseren en hoe ze vinden dat de communicatie met de patiënten loopt. Andere variabelen worden via het Registratie Netwerk Huisartspraktijken uit het electronisch medisch dossier betrokken. Het huisartsenoordeel en de somatisatievragenlijst voor patiënten vertonen slechts een geringe samenhang (correlatie van 0,27 ), maar de verbanden tussen beide definities van somatisatie en de andere belangrijke variabelen lijken sterk op elkaar. Een verschil is dat de somatisatievragenlijst meer patiënten selecteert met psychologische problemen, zoals depressie en angst, terwijl volgens het oordeel van de huisartsen somatiseren samenhangt met de consultfrequentie van patiënten en met communicatieproblemen tussen arts en patiënt. Onderzoek naar somatisatie in de eerste lijn zou aan de patiëntenvragenlijst het oordeel van de huisarts moeten toevoegen, om zodoende naast psychische problemen ook communicatieaspecten erbij te betrekken.

In hoofdstuk vier worden medische en psychosociale indicatoren van een ongunstige jeugd opgespoord, door middel van retrospectieve vragenlijsten en interviews bij 374 somatiserende veelkomers in 27 huisartspraktijken. De vragenlijst naar jeugdproblemen heeft een acceptabele validiteit ten opzichte van een gestructureerd interview bij 77 patiënten (correlatie 0,69). Fysiek geweld en seksueel misbruik worden echter minder goed gerapporteerd in de vragenlijsten. De meeste somatiserende patiënten (80\%) rapporteren één of meer grote problemen in hun jeugd. Indicatoren van een ongunstige jeugd zijn chronische moeilijkheden in relaties op volwassen leeftijd en genitale of seksuele symp- 
tomen. Indien huisartsen zich actiever willen opstellen ten opzichte van somatiserende patiënten kunnen ze interesse tonen in het levensverhaal en de jeugd van patiënten, met name indien patiënten langdurige sociale moeilijkheden hebben of genitale en seksuele symptomen rapporteren.

Hoofdstuk viifbeschrijft de disclosure behandeling voor de huisartspraktijk en deze wordt geillustreerd door middel van drie casusbeschrijvingen. De patiënten onthullen in twee sessies hun levensverhaal aan de disclosure huisarts van het onderzoek, gevolgd door een gezamenlijk gesprek met hun eigen huisarts en de disclosure huisarts.

In hoofdstuk zes wordt de uitkomst van het gerandomiseerd gecontroleerde experiment beschreven, waaraan 161 veelkomende somatiserende patiënten in tien praktijken hebben deelgenomen. De interventiepatiënten werden in twee tot drie gesprekken uitgenodigd emotioneel belangrijke gebeurtenissen in hun leven te onthullen. Bij start van de studie en na 6, 12 en 24 maanden vulden de deelnemende patiënten vragen in over medicijngebruik, bezoeken aan hulpverleners, hoe ze hun eigen gezondheid inschatten en hoe vaak ze zich ziek gemeld hebben. De interventie- en controlegroep waren vergelijkbaar bij aanvang van de studie en 137 patiënten (85\%) voltooiden de studie. Er wordt geen effect van de disclosure gesprekken gevonden op de uitkomstmaten op de verschillende meetmomenten, alhoewel een positief effect van disclosure niet geheel kan worden uitgesloten. Veel patiënten hebben een depressie of angststoornis, waarvoor ze vaak niet de juiste behandeling ontvangen. Alhoewel het oordeel van patiënten en huisartsen over het nut van de behandeling positief is, laat de disclosure behandeling geen positief effect zien op harde uitkomstmaten bij somatiserende patiënten in de eerste lijn.

In hoofdstuk zeven wordt het natuurlijk beloop van somatisatie in de huisartspraktijk beschreven gedurende een periode van twee jaar. Verder wordt er in dit hoofdstuk gekeken of het beloop van somatisatie kan worden voorspeld door stressfactoren. De uitkomstmaten (medicijngebruik, bezoeken aan hulpverleners, subjectieve gezondheid en ziekteverzuim) blijven stabiel in de 376 somatiserende patiënten over twee jaar. Chronische moeilijkheden en levensgebeurtenissen zijn goede maten hoe het met patiënten is op datzelfde moment, maar voorspellen haast niet hoe het met de patiënten gaat na één tot twee jaar. Alleen de factor sociale steun voorspelt hoe het met de patiënten gaat in de eerste twee jaar. Als huisartsen een selectie willen maken welke somatiserende patiënten dringend behandeling nodig hebben, kunnen ze zich het beste richten op patiënten die hun gezondheid als slecht ervaren, een hoog medicijngebruik hebben en vooral die patiënten die weinig sociale steun ervaren. 
In hoofdstuk acht worden de resultaten van de verschillende hoofdstukken gecombineerd en van commentaar voorzien. De methodologische consequenties van onze selectieprocedure van risicopatiënten voor somatisatie in plaats van patiënten die op dat moment een somatisatieklacht presenteren, worden besproken. De vorm van het onderzoek, het uitvalpercentage en de looptijd van de studie doen geen vragen rijzen over de kwaliteit van onze resultaten, alhoewel we een initieel kortdurend effect (verergering of verbetering) van de disclosure behandeling gemist kunnen hebben. We kunnen geen uitspraak doen over een langer aanhoudende disclosure behandeling, eventueel uitgevoerd door de eigen huisarts. Tenslotte wordt de positieve ervaring van de auteur van dit proefschrift besproken met disclosure in zijn eigen praktijk op meer kwalitatieve aspecten, zoals communicatie tussen arts en patiënt.

De belangrijkste aanbevelingen van dit proefschrift zijn: toekomstige studies naar het effect van disclosure in speciale groepen en een kritische beoordeling van het effect van andere therapieën bij somatisatie, zoals de re-attributie techniek. Ook worden kwalitatieve studies naar de rol van disclosure en communicatie-aspecten tussen arts en patiënt voorgesteld. 



\section{Appendix A}

\section{GENERAL PRACTITIONERS PARTICIPATING IN THE STUDY}

- Huisartsenmaatschap Mauritsweg 3a, Stein; R. Leclercq, J. van Proosdij, G. Govaert en G.J. Dinant

- Huisartspraktijk Meerssenerweg 142, Maastricht; V. Zwietering

- $\quad$ Gezondheidscentrum Akerstraat Noord 74, Hoensbroek;

M. van Nunen, B. Bruls, P. Voorhoeve, R. Helmers, H. Paas, G.J. van Schendel $f$, P. van Dijk

- Medisch Centrum Putstraat 32, Landgraaf; H. Ypma, J. Eussen, C. Stuurman

- Huisartsenpraktijk Grote Schuur, Kasteellaan 17, Well; H. Schönberger, J. van Putten, W. van den Broek

- Huisartspraktijk Vlotstraat 7, Heerlen; B. de Wit

- Huisartsenpraktijk Raadhuisplein 4, Voerendaal; R. Panhuysen, P. Hulshof, R. Costongs

- Huisartsenpraktijk Veldhofstraat 26, Eygelshoven; V. Kaiser, J. Veldhuizen

- Huisartspraktijk St. Rochusstraat 13, Kerkrade; H. van der Ploeg

- Huisartsenpraktijk Kapelweg 54, Kerkrade; F. Soomers, J. Soomers-Turlings, J. Stoffers 


\section{Appendix B}

\section{PATIENT QUESTIONNAIRE ON MAIN OUTCOME VARIABLES}

\section{UW KLACHTEN}

1 Welke klacht of klachten heeft $\mathrm{u}$ de afgelopen maand gehad? (bij meer klachten: belangrijkste drie klachten noemen)

Kunt $\mathrm{u}$ in een paar woorden opschrijven wat u precies voelt als $\mathrm{u}$ last heeft van de klacht.

le klacht:

2e klacht:

3e klacht:

De volgende vragen gaan over de klachten die $u$ in vraag 1 over de afgelopen maand heeft genoemd.

2 Wat is volgens u de oorzaak van de klachten?

1e klacht:

2e klacht:

3e klacht:

3 Hoeveel invloed hebben uw klachten de afgelopen maand op de volgende onderdelen van uw dagelijks leven (zet voor ieder onderwerp een kruisje op de lijn):

3a uw werk:

$\begin{array}{lll}\text { helemaal niet heel sterk } & \end{array}$

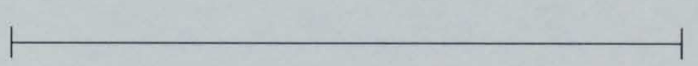

3b uw slaap:

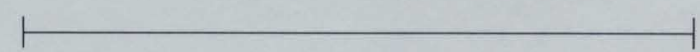


3c sport/lichaamsbeweging:

helemaal niet

heel sterk

$$
\text { 1 }
$$

$3 d$

omgang met familie en vrienden:

helemaal niet

heel sterk

$$
1
$$

3e uw stemming:

helemaal niet

heel sterk

|

4 Zit u veel over uw klachten te denken of te piekeren?

helemaal niet

heel sterk

5a Zoals mensen een idee kunnen hebben over de kwaliteit van dingen, zo kunnen ze ook een idee hebben over de kwaliteit van hun leven. Deze kan goed of slecht zijn of er ergens tussen in. Wilt $u$ op de lijn hieronder aangeven waar $u$ vindt dat nu de kwaliteit van uw leven ligt.

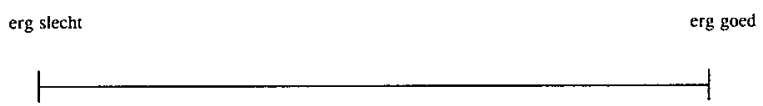

5b Was de kwaliteit van uw leven 6 maanden geleden slechter of beter dan nu?

veel slechter

$$
\text { veel beter }
$$<smiles>C1CC1</smiles> 
6a Wilt $\mathrm{u}$ op de lijn hieronder aangeven hoe gezond u zich de afgelopen maand voelde. Het gaat om de gezondheid zoals u die ervaart.

niet gezond

heel gezond

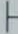

$6 \mathrm{~b}$ Was uw gezondheid zoals u die ervaart 6 maanden geleden slechter of beter dan nu?

veel slechter

veel beter

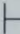

De volgende vragen gaan over de afgelopen 6 maanden

7a Bent $\mathrm{u}$ in de afgelopen 6 maanden met nieuwe aktiviteiten begonnen?

Zo ja, met wat:

$\square$ sport, welke:

$\square$ hobby, welke:

$\square$ werk, welk:

$\square$ cursus/opleiding

$\square$ niet met nieuwe aktiviteiten begonnen

7b Bent $\mathrm{u}$ in de afgelopen $\mathbf{6}$ maanden met nieuwe aktiviteiten gestopt, zoals sport, studie, hobbies, interessen of werk?

Zo ja, met wat:

$\square$ sport, welke:

$\square$ hobby, welke

$\square$ werk, welk:

$\square$ cursus/opleiding:

$\square$ niet met aktiviteiten gestopt 
8 Bent u de afgelopen 6 maanden bij de volgende hulpverleners geweest en hoeveel keer bent $\mathbf{u}$ er geweest? (als de hulpverlener bij u kwam telt dat ook mee).

$\square$ eigen huisarts:

..... keer

$\square$ andere huisarts:

..... keer

$\square$ medisch specialist, welk specialisme?

$$
1 . .
$$

2.

3.

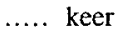

..... keer

$\square$ fysiotherapie, mensendieck- of cesartherapie

..... keer

$\square$ dietiste:

..... keer

$\square$ maatschappelijk werk:

..... keer

$\square$ psycholoog, psychotherapeut of RIAGG:

..... keer

$\square$ alternatieve genezer, welke:

keer

$\square$ andere hulpverlener, welke:

..... keer

$\square \quad$ niet bij hulpverleners geweest

9 Hoeveel weken heeft $\mathrm{u}$ de afgelopen 6 maanden niet gewerkt wegens ziekte (huishouden telt ook als werk)?

weken

10 Welke medicijnen heeft $\mathrm{u}$ de afgelopen 6 maanden gedurende een periode langer dan een week gebruikt? Alle medicijnen tellen mee, ook die u zelf gekocht heeft. Indien $u$ zich de naam van het middel niet herinnert, schrijft $u$ dan op waarvoor $u$ het gehad heeft.

$\square \quad$ kalmeringsmiddelen:

$\square \quad$ slaapmiddelen:

$\square \quad$ pijnstillers:

$\square$ vitamines:

$\square$ homeopatische middelen:

$\square \quad$ andere middelen: 


\section{Appendix C}

\section{STUDY PROFILE: PATIENTS PER CHAPTER}

M A A S S T R I C H T

(15 practices)

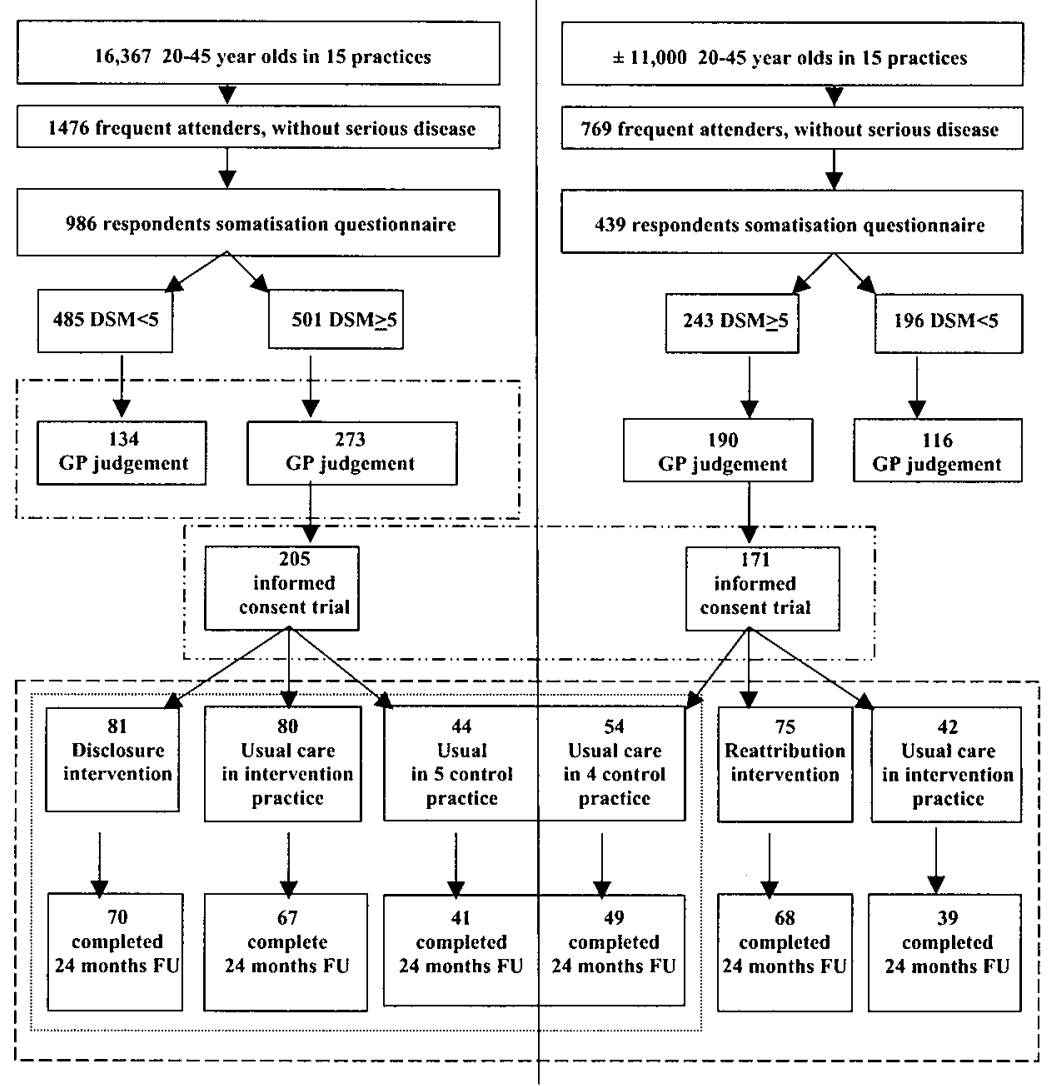

$=$ population used in chapter 3 (clinical judgenent and standardised measurement compared; $\mathrm{N}=407$ )

$=$ population in chapter 4 , two patients dropped out (indicators of childhood adversity; $N=374$ )

= population used chapter 6 (RCT on diclosure intervention; $\mathrm{N}=161+98$ )

$=$ population used in chapter 7 (clinical course and predictive value of stress factors; $N=376$ )

In chapter 2 (workload determinants; $N=2957$ ) data from another study on multimorbidity were used 


\section{Dankwoord}

Allereerst wil ik hier de patiënten bedanken die aan het onderzoek hebben deelgenomen. Zonder het vertrouwen dat zij in ons stelden, waarbij ze ook nog eens de helft kans liepen uitgeloot te raken voor de disclosure behandeling, had het onderzoek niet kunnen plaatsvinden. Door de levensverhalen van al deze mensen ben ik langzaam meer gaan begrijpen van somatisatie. Dat deze patiënten trouw alle lange vragenlijsten terugstuurden heeft bijgedragen aan het succes van de studie.

De andere essentiële poot van het onderzoek waren de deelnemende huisartsen: G. Govaert, R. Leclercq, G.J. Dinant, J. van Proosdij; V. Zwietering; M. van Nunen, B. Bruls, P. Voorhoeve, H. Zwanikken; H. Paas, R. Helmers, G.J. van Schendel †, P. van Dijk; J. Eussen, H. Ypma, C. Stuurman; H. Schönberger, J. van Putten, W. van den Broek; B. de Wit; R. Panhuysen, P. Hulshof, R. Costongs; V. Kaiser, J. Veldhuizen; H. van der Ploeg; F. Soomers, J. Soomers-Turlings en J. Stoffers. Bedankt voor jullie inzet!

Piet Portegijs heeft dit onderzoek in het leven geroepen. De studie die jij verrichtte tussen 1989 en 1996 resulteerde in een NWO projectaanvraag voor een interventiestudie, die werd gehonoreerd. Ik herinner me nog dat je me min of meer uit de verbouwing van ons huis wegplukte om bij de vakgroep aan dit project te komen werken. Wat de doorslag gaf was dat je het als een voordeel zag dat ik als klassiek homeopaat gewend was lang te luisteren naar de verhalen van mensen. Zonder jouw dagelijkse begeleiding had ik het bijltje er in de beginjaren vast bij neergegooid. Over het onderzoek konden we niet alleen bij de capaciteitsgroep, maar ook tijdens het dakbranden, traplassen, slopen en kazemattengraven flinke windmolens opzetten. Piet, je humor, enorme energie, positivistische houding en het vermogen mij op de juiste momenten met rust te laten zijn belangrijke stimuli geweest.

André Knottnerus, met je ervaring en weloverwogen, rustige aanpak stuurde je op cruciale momenten het project door moeilijke fasen. Enerzijds heb je altijd geduld gehad, anderzijds wist je precies waar je met ons op afstevende. Alleen afspraken maken was bijna een onmogelijkheid, dat kon alleen drie 
maanden vooruit; een teken dat je voor vele mensen een zelfde belangrijke functie vervult.

Monique Latour, mijn onderzoeksassistent gedurende de eerste drie jaar. Het was een tegenvaller dat je geen gesprekken met patiënten mocht voeren. Liever kreeg je uitdagende taken, maar die waren niet altijd voorhanden. Jij hebt het systeem aangebracht in de dataverzameling en het grootste deel van de dataverwerking voor je rekening genomen. Onze presentaties in Mallorca vond ik een geweldige afsluiting van onze samenwerking.

Nettie Blankenstein, onderzoeker voor het zusterproject in Amsterdam. Onze vergaderingen en vele telefoongesprekken waren de leukste en nuttigste momenten van het project. Hoofd- en bijzaken scheidend, met veel humor en altijd iets lekkers erbij met een oud zakmes gesneden. Nog altijd teer ik op de paar kilo "witte suiker" die je voor mij op slimme wijze uit de handen van de douane hield! Ook trok je ons eerste artikel, dat op een dood spoor was beland, met enkele puntige opmerkingen weer vlot, terwijl alle anderen hun kruit al verschoten hadden. Dat was voor mij een keerpunt in het wetenschappelijk schrijven.

Marjan, bij jou kon ik goed even stoom afblazen en broeden op een combinatie van onze beide projecten, wat uiteindelijk leidde tot een hoofdstuk in dit proefschrift.

Verder wil ik hier nog een hele reeks mensen bedanken die allemaal een onmisbare bijdrage leverden: Joost, Henriëtte, André van Loenen, Jacques en Marten in Amsterdam; Petra van den Berg als disclosure arts; Hubert Schouten en Arnold Kester voor statistisch advies; Frenk Peeters als psychiater; Susan Cowan en Truus voor het correctiewerk van het proefschrift; Mehtab, Ibti, Osnad, Melina, Shyam en Mohsen voor hun hulp bij het ontwerp van de kaft; de mede-weekendwerkers: Mark, Regina, Harrie, Frans en Sylvia; het RNH en Memic: Job, Alfons, Hans, Gertie en Gregor; mijn kamergenoten: Margreet, Henriëtte, Willy, Berna en Marie-Louise; de vaste EGPR W-gangers: Jan-Joost en Saskia; tot slot alle andere behulpzame vakgroepmensen, met name: Ine, Frits, Hannie, Jos, Jim, Paddy, Marga, Anne-Marie, Paula, Karin, Marlies en Linda.

Naast het werk bij gezondheidscentrum Dr. van Kleef had ik de ruimte om aan het onderzoek te werken. Bedankt alle van Kleefjes: Paul, Pie, Mieke, Bèr, Bianca, Linda, Riet, Lia, Cathy, Sylvia, Truus, Lilian, Karin, Iris en Jeanine. Ook dank aan Peter Schröder, bij wie ik twee jaar in de praktijk werkte. Mijn huidige collega's Rien Heijnen en Pascal Meijer, jullie zijn mijn paranimfen bij de promotie en in de praktijk. Speciaal bedankt aan Joyce Slijpen, mijn geweldige assistente, die me bijstond met veel thee als ik vermoeid van het typen toch 's morgens spreekuur moest doen en Nancy Brandts, Joyce Jaspers en Elly 
Godding in ons nieuwe team. Ook dank aan José voor alle hartelijke hulp aan het thuisfront.

De belangrijkste mensen volgen aan het einde van dit dankwoord. In de allereerste plaats bedank ik mijn lieve ouders, die mijn studie stimuleerden, me altijd vrij hebben gelaten en me een belangrijke eigenschap meegaven: eigenwijsheid. Mijn zussen Lydia en Oda en hun partners Bert en Heiko: ook al wonen we nu een eind uit elkaar, onze basis is gemeenschappelijk.

Een speciaal woord van dank aan Swami Shyam in India, die mij inspireert en van wie ik leer hoe ik me wijsheid eigen makk.

Vera, Guido en Wim, mijn maatjes in huis waarmee ik lief en leed deel en Joep en Mia als warme schoonouders, bedankt.

Ook wil ik alle vrienden noemen die me hebben moeten missen omdat ik zo nodig jarenlang hard wilde werken: Hannie, Eva, Daniël en Megan, Melina en Barth, Linda en Hans, Miek en Rajiv, Erik en Loes, Peter en Lisanne, Pim en Maria, Willem en Elsbeth, en de KURC: Maarten en Heinz-Joseph, Jaap en Andrea, Mario en José, Michiel en Monique. We hebben heel wat uren samen in te halen.

Tenslotte mijn liefste Truus, die het hele traject van werk, onderzoek, reizen en ons leven aan de Brusselsestraat met me deelde en me veel heeft moeten missen ten bate van dit onderzoek. Je hebt de vlag uitgehangen toen het manuscript af was. Vandaag gaan we het eindelijk vieren! 



\section{Curriculum vitae}

Bert Schilte werd geboren op 26 december 1962 te Roermond en volgde zijn middelbare school (Atheneum B) aan het Bisschoppelijk College Schöndeln in Roermond. Daarna studeerde hij een jaar aan de Kansas University in de Verenigde Staten en van 1982 tot 1989 studeerde hij geneeskunde aan de Universiteit Maastricht. Na een kortdurende aanstelling bij de vakgroep Huisartsgeneeskunde aan de Universiteit Maastricht, werkte hij negen maanden voor Artsen Zonder Grenzen in een afgelegen gebied in Afghanistan. Hierna doorliep hij de tweejarige huisartsenopleiding in de groepspraktijk te Voerendaal met als opleider Rudolph Panhuysen. Na een periode van waarnemingen in verschillende praktijken en nogmaals een uitzending voor Artsen Zonder Grenzen naar Bosnië, werkte hij vijf jaar twee dagen per week als huisarts in Gezondheidscentrum Dr. van Kleef in Maastricht. Daarnaast werkte hij gedurende twee jaar een dag per week als klassiek homeopaat. In april 1996 startte hij voor drie dagen per week bij de vakgroep Huisartsgeneeskunde met het onderzoek dat tot deze promotie heeft geleid. In juli 1999 nam hij de huisartspraktijk van Joop Tromp te Maastricht over en vanaf februari 2001 vormt hij samen met de huisartsen Rien Heijnen en Pascal Meijer een maatschap in de wijk Caberg in Maastricht. Bert is getrouwd met Truus Breukers. 